\title{
Redescription of the type species of Odontostilbe Cope, 1870 (Teleostei: Characidae: Cheirodontinae), and description of three new species from the Amazon basin
}

\author{
Cristina M. Bührnheim*,** and Luiz R. Malabarba*,***
}

The widespread Neotropical cheirodontine Odontostilbe fugitiva is reviewed, and three new species of the genus are described from the Amazon basin. A neotype is designated for O. fugitiva, from the mouth of the río Mazán, upper río Amazonas basin, Peru. Three nominal species are herein considered as synonyms of $O$. fugitiva: $O$. madeirae, $O$. drepanon, and $O$. caquetae. The three new species are respectively $O$. ecuadorensis from the río Napo basin, $O$. nareuda from the rio Madeira basin, and $O$. parecis from the rio Guaporé basin (rio Madeira basin). Among other diagnostic characters, gill rakers are especially informative in distinguishing species. Description of gill raker denticulation is provided for the first time for species of the Cheirodontinae. Secondary sexually dimorphic characters are described for all species.

O queirodontíneo neotropical Odontostilbe fugitiva, de ampla distribuição, é revisado e três espécies novas são descritas para o gênero na bacia Amazônica. Um neótipo é designado para O. fugitiva, da boca do rio Mazán, alto rio Amazonas, Peru. Três espécies nominais são consideradas sinônimas de $O$. fugitiva: $O$. madeirae, $O$. drepanon e $O$. caquetae. As três espécies novas são, respectivamente, $O$. ecuadorensis da bacia do rio Napo, $O$. nareuda da bacia do rio Madeira e $O$. parecis da bacia do rio Guaporé (bacia do rio Madeira). Entre outros caracteres diagnósticos, os rastros branquiais são especialmente informativos para distinguir as espécies. Uma descrição da denticulação dos rastros branquiais é apresentada pela primeira vez para espécies de Cheirodontinae. Caracteres de dimorfismo sexual secundário são descritos para todas as espécies.

Key words: Neotropical, Neotype, Systematics, Odontostilbe madeirae, Odontostilbe drepanon, Odontostilbe caquetae.

\section{Introduction}

The Cheirodontinae contains about 15 genera and 47 species of small Neotropical characid fishes, usually attaining $30-$ $40 \mathrm{~mm}$ in standard length (Malabarba, 2003; Malabarba et al., 2004). Odontostilbe Cope, 1870 was originally defined based on the presence of a complete lateral line, versus interrupted in Cheirodon Girard, 1855. The genus initially comprised only Odontostilbe fugitiva Cope, 1870 from "Pebas, Eastern Equador". Currently, Pebas is a city in the Departamento de Loreto in Peru, not Ecuador. The taxonomic history of the discussion of the validity of Odontostilbe versus Cheirodon dates back to the work of the danish zoologist Christian F. Lütken. While redescribing Poecilurichthys pulcher Gill, 1858, Lütken (1875: 236-237) noted that "technically the species of Trinidad is properly an Odontostilbe Cope, but this genus only differs from the known [Chirodon] G. in the lateral line which is not complete ..." [our translation], referring the species as Chirodon (Odontostilbe) pulcher (Gill, 1858). Subsequently, Steindachner (1882a, 1882b) described Chirodon pequira, and designated the type species of Odontostilbe as Chirodon (Odontostilbe) fugitiva. Subsequent works alternated usage of Odontostilbe as valid (e.g. Eigenmann \& Eigenmann, 1892, in a preliminary list of freshwater fish of South American listed Odontostilbe fugitiva and recognized Odontostilbe pulcher), or as synonym of Cheirodon (e.g. Ulrey, 1895, when examining "Characinidae" collected by Charles F. Hartt in Brazil listed Cheirodon fugitiva and Cheirodon pulcher, along with five other species of Cheirodon).

Retaining the original diagnostic character of lateral line complete, Eigenmann (1915) recognized Odontostilbe with eight species, included in his new subfamily Cheirodontinae:

*Museu de Ciências e Tecnologia, PUCRS, Av. Ipiranga, 6681, P. O. Box. 1429, 90619-900 Porto Alegre, RS, Brazil.

**Universidade Federal do Amazonas, ICB, Lab. Zoologia, Av. Gen. Rodrigo Otávio Jordão Ramos, 3000, 69077-000 Manaus, AM, Brazil. e-mail: cmbuhrn@yahoo.com.br

*** Departamento de Zoologia, Universidade Federal do Rio Grande do Sul, Av. Bento Gonçalves, 9500, bloco IV, prédio 43435, $91501-970$ Porto Alegre, RS, Brazil. e-mail: malabarb@ufrgs.br 
O. fugitiva, O. drepanon Fowler 1913, O. madeirae Fowler 1913, O. microcephala Eigenmann, 1907, O. paraguayensis Eigenmann \& Kennedy, 1903, O. pulchra, O. hastata Eigenmann, 1913, and O. melandeta Eigenmann, 1912. Eigenmann (1915), however, further indicated that $O$. hastata, and $O$. melandeta would be probably moved to other genera. In fact, $O$. hastata was afterwards moved into the genus Saccoderma (Schultz, 1944), and O. melandetum into the genus Aphyocharacidium (Géry, 1960). Subsequent alternate views on the validity of Odontostilbe versus Cheirodon based on the completeness of lateral line were presented by Fink \& Weitzman (1974), who considered Odontostilbe as a synonym of Cheirodon, and by Fowler (1913, 1940, 1943), Böhlke (1954), and Géry (1964, 1972a, 1972b, 1977), who considered Odontostilbe as valid. Uj (1987) proposed a new diagnosis for Odontostilbe versus Cheirodon based on some osteological characters and included a rearrangement of some species of both genera, but his hypothesis was not accepted by subsequent studies (e.g. Malabarba, 1998, 2003).

Since the establishment of the monophyly of Cheirodontinae and the proposal of a phylogenetic diagnosis of all included genera (Malabarba, 1998), Odontostilbe is considered valid with Holoshesthes Eigenmann, 1903 as a synonym. Cheirodon Girard, 1855 was restricted to six species from southern South America, and included in the tribe Cheirodontini. Six new genera were proposed, and a new tribe Compsurini was proposed. However, Odontostilbe and four other genera were left incertae sedis in Cheirodontinae. More recently, Malabarba (2003) refers ten species to Odontostilbe: O. dialeptura (Fink \& Weitzman, 1974), O. fugitiva, O. gracilis Géry, 1960, O. littoris Géry, 1960, O. microcephala, O. mitoptera (Fink \& Weitzman, 1974), O. paraguayensis, O. pequira, and $O$. roloffi Géry, 1972. Two of them from Central America, O. mitoptera and $O$. dialeptura, were temporarily referred to Odontostilbe, because both were found to be inseminators, thus belonging to the tribe Compsurini (Malabarba \& Weitzman, 1999, 2000).

Herein we provide a redescription of the type species of Odontostilbe, O. fugitiva, including the designation of a neotype, a discussion of its synomyms, and morphological variation of populations across the Amazon basin. In order to present a better diagnosis for the type-species of the genus, we also describe herein three new species putatively related to $O$. fugitiva from major tributaries of the Amazon basin, one from upper río Napo and río Putumayo, in Ecuador, and two from rio Madeira basin, in Brazil and Peru. This is part of a major systematic study of Odontostilbe.

\section{Material and Methods}

Counts and measurements follow Fink \& Weitzman (1974), primarily on the left side of the specimen. Head length is the distance between the tip of the snout and the posterior end of subopercle, which is slight posterior to the margin of the opercle. Total vertebrae number includes the four vertebrae of the Webberian apparatus, and the terminal "half centrum" as outlined by Malabarba \& Weitzman (1999). The gill raker at the junction of the ceratobranchial and the epibranchial is referred as the posteriormost gill raker of the lower branch of the arch, and counted jointly with the gill rakers on the lower branch. Specimens were cleared and stained according Taylor \& Van Dyke (1985), and/or radiographs were used for counting vertebrae, teeth, and gill rakers. Scanning Electron Microscope (SEM) images were obtained from teeth and denticulation of gill rakers. Values of the holotypes and neotype of $O$. fugitiva are marked in bold in descriptions.

The following institutions provided material for the study: AMNH - American Museum of Natural History, New York, USA; ANSP - Academy of Natural Sciences, Philadelphia, USA; CAS - California Academy of Sciences, San Francisco, USA; CBF - Colección Boliviana de Fauna, La Paz, Bolívia; FMNH - Field Museum of Natural History, Chicago, USA; INHS - Illinois Natural History Survey, Illinois, USA; INPA Instituto Nacional de Pesquisas da Amazônia, Manaus, Brazil; KU - University of Kansas, Kansas, USA; MCP - Museu de Ciências e Tecnologia, Porto Alegre, Brazil; MCNG - Museo de Ciencias Naturales de Guanare, Guanare, Venezuela, MEPN - Museo de la Escuela Politénica Nacional, Quito, Ecuador; MHNG - Muséum d'histoire naturelle, Geneva, Switzerland, MNHN - Muséum d'historie naturelle, Paris, French; MPEG Museu Paraense Emílio Goeldi, Belém, Brazil; MUSM - Museo de Historia Natural de la Universidad Nacional Mayor de San Marcus, Lima, Peru; MZUSP - Museu de Zoologia da Universidade de São Paulo, São Paulo, Brazil; NRM (Naturhistoriska Riksmuseet) Swedish Museum of Natural History, Stockholm, Switzerland; ROM - Royal Ontario Museum, Toronto, Canada; UF - University of Florida, Gainsville, USA; USNM - National Museum of Natural History, Smithsonian Institution, Washington D.C., USA. Abbreviatures given along with the number of specimens are the following: $\mathrm{m}$ morphometrics and meristics; c - only meristics; $\mathrm{x}$ - meristics taken from x-rays; c\&s - cleared and stained specimens.

As demonstrated by Gonçalves et al. (2005) in the characid Aphyocharax, sexual dimorphism may start development at different body sizes, according to gonadal maturation, and so, body size itself does not allow assuming a given specimen lacking male sexually dimorphic features is a female. So, males and females are recognized only when dissected, or when showing sexual dimorphism in specimens of similar size in the same collecting lot. Specimens smaller than the smallest specimen showing sexual dimorphism in each lot are termed as unsexed. Specimens of any size belonging to lots where sexual dimorphism is absent are termed as unsexed.

Statistical analyses. Principal component analysis (PCA) was used to check overall variation among samples, looking for differences in morphometrics among species or between sexes, being an input to multiple regressions (Johnson \& Wichern, 1998). PCA on covariances of logarithmically transformed measurements were obtained using Past version 1.28 2004, and Sigma Plot version 6.10 2000. The first principal component was partitioned out, considering that it mostly accounts for 
size variation (Strauss, 1985).

Multiple linear regressions were applied to describe morphometric differences among species or between sexes. An "overall test for coincidental regressions" as described by Zar (1996: 368,431), and Souza (1998:72-77) was used to determine whether the regressions of two set of data are estimating two species or sexes (H1) or the same population regression (Ho). The test was applied when regression lines showed overlapping in confidence limits. The null hypothesis is that there is a single population underlying all $k$ regressions. The following formulae were used: $F=((\mathrm{SSR} 1$ - SSR2 / 2) / $(\mathrm{SSR} 2 /$ $\mathrm{n}-4)$ ), where $\mathrm{n}=$ number of $\mathrm{x}, \mathrm{y}$ cases, and $\mathrm{n}-4$ means the sum of the two residual degrees of freedom. The $\mathrm{F}$ value is obtained by calculating sum of squared residuals (SSR) of each linear regression of any two supposed different species (or between males and females) (SSRsp1+SSRsp2=SSR2), and the pooled sum of squared residuals (SSR1) obtained of a unique linear regression for the same data. The SSR $2<\mathrm{SSR} 1$ indicates two regression lines are better adjusted to the linear model. Considering two separated regression lines would better describe the function between dependent and independent variables of two hypothesized different species than an unique regression line for the same data, the F statistic would be higher than Fisher's F (alpha=0.05), rejecting Ho. Associated $\mathrm{p}$ values were obtained using a F-table.

\section{Results}

Odontostilbe fugitiva Cope, 1870

Fig. 1

Odontostilbe fugitiva Cope, 1870: 566 [original description; dentition figured; type locality: "Pebas, Eastern Equador", actually Pebas, Loreto, Peru, in the Ampiyacu-Amazonas drainage]. -Eigenmann \& Eigenmann, 1891: 54 [listed, Pebas, Villa Bella, Santarém]. -Eigenmann, 1910: 429 [listed, habitat: Ecuador (following Cope, 1870; currently Peru)]. Fowler, 1913: 529, 532 [comparison to $O$. madeirae and $O$. drepanon]. -Eigenmann, 1915: 90 [redescription based on specimens of San Antonio de rio Madeira, Amazon basin; erroneous distribution from Panama and Trinidad to La Plata and Peruvian Amazon; in key]. -Eigenmann \& Allen, 1942: 45, 265 [listed for the Amazon basin between lower Marañon, Pongo de Manseriche, to Tabatinga; annotated list in Pebas region, lower Marañon]. -Fowler, 1945a:134 [listed, Pebas, Peru]. -Fowler, 1948: 195 [listed, rio Amazonas, Brazil, Equador (following Cope, 1870; actually Peru)]. -Böhlke, 1954: 137-139 [listed, Odontostilbe fugitiva as possible synonym of Odontostilbe pulchra]. Géry, 1972a: 20-21 [O. caquetae Fowler, 1943, O. madeirae Fowler, 1914 and $O$. drepanon Fowler, 1914 as a probable

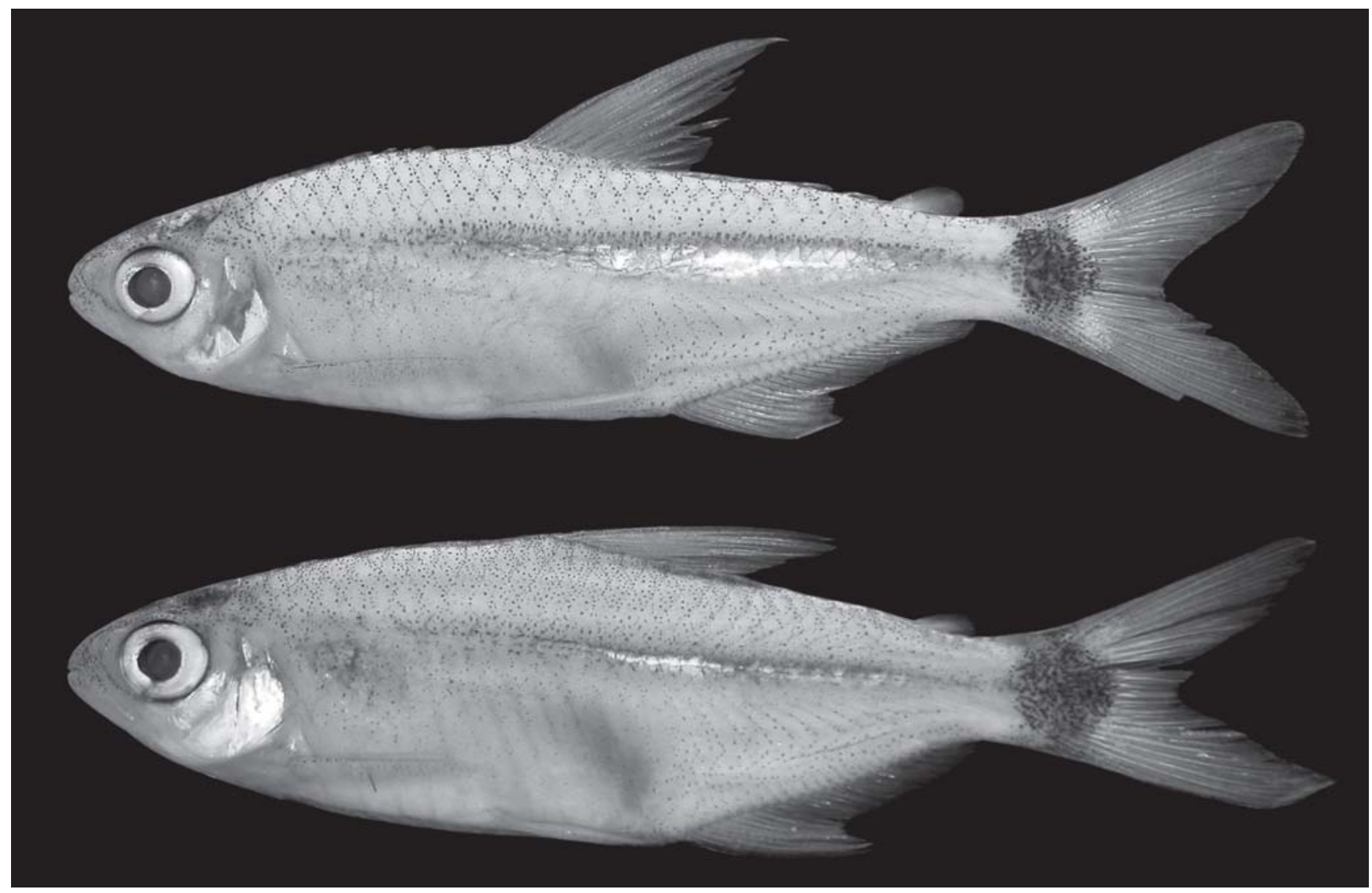

Fig. 1. Neotype of Odontostilbe fugitiva, MUSM 27501, male $34.6 \mathrm{~mm}$ SL (top), and specimen NRM15719, female 35.2 mm SL (bottom). 
synonyms of $O$. fugitiva, table with measurements and meristics of type material of $O$. madeirae Fowler and $O$. drepanon Fowler]. -Géry, 1977: 555, 558 [in key, $O$. madeirae, $O$. drepanon and $O$. caquetae as synonyms of Odontostilbe fugitiva, compilation of Fowler's drawings of $O$. madeirae and $O$. drepanon]. -Sánchez-Botero \& Araújo-Lima, 2001: 440 [listed] - Petry et al., 2003: 562, 565,575 [habitat, listed].

Chirodon fugitivus. -Lütken, 1875: 237 [listed; Amazon basin, Pebas].

Chirodon (Odontostilbe) fugitiva. -Steindachner, 1882: 39 [redescription based on specimens from Amazon basin, Villa Bella, Santarém].

Cheirodon fugitiva. -Ulrey, 1895: 288-290 [in key; erroneous compilation of distribution in Petras (= Pebas), and Brazil]. -Ortega \& Vari, 1986: 8 [listed, Amazon basin, distribution compiled from Géry (1964)].

Odontostilbe madeirae Fowler, 1913: 527-529 [description, type locality: tributary of rio Madeira, near Porto Velho, Brazil; fig. 6, illustrated specimen; holotype ANSP 39193, 16 paratypes ANSP 39194-209: 12 ANSP 39194, 1 ANSP 39206, 1 c\&s ANSP 39207, 1 ANSP 39208, now Géry collection, 1 missing ANSP 39209, same data as holotype]. Fowler, 1948: [in list; 197-198, rio Madeira; compilation of drawing of original description]. -Böhlke, 1954: 138 [in list].

Odontostilbe drepanon Fowler, 1913: 529-532 [description, type locality: tributary of rio Madeira, near Porto Velho, Brazil; fig. 7, illustrated specimen; holotype ANSP 39210, 6 paratypes ANSP 39211-16, same data as holotype]. Fowler, 1948:195-196 [in list; rio Madeira; compilation of drawing of original description]. -Böhlke, 1954: 138 [in list].

Odontostilbe caquetae Fowler, 1943: 230-232 [description, type locality: Florencia, río Orteguasa, Colombia; fig. 13, illustrated specimen; holotype ANSP 70495]. -Fowler, 1948: 194195 [in list; Alto Amazonas, Colombia; compilation of drawing and original description]. -Böhlke, 1954: 138 [in list].

? Odontostilbe fugitiva. -Géry, 1964:18-19 [incorrect date of Cope's description 1871, description of one specimen near Iquitos].

Neotype [by present designation]. MUSM 27501, 1 (male $34.6 \mathrm{~mm}$ SL), Peru, Loreto, Amazon basin, [lower] río Napo drainage, Yuto cocha on right bank of río Mazán, 330'53"S 73¹0'05”W, S. O. Kullander, J. Cruz, N. Sarmiento \& A. Hogeborn, 16 Aug 1984.

Type material examined. Odontostilbe madeirae. Holotype ANSP 39193, 1m, x (female $32.1 \mathrm{~mm}$ SL), Brazil, tributary of rio Madeira, near Porto Velho, E. A. Smith, Jan 1913. Paratypes: ANSP 39194, $8 \mathrm{x}, \mathrm{c}$ of 12 females (females 25.3-29.2 mm SL,), same data as ANSP 39193; ANSP 39206, 1 (female $33.0 \mathrm{~mm} \mathrm{SL}$ ), same data as ANSP 39193; ANSP 39207, 1 (female c\&s), same data as ANSP 39193. Odontostilbe drepanon. Holotype ANSP 39210, 1m, x (male 30.5 $\mathrm{mm} \mathrm{SL}$ ), Brazil, tributary of rio Madeira, near Porto Velho, E. A. Smith, Jan 1913. Paratypes: ANSP 39211, 6m, x (males 25.2-28.8 $\mathrm{mm} \mathrm{SL}$ ), same data as ANSP 39210. Odontostilbe caquetae. Holotype ANSP 70495, 1m, x (unsexed 28.0 mm SL). Colombia, Caquetá, Florencia, río Orteguasa Basin, Amazon watershed [rio CaquetáJapurá ], N. Maria, 1932.
Non-type material. Río Ucayali basin, PERU, UCAYALI: CAS 70915, 8 (unsexed 23.8-27.5 mm SL), lago Cashiboya, cut off lake of río Ucayali above Contamana, connected to river by narrow channel. MZUSP 26039, 1 (unsexed $23.8 \mathrm{~mm}$ SL), Coronel Portillo, Iamiricocha, Masisea, [near mouth of río Pachitea]. MZUSP 26066, 1 (male $33.1 \mathrm{~mm} \mathrm{SL}, 3$ unsexed 31.2-34.9 mm SL), río Huacamayo, road Pucallpa-Huánuco. MZUSP 26145, 1 (female 34.7 mm SL), Coronel Portillo, Bagazán [Nuevo Bagazán, río Ucayali]. MZUSP 26151, 16m (11 males, 32.7-37.8 mm SL, 5 females, 34.0-35.9 mm SL), same data as MZUSP 26151. MZUSP 26389, 4 (unsexed 28.8-33.0 mm SL), Pucallpa, Ucayali, río Ucayali. MZUSP 26473, 6m (females 32.1-40.5 mm SL), río Neshuya, road PucallpaHuánucu. USNM 280627, 2 (unsexed 25.9-26.3 mm SL), Coronel Portillo, main channel and side pools of río Ucayali, approximately $10 \mathrm{~km}$ upstream of Pucallpa, $08^{\circ} 31^{\prime} \mathrm{S}$ 74 ${ }^{\circ} 22^{\prime} \mathrm{W}$. USNM 324110, 2 (unsexed 20.4-21.3 mm SL), same locality as USNM 280627. PERU, LORETO: NRM 15720, 2m (unsexed 30.3-30.5 mm SL), quebrada Copal at km 15 on road Jenaro Herrera-Colonia Angamos, 04 ${ }^{\circ} 57^{\prime} \mathrm{S} 73^{\circ} 32^{\prime} \mathrm{W}$. MCP 27380, 5m of 18 (unsexed, 28.3-37.1 mm SL), Maynas, Reserva Nacional Pacaya-Samiria, caño Yarina, Pacaya tributary, 5²0’34"'S 74³0'01'”W. MCP 35585, 1 (unsexed 27.1 $\mathrm{mm} \mathrm{SL}$ ), río Pacaya, cocha Yanayacu, río Ucayali drainage. MCP 35586, 5 (unsexed 24.5-27.4 mm SL), same locality as MCP 35585. MCP 27378, 4 (unsexed 26.5-29.9 mm SL), Maynas, río Pacaya, on the road of lagoons Shauinto and Yanayacu, Reserva Nacional Pacaya-Samiria, 5'16'59''S 74²5'29' 'W. MCP 35587, 1 (unsexed $28.8 \mathrm{~mm}$ SL), río Pacaya, PV2, caño, lago Yarina, río Ucayali drainage. PERU, JUNÍN: AMNH 20910, 1 (female 40.8 mm SL), Osherato, either río Tambo, brook Osherato or brook Onkoneni, [río Tambo basin or río Ene-Tambo, upper río Ucayali]. PERU, PASCO: MCP 14974, 10 (4 males 25.3-27.4 mm SL, 3 females 35.8-38.7 mm SL, 3 unsexed 26.4-29.5 mm SL), Puerto Bermudez, upper río Pachitea. Upper río Ucayali, río Urubamba basin, PERU, CUSCO, LA CONVENCIÓN, ECHARATE: USNM $362022,8 \mathrm{~m}$ of 34 (15 males 30.2-38.6 mm SL [ $4 \mathrm{~m}$ males 32.0-38.6 $\mathrm{mm} \mathrm{SL}$ ], 6 females 33.9-37.2 [4m females 33.9-36.8 mm SL], 13 unsexed 26.1-36.6 mm SL), río Urubamba, quebrada Pakiria. USNM 362027, 3 (females 35.9-38.3 mm SL), Segakiato, quebrada Prokigiato. USNM 362028, 6 (2 males 36.9-38.0 mm SL, 4 unsexed 28.8-35.9 mm SL), Segakiato, río Camisea. USNM 362029, 2 (females 35.3-35.8 mm SL), Malvinas, Cocha Nueva. USNM 362034 , 4 (1 male 38.9 mm SL, 2 females 38.7-39.5 mm SL, 1 unsexed 28.9 mm SL), Peruanita, cocha, Konkariari. USNM 362035, 1 (unsexed 33.8 mm SL), Segakiato, quebrada Anuintoniato. PERU, UCAYALI, ATALAYA: USNM 362024, 6 (4 males 35.1-40.2 mm SL, 2 unsexed 32.3-38.7mm SL), Sepahua, quebrada Shamboyacu. USNM 362031 , 8 (unsexed 26.1-34.2 mm SL), lower río Urubamba, Nueva Itália. USNM 362041, 9 (unsexed 27.9-37.8 mm SL), Sepahua, quebrada Pulija, lower río Urubamba. USNM 362043, 10 (2 males 29.7 mm SL \& $33.7 \mathrm{~mm}$ SL, 7 females 31.9-38.5 mm SL), Sepahua, río Urubamba, quebrada Shambuyacu. Rio Marañon basin, ECUADOR, PASTAZA: FMNH 113504, 2 (unsexed 35.9-36.2 mm SL), stream about $100 \mathrm{~m}$ from beach called Waama, río Pastaza drainage, $02^{\circ} 16^{\prime} 56^{\prime \prime S} 77^{\circ} 11^{\prime} 05^{\prime \prime} \mathrm{W}$. MZUSP 87746, $11 \mathrm{~m}$ (1 male $37.2 \mathrm{~mm}$ SL, 8 unsexed 33.4-43.1 mm SL, 2 females 36.2 -39.3 mm SL c\&s), dead arm of río Pastaza, $02^{\circ} 17^{\prime} 75^{\prime \prime S} 77^{\circ} 10^{\prime} 13^{\prime \prime W}$. ECUADOR, MORONA-SANTIAGO: FMNH 113515, 12m of 26 (6 males 36.4-45.1 mm, 6 unsexed 34.2-42.7 mm SL), tributary of río Pastaza at [Puerto] Pakintsa, $02^{\circ} 15^{\prime} 46^{\prime \prime S} 77^{\circ} 14^{\prime} 17^{\prime \prime}$ W. PERU, LORETO: ASNP 150016, 14m of 24 (7 males 28.1-35.3 mm SL, 7 females 28.8-33.1 mm SL), río Huallaga, Yurimaguas creek. FMNH 113503 , 11 (unsexed 24.0-34.2 mm SL), río Huitoyacu [río Pastaza drain- 
age], about $0.5 \mathrm{~km}$ upstream from the mouth, $04^{\circ} 11^{\prime} 54^{\prime \prime S}$ $76^{\circ} 32^{\prime} 38^{\prime \prime} \mathrm{W}$. INHS 54760, 6 (unsexed 21.2-25.4 mm SL), floodplain along south bank of south channel of río Marañon due south of Nauta, 04³0.6'S 73³4.1'W. MCP 14944, 5 (2 males 29.5-30.7 $\mathrm{mm}$ SL, 3 females $30.6-33.6 \mathrm{~mm} \mathrm{SL}$ ), same data as ANSP 150016. MZUSP 77834, 5m of 49 (28.1-31.3 mm SL), cocha Huanayo, $4^{\circ} 10$ ' 50 "'S 76 33' 5 "W. MZUSP 77843, 5m of 147 (23.0-26.1 mm SL), laguna Huayruri, 337'32 "S 76²4'48"W. NRM 15756, 19 unsexed of 100 (unsexed 14.3-22.7 mm SL), Teniente López, beach and meadows on left bank of río Corrientes, [río Tigre drainage]. NRM 15653, 1 (female $32.5 \mathrm{~mm} \mathrm{SL}$ ), Nuevo Andoas, pools on Isla Yanayacu and right bank sandy beach in río Pastaza. NRM 50321, 13m (3 males 31.4-34.8 mm SL, 4 females 34.2-39.1 mm SL, 6 unsexed 32.3-34.6 mm SL), río Tigre drainage, San Jacinto, quebrada at km 45.5. PERU, MORONA: ANSP 150047, 4 (2 males 34.1$35.6 \mathrm{~mm}$ SL, 2 unsexed 21.9-27.7 mm SL), [río Morona basin], Gosulima Cocha. PERU, HUÁNUCO: ANSP 136951, 4 (females 47.0-48.7 mm SL), Huánuco, vicinity of Tingo Maria, main stream of río Tullamayo, near Puerto Nuevo. Río Yanayacu basin, PERU, LORETO: ASNP 178383, 2m (unsexed 20.4-21.9 mm SL), Maynas, at mouth of caño Chincana \& Emerald Forest Lodge, approximately 25 miles south of Iquitos. Río Itaya basin, PERU, LORETO: ANSP $178908,12 \mathrm{~m}$ (5 males 31.7-35.5 mm SL, 1 female $36.9 \mathrm{~mm}$ SL, 1 female $35.5 \mathrm{~mm}$ SL c\&s, 5 unsexed 29.8-34.7 mm), Maynas, [lower río Itaya] at bridge on Iquitos-Nauta highway, approximately 25 miles SSW of Iquitos. INHS 40226, 1 (unsexed $22.5 \mathrm{~mm} \mathrm{SL}$ ), quebrada Mazana, around $1 \mathrm{~km}$ up from confluence with río Itaya, $\mathrm{S}$ of Belém, Iquitos. Lower río Napo basin, río Mazán, PERU, LORETO: NRM 15719, 6m (3 males 32.2-34.0 mm SL, 3 unsexed 32.8-35.2 mm SL), same data as neotype. Río Ampiyacu basin, PERU, LORETO: ANSP 131535, $1 \mathrm{~m}$ (unsexed $30.8 \mathrm{~mm}$ SL alizarin stained), near Pebas, Chancho caño. CAS 136607, 1m (unsexed $32.8 \mathrm{~mm}$ SL), caño Chancho. CAS 136608, 1m (unsexed $35.2 \mathrm{~mm}$ SL), caño Chancho [lower río Ampiyacu basin, near Pebas]. USNM 175990, 1m (unsexed $35.8 \mathrm{~mm}$ SL), caño [Chancho]. USNM 207666, 1 (unsexed $21.1 \mathrm{~mm} \mathrm{SL}$ ), near [Pevas], río Ampiyacu drainage. Río Orosa basin, PERU, LORETO: INHS 39313, 2 (unsexed 20.0$20.7 \mathrm{~mm}$ SL), Mayuruna Cocha, around 30 minutes by boat downstream of mouth of caño Tonche, 71.7 miles east Iquitos. INHS 39789, 1 (unsexed $23.8 \mathrm{~mm} \mathrm{SL}$ ), lago Pabellon, around 40 minutes upstream by boat from Paucarillo base camp 57.1 miles east Iquitos. Río Yavari / Javari basin, PERU, LORETO: NRM 15671, 3m of (unsexed 26.8-30.6 mm SL), Colonia Angamos, quebrada behind school building. Upper río Amazonas basin, PERU, LORETO: ANSP 136955, 6 (unsexed), vicinity Iquitos, río Nanay opposite naval base, backwater pools off coche, 4 miles above Amazon. ANSP 136958, 3 (unsexed), same data as ANSP 136955. ASNP 178239, 1m (unsexed $35.5 \mathrm{~mm}$ SL), Maynas, río Amazonas main channel along W bank, ca. 30-45 min. upstream from inlet to Iquitos (=mouth río Itaya). CAS 70897, 1 (unsexed $26.6 \mathrm{~mm} \mathrm{SL}$ ), Iquitos, río Amazonas. INHS 39852, 1 (unsexed $21.2 \mathrm{~mm} \mathrm{SL}$ ), río Amazonas, across from Puebla Gallito, 7.68 miles SE Iquitos. INHS 540237, 1 (unsexed $22.9 \mathrm{~mm} \mathrm{SL}$ ), río Amazonas, ca. 10 \& 40 minutes upstream from mouth caño Zapatilla, near town of Yanashi. COLOMBIA, AMAZONAS: FMNH 85346, 27 (unsexed 19.9-25.5 mm), black water river at Yauacaca and first tributary upstream from Leticia on the Colombian side. MCP 14949, $8 \mathrm{~m}$ of 10 ( 1 male 33.4 $\mathrm{mm} \mathrm{SL}, 2$ females 32.7-34.2mm SL, 5 unsexed 31.9-34.0mm SL), Leticia, backwater (the lakes) area cut off from río Amazonas, formerly ANSP 135937. MCP 35263, 2 (males 32.4-34.0 mm SL), same data as MCP 14949, formerly ANSP 135975. ROM 56384, 6 (unsexed 24.2-31.0 mm SL), 10-60 miles upstream from Letícia, río
Amazonas, $4^{\circ} 09^{\prime} \mathrm{S} 69^{\circ} 57^{\prime} \mathrm{W}$. ROM 56443, 42 (9 males 31.8-33.4 $\mathrm{mm}$ SL, 33 unsexed 31.3-33.9 mm SL), same place as ROM 56384. Río Putumayo basin, PERU, LORETO: NRM 26365, 4m (unsexed 21.8-24.4 mm SL), Estrecho, río Putumayo right bank, $02^{\circ} 28^{\prime} \mathrm{S}$ $72^{\circ} 42^{\prime} \mathrm{W}$. COLOMBIA, AMAZONAS: NRM 26430, $3 \mathrm{~m}$ (unsexed 29.5-32.1 mm SL), río Putumayo drainage, Buenaventura, flooded river margin. Rio Jutaí basin, BRAZIL, AMAZONAS: MZUSP 17585, 8 (unsexed 21.4-28.1 mm SL), rio Içapó, mouth of rio Jutaí. Rio Juruá Basin, BRAZIL, ACRE: MPEG 1951, 3 (unsexed 21.0$23.8 \mathrm{~mm}$ SL), Marechal Taumaturgo, rio Juruá, Seringal do Oriente. MPEG 6790, 10m of 30 (unsexed 29.4-32.9 mm SL), Tarauacá, rio Tarauacá. MZUSP 30372, 4m (3 unsexed 20.0-24.7 mm SL, 1 female $32.2 \mathrm{~mm} \mathrm{SL}$ ), same locality as MPEG 6790. MZUSP 31820 , 1 (unsexed $22.8 \mathrm{~mm} \mathrm{SL}$ ), same locality as MPEG 6790. MZUSP 42842, 21 (unsexed 18.5-22.0 mm SL), same locality as MPEG 6790. MZUSP 87749, $2 \mathrm{~m}$ (unsexed 21.6-29.7 mm SL), same locality as MPEG 6790. Rio Japurá Basin, BRAZIL, AMAZONAS: MZUSP 27760, 13 (unsexed 17.9-28.0 mm SL), Tefé, Costa Japão, lower rio Japurá. MZUSP 74964, 22 (unsexed 22.0-31.6 mm SL), Serrinha, rio Japurá in Serrinha, right margin. MZUSP 77466, 2 (unsexed 34.9-36.4 mm SL), Vila Bitencourt. MZUSP 77535, 9 of 19 (unsexed 24.8-28.7 mm SL), rio Japurá in Serrinha. Rio Purus Basin, BRAZIL, ACRE: MCP 37473, 1 (unsexed 38.5 mm SL), small affluent of rio Iaco, road Sena Madureira-Rio Branco, about 8 $\mathrm{km}$ of Sena Madureira. MCP 38106, 2 (unsexed 25.6-24.3 mm SL), rio Acre, Xapuri. MZUSP 49580, 3 (unsexed 20.8-22.4 mm SL), rio Acre. MZUSP 49669, 1 (unsexed $28.2 \mathrm{~mm} \mathrm{SL}$ ), Porto Acre, rio Acre, Seringal Bom Destino (1 hour upper Porto Acre), Instituto. MZUSP 49767, 2 (unsexed 23.0-27.3 mm SL), rio Acre, between Seringal Paraíso and lago Amapá. MZUSP 87754, 29 (unsexed 23.0$33.4 \mathrm{~mm}$ SL), Manoel Urbano, rio Purus. BRAZIL, AMAZONAS: MZUSP 49512, 11 of 22 (unsexed 21.4-27.2 mm SL), Boca do Acre, rio Acre. Rio Solimões basin, BRAZIL, AMAZONAS: MCP 38314, 20 (unsexed 22.5-30.9 mm SL), stream in Jacaré, near Fonte Boa. MZUSP 6315, 1 (unsexed $24.7 \mathrm{~mm} \mathrm{SL}$ ), lago Castro, mouth of rio Purus. MZUSP 9644, 2 (unsexed 23.4-26.6 mm SL), lago Supiá in front of Codajás. MZUSP 9647, 5 (unsexed 16.2-19.5 mm SL), same data as MZUSP 9644. MZUSP 16690, 1 (unsexed $23.8 \mathrm{~mm} \mathrm{SL}$ ), Benjamin Constant, [rio Solimões]. MZUSP 17344, 8 (unsexed 18.8-25.3 mm SL), rio Solimões, Ilha Sorubim, above Coari. MZUSP 17415, 10 (unsexed), same data as MCP 38314. MZUSP 17421, 175 (unsexed 17.9-31.6 mm SL), same data as MCP 38314. MZUSP 17438, 3 (unsexed 18.1-24.9 mm SL), igarapé Manduaçú, paraná de Iupiá, NW Fonte Boa. MZUSP 17498, 5 (unsexed 18.0-37.9 mm SL), rio Solimões, near Ilha de Baruruá, above mouth of rio Jutaí. MZUSP 17395, 33 (unsexed 16.5-28.1 $\mathrm{mm}$ SL), rio Solimões. MZUSP 17520, 2 (unsexed 22.1-30.5 mm SL), Santo Antônio do Içá, mouth of rio Içá. MZUSP 17632, 4 (unsexed 28.7-31.0 mm SL), Fonte Boa, rio Solimões. MZUSP 27751, 13 (unsexed 15.4-24.3 mm SL), Benjamin Constant, paraná do Capacete, rio Solimões. MZUSP 78108, 11 of 23 (unsexed 15.5$21.1 \mathrm{~mm} \mathrm{SL}$ ), Costa do Anori, pool, rio Solimões, near mouth of rio Purus. MZUSP 78109, 3 (unsexed 18.9-21.5 mm SL), same data as MZUSP 78108. USNM 310856, 3 (2 males 34.1-34.4 mm SL, 1 unsexed $33.6 \mathrm{~mm} \mathrm{SL}$ ), muddy igarapé connecting rio Solimões and blackwater lake $c a$. 15 miles west of Coari. BRAZIL, AMAZONAS, municipality of Manaus and proximities (including municipalities of Iranduba or Careiro): INPA 18461, 9 (8 males $32.6 \mathrm{~mm} \mathrm{SL}, 1$ female $35.1 \mathrm{~mm} \mathrm{SL})$, lago Janauacá, mouth of channel. INPA 18465 , $66 \mathrm{~m}$ of 73 (34 males 33.0-36.5 mm SL, 2 males 34.9-37.2 mm SL c\&s, 13 females 32.9-38.1 mm SL, 2 females 34.5-38.4 mm SL c\&s, 15 unsexed 29.7-35.9 mm SL), Ilha da Marchantaria. INPA 18467 , 
25 (7 males 31.7-34.4 mm SL, 18 unsexed 22.5-36.3 mm SL), same locality as INPA 18465 . INPA $18506,10 \mathrm{~m}$ of $50(1$ male $32.4 \mathrm{~mm}$ SL c\&s, 1 female $33.9 \mathrm{~mm}$ SL c\&s, 1 unsexed $23.7 \mathrm{~mm}$ SL c\&s, 7 unsexed 22.2-24.4 mm SL), paraná do Xiborena. INPA 18510, 132 (unsexed 19.1-29.2 mm SL), lago Pirapora, Catalão. INPA 18512, $1 \mathrm{~m}$ (male $34.9 \mathrm{~mm}$ SL c\&s), same locality as INPA 18510. MCP 35775,110 (61 males 30.0-36.2 mm SL, 45 females 30.9-36.9 mm SL, and 4 unsexed 28.8-30.0 mm SL), Janauari, lago Terra Preta. MCP 35777, $12 \mathrm{~m}$ of 36 (6 males 30.6-36.6 mm SL, 6 females 34.5$37.2 \mathrm{~mm} \mathrm{SL}$ ), same locality as MCP 35775. MZUSP 6047, 1 (unsexed $26.9 \mathrm{~mm}$ SL), lago do Rei, Ilha do Careiro. MZUSP 18736, 2 (unsexed 26.3-33.7 mm SL), lago Janauacá, left margin of rio Solimões. MZUSP 18743, 1 (unsexed $33.0 \mathrm{~mm}$ SL), lagoon linked to channel of lago Janauacá, left margin of rio Solimões. USNM 307448, 21 (14 males 32.5-36.7 mm SL, 7 females 37.9 mm SL), São José, lago do Castanho, Janauacá. USNM 308329, 20 (7 males 31.2-34.4 mm SL, 13 unsexed 27.9-34.3 mm SL), lago Terra Preta, Janauari. USNM 310851, 2 (males 31.0-31.4 mm SL), lower rio Negro: igarapé Xiborena ca. $30 \mathrm{~km}$ east Manaus. USNM 315907, 29 (unsexed 20.7-26.9 mm SL), lago Murumuru, cattle enclosure. USNM 332135, 1 (male 32.6 mm SL), near Manaus, lago Janauari, lago Terra Preta. USNM 323629, 3 (unsexed 27.0-29.9 mm SL), northwest shoreline of Ilha Paciência, rio Solimões, southeast of Manaus. Lower rio Amazonas basin, BRAZIL, AMAZONAS: MZUSP 76436, 2 (unsexed 34.4-35.4 mm SL), Parintins, São José, rio Amazonas, left margin, stream mouth. MZUSP 76437, 1 (unsexed $37.6 \mathrm{~mm} \mathrm{SL}$ ), same as MZUSP 76436. BRAZIL, PARÁ: ANSP 150113, 5 (3 males 35.1-35.3 mm SL, 2 females 35.7-36.9 mm SL), paraná-Mirim, lagoa Grande, east of Óbidos. ANSP 149979, 4 (unsexed 34.6-35.6 mm SL), Centro Comercial, brook into lago Grande [near Santarém]. MCP 14959, 4 (3 males 32.6-36.2 mm SL, 1 female $39.2 \mathrm{~mm} \mathrm{SL}$ ), same as ANSP 150113. MZUSP 9498, 7 (unsexed 18.3-24.2 mm SL), Monte Alegre, rio Amazonas. MZUSP 16565, 2 (unsexed 27.0-27.3 mm SL), Oriximiná, Paissandu, [mouth of rio Trombetas]. Rio Madeira Basin, BRAZIL, RONDÔNIA, CALAMA: MCP 38482, $12 \mathrm{~m}$ (5 males 32.1-33.1 mm SL, 7 unsexed 30.9-35.4 mm SL), paraná do Caraparú, rio Madeira. MPEG 3211 , 1 (female 38.6 mm SL), same locality as MCP 38482. MPEG 3213, 1 (female $36.7 \mathrm{~mm} \mathrm{SL}$ ), paraná do Flechal. MZUSP 30212, 1 (unsexed $21.2 \mathrm{~mm} \mathrm{SL}$ ), beach of rio Madeira. MZUSP 30213, 1 (unsexed $24.9 \mathrm{~mm} \mathrm{SL}$ ), same locality as MCP 38482. MZUSP 30216, 1 (female 42.5 mm SL), same data as MPEG 3213. MZUSP 30218, 37 (23 males 29.4-32.8 mm SL, 14 unsexed 29.7-34.3 m SL), same data as MCP 38482. MZUSP 30219, 1 (unsexed $29.2 \mathrm{~mm}$ SL), rio Madeira, mouth of rio Machado. MZUSP 30220, $1 \mathrm{~m}$ (male $33.0 \mathrm{~mm}$ SL). MZUSP 30221, 1 (unsexed 31.4mm SL), rio Madeira. MZUSP 31784, 1 unsexed $30.9 \mathrm{~mm}$ SL, same locality as MCP 38482. MZUSP 35600, 11 (unsexed 21.8-34.2 m SL). MZUSP 42838, 11 (unsexed 15.1-27.6 mm SL), poço da Angélica, rio Madeira. BRAZIL, AMAZONAS: MZUSP 6961, 3 (unsexed 19.7-27.7 mm SL), $25 \mathrm{~km}$ below Nova Olinda. MZUSP 18658, 20 (unsexed 19.1-27.2 $\mathrm{mm} \mathrm{SL}$ ), igarapé Xicanga, $5 \mathrm{~km}$ from Humaitá, east part of Transamazônica. MZUSP 35591, 3 (unsexed 27.3-29.1 mm SL), mouth of igarapé Puruzinho, rio Madeira. MZUSP 35618, 20 (unsexed 21.2-27.9 mm SL), ilha do Puruzinho, rio Madeira. MZUSP 55922, 3 (unsexed 19.2-20.1 mm SL), rio Madeira, $17.3 \mathrm{~km}$ below paraná do Maracá, 340’48"S 595’30"W. MZUSP 57082, 1 (unsexed 25.6 $\mathrm{mm} \mathrm{SL}$ ), rio Madeira, $15.9 \mathrm{~km}$ below paraná do Maracá, 343'6"S 59॰5' 56"W. USNM 310855, 19 (unsexed 18.6-25.2 mm SL), same data as MZUSP 18658. BRAZIL, RONDÔNIA: FMNH 57880, 3 (unsexed 27.7-33.4 mm SL), Santo Antonio, rio Madeira. MZUSP 31821, 1 (unsexed 19.0 mm SL), rio Madeira, cachoeira de Teotônio.
MZUSP 35605, 2 (unsexed 26.7-31.4 mm SL), rio Madeira, cachoeira de Santo Antônio. MZUSP 35610, 2 (unsexed 23.4-27.7 mm SL), same data as MZUSP 35605. MZUSP 42840, 22 (unsexed 16.3-26.9 $\mathrm{mm}$ SL), rio Madeira, cachoeira de Teotônio. MZUSP 74227, 30 of 233 (unsexed 22.0-28.3 mm SL), rio Machado near mouth. MZUSP 74321,30 of 455 (unsexed 23.2-27.9 mm SL), same data as MZUSP 74227. MZUSP 76551, 1 (unsexed 26.0 mm SL), Santo Antônio, rio Machado, beach. MZUSP 76829, 1 (unsexed 27.5 mm SL), Santo Antônio, rio Machado, beach. MZUSP 80041, 30 of 91 (unsexed 22.6-28.6 mm) SL, same data as MZUSP 74227.

Diagnosis. The combination of the following characters distinguish Odontostilbe fugitiva from all the other species of the genus: (1) mouth terminal, mouth slit nearly at horizontal through middle of eye ( $v s$. subterminal, mouth slit at horizontal near lower eye edge in $O$. euspilura and $O$. microcephala; or slightly subterminal, mouth slit at horizontal below middle of eye in $O$. dierythrura); (2) in males snout not very protruding, but slighthly pointed or blunt (vs. very protruded in O. euspilura, $O$. microcephala, and $O$. dierythrura); (3) usually 7 large dentary teeth, with seven cusps (vs. 4 large dentary teeth with 3 large and compressed central cusps and 2, 3 lateral small cusps in O. pequira); (4) elongation of $2^{\text {nd }}$ unbranched dorsalfin ray ( $v s$. no elongation in O. euspilura, or very short elongation in O. pulchra); (5) pectoral-fin never extending beyond pelvic-fin origin ( $v s$. extending beyond in males of $O$. pulchra); (6) branched anal-fin rays 19-24 (mostly 21-22) [vs. 16-20 (mostly 17-18 in O. microcephala, and 17-20 (mostly 18-19) in $O$. euspilura]; (7) $1^{\text {st }}$ to $9^{\text {th }}$ (mostly $6^{\text {th }}-7^{\text {th }}$ ) anal-fin branched rays of males with hooks, positioned at distal half-length of fin rays, tiny hooks occasionally present distally up to $19^{\text {th }}$ anal-fin branched ray ( $v s$. well-developed hooks on $1^{\text {st }}$ to $22^{\text {nd }}$ anal-fin branched rays at distal half length of fin rays in O. pulchra); (8) no hooks found on $1^{\text {st }}$ unbranched pelvic-fin rays (vs. 1-2 unpaired hooks per segment on $1^{\text {st }}$ unbranched pelvic-fin ray occasionally present in O. euspilura and O. pulchra); (9) gill rakers on upper branch usually 6-7, lower branch usually 12-13 (vs. usually 10-12 on upper branch and 14-16 on lower branch in O. microcephala; 11-12 on lower branch in O. dierythrura and $O$. pulchra; 5-6 on upper branch and 9-10 on lower branch in O. euspilura; and 7-8 on upper branch and 13-15 on lower branch in $O$. pequira); and (10) 4 separate supraneurals ( $v s$. supraneurals partially fused in $O$. paraguayensis). Upper gill raker counts differ $O$. fugitiva (5-6) from $O$. ecuadoriensis, $O$. nareuda, and $O$. parecis (6-7).

Description. Morphometric data in Table 1. Largest male 45.1 $\mathrm{mm}$ SL, female $48.7 \mathrm{~mm}$ SL. Body elongate and compressed. Males with more compressed bodies than females. Greatest body depth at dorsal-fin origin. Snout slightly pointed or blunt in males. Head profile gently convex from snout to posterior tip of supraoccipital bone. Predorsal profile slightly convex to straight between posterior tip of supraoccipital bone and dorsal-fin origin, then straight from dorsal-fin origin to caudal peduncle. Ventral profile convex from mouth tip to anal-fin origin. Anal-fin base straight. Caudal peduncle slightly longer than deep. 
Head relatively small. Posterior margin of opercle sinusoidal with upper portion concave and lower portion convex. Mouth terminal, mouth slit nearly at horizontal through middle of eye. Obliquously positioned maxilla ending at vertical near or at anterior border of eye and at horizontal on inferior eye border, not crossing these limits. Dentition (based on $10 \mathrm{c} \& \mathrm{~s}$ specimens and 17 alcohol specimens). Premaxillary teeth 5-6, bearing 6-11 cusps (usually 8, 9, and 10); midcentral cusp longer than others; smaller lateral cusps of each tooth overlap cusps of adjacent teeth, except anteriormost teeth (Fig. 2). Premaxillary teeth juxtaposed external to dentary teeth, leaving premaxillary tooth cusps exposed when mouth closed. Maxilla with 2-3 teeth bearing 1-9 cusps (mostly 7-9), decreasing cusp number toward posterior tip of maxilla. Dentary teeth 8-10 bearing 1-9 cusps, gradually decreasing in size posteriorly, first 6-7 teeth largest with 5-9 cusps (mostly 7), 1 medium-sized tooth with 4-7 cusps and last 1-3 teeth very small, conic or with 2-5 cusps. Smaller cusps of dentary teeth overlaping adjacent tooth cusps, usually not in posteriormost teeth. All dentary tooth cusps upwardly pointed or slightly recurved towards interior of mouth.

Dorsal-fin rays ii(259), 8(1), or 9(258). Dorsal-fin origin slightly posterior to midlength of body, and slightly posterior to pelvic-fin origin. First unbranched dorsal-fin ray in females and immature males about half length of second unbranched dorsal-fin ray. Second unbranched dorsal-fin ray slightly elongate in mature males, extending beyond dorsal-fin distal profile. Anal-fin rays iv(14), v(241) or vi(4), 19(14), 20(57), 21(103), 22(57), 23(23), or 24(5). Anal-fin distal border concave, anterior 6-7 branched rays longest. Pectoral-fin rays $\mathbf{i}(259), 9(1)$, 10(11), 11(135), 12(105), or 13(7). Unbranched pectoral-fin ray reaching or not pelvic-fin origin, never extending beyond that point. Pelvic-fin rays i(259), 6(4), 7(244), 7i(7), or 8(4). Unbranched pelvic-fin ray longest in mature males, extending beyond origin of anal fin. Lateral skin border of unbranched pectoral-fin ray and unbranched pelvic-fin ray thickened in mature males, bearing thin laterodorsal projection of hard tissue covered with soft tissue. Principal caudal-fin rays 19(254), rarely $16(1), 17(1), 18(7)$ or 20(2). Procurrent caudal-fin rays: dorsal 10(34), 11(113), 12(96), 13(9), or 14(4); ventral 7(1), 8(14), 9(133), 10(94), or 11(14). Anterior 1 or 2 ventral procurrent caudal-fin rays sometimes laterally expanded, bifurcated, or S-shaped. Caudal-fin ray flaps ventrally on $2^{\text {nd }}-8^{\text {th }}$ (mostly $4^{\text {th }}-$ $\left.7^{\text {th }}\right)$ branched rays of upper lobe, and dorsally on $12^{\text {th }}-16^{\text {th }}$ (mostly $13^{\text {th }}-15^{\text {th }}$ ) branched rays of lower lobe. Adipose-fin at vertical through last anal-fin ray insertion.

Males with acute, elongate, retrorse hooks on posterior margin of pelvic- and anal-fin rays. One or two (rarely 3 ) paired and unpaired hooks per segment of lepidotrichia, on last unbranched anal-fin ray, and $1^{\text {st }}$ to $8^{\text {th }}$ (mostly $6^{\text {th }}-7^{\text {th }}$ ) anal-fin branched rays, positioned at distal half-length and not extending to ray tip; tiny hooks can be present distally up to $19^{\text {th }}$ anal-fin branched rays in very developed males (e.g. INPA 18506, ANSP 178908, ANSP 15006, and neotype). One or two (rarely 3) unpaired and long hooks per segment of lepidotrichia along almost all length of $1^{\text {st }}$ to $7^{\text {th }}$ branched pelvic-fin rays,

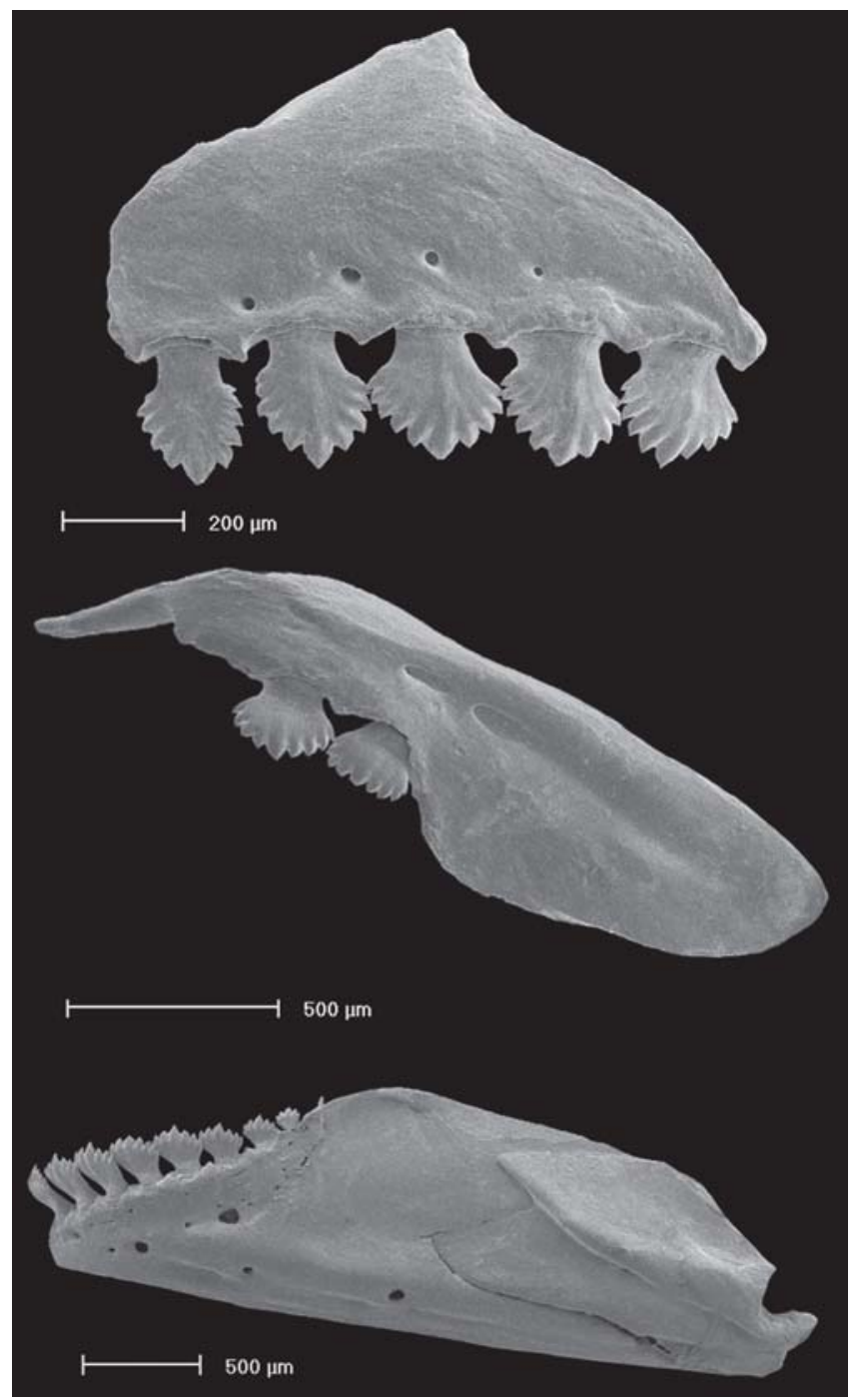

Fig. 2. Dentition of Odontostilbe fugitiva, ANSP 178908, female $35.5 \mathrm{~mm}$ SL. SEM photograph of left side premaxilla (top), maxilla (middle), and dentary (bottom).

reaching distal tip of fin ray (expect on $1^{\text {st }}$ branched pelvic-fin ray, on midlength portion). No hooks found on $1^{\text {st }}$ unbranched pelvic-fin ray. One to 3 unpaired hooks sometimes present on anterior border of anal- and pelvic-fin rays branches.

Scales cycloid; lateral line complete 34(3), 35(21), 36(90), $37(4)$, or 38(1); predorsal row 9(4), 10(98), 11(122), or 12(6); scale rows between lateral line and dorsal-fin origin 5(31), 6(190), or 7(5); scale rows between lateral line and anal-fin origin 4(238) or 5(5); scale rows around caudal peduncle 14(186). Triangular modified scale on pelvic fin base extends posteriorly covering 1-3 scales (mostly 2 ). Scales on anal-fin base 5,6 , or 7 .

Cleared and stained specimens (11): supraneurals 4-5(11); precaudal vertebrae $16(9)$ or $17(2)$; caudal vertebrae $18(3)$, $19(7)$, or 20(1); gill rakers, upper 6(1) or 7(5), lower 12(6) (2-3 on hypobranchial). Alcohol specimens (174): gill rakers, upper 6(83), 7(89), or 8(2), lower 11(15), 12(119), 13(36), or 14(4). Upper gill rakers with 1-5 recurved denticles on anterolateral 

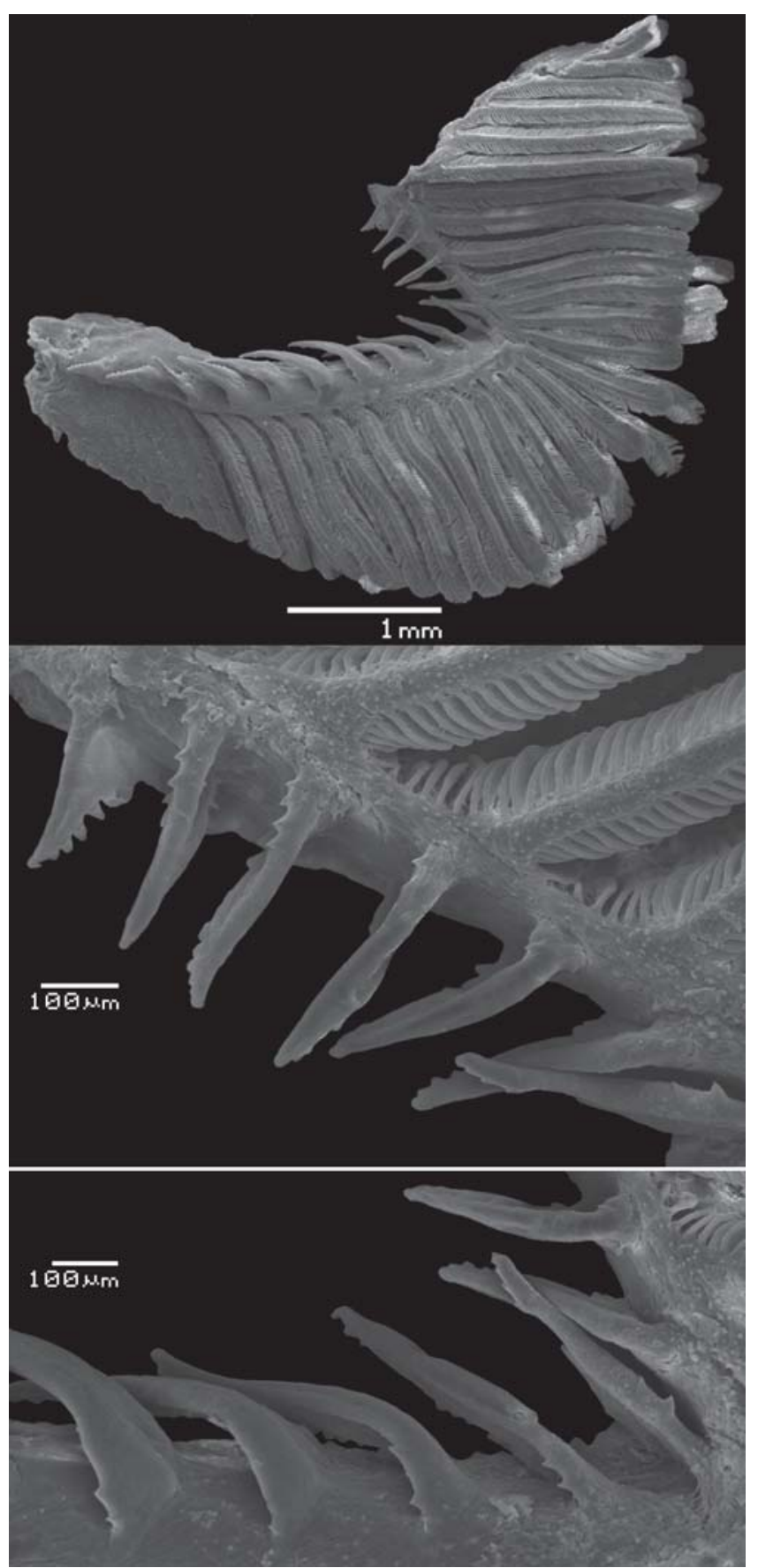

Fig. 3. First gill arch of Odontostilbe fugitiva, MCP 35777 , male $35.7 \mathrm{~mm}$ SL. SEM photographs of the first left side gill arch showing gill gland (top), in detail gill rakers on upper branchial branch (middle), and gill rakers on lower branchial branch (bottom). Lateral view.

border, and anteriormost upper gill rakers with none or 1 similar denticle on posterolateral border; lower gill rakers with 14 denticles on anterolateral border, and none or 1 on posterolateral surface; and posteriormost lower gill raker with none or 1 recurved denticle on anterolateral border, and none, 1 or 2 similar denticles on posterolateral border (Fig. 3). Denticulation mainly on basal portion of gill rakers.
Color in alcohol. General ground body color brownish or pale yellow. Dark dorsum pigmentation from head to caudal peduncle, dark chromatophores mostly on border of scales forming reticulated pattern. Pigmented scales extend laterally on body below longitudinal stripe, also on pseudotympanum area or not. Dorsal fin entirely scattered with dark chromatophores along fin rays, densely along $1^{\text {st }} 2^{\text {nd }}$ unbranched dorsal-fin rays. Dark chromatophores along $1^{\text {st }}-9^{\text {th }}$ dorsal branched fin rays, except almost hyaline $9^{\text {th }}$ branched fin ray. Pectoral and pelvic fins with scattered dark chromatophores, more numerous on anteriormost portions of fins. Fresh specimens only with $7^{\text {th }}$ branched pelvic-fin ray hyaline. Neotype with 1$5^{\text {th }}$ branched pelvic-fin rays pigmented. Pelvic fin mainly hyaline in old-preserved specimens. Anal fin with dark chromatophores spread on all fin rays or on more central branched anal-fin rays, except at tips of last unbranched fin rays and $1^{\text {st }}$ branched fin ray. Adipose fin not pigmented. Caudal fin almost entirely covered with diffuse dark chromatophores along fin rays, except clear areas on base of caudal-fin lobes just behind caudal-fin spot. Rounded black to brown spot on base of caudal fin, reaching upper and lower border of peduncle, or upper border only, sometimes extending little onto proximal portion of $7^{\text {th }}$ to $12^{\text {th }}$ central principal caudal-fin rays.

Numerous dark chromatophores, somewhat contiguous, on snout, upper and lower lips, anteriormost portion of maxilla, and $1^{\text {st }}, 2^{\text {nd }}$, and $6^{\text {th }}$ infraorbitals. Top of head on frontals and parietals pigmented, with deep-lying dark chromatophores over brain membranes below frontals and parietals, and fontanel. Body with faint dark and silver midlateral stripe, sometimes forming black line along middle longitudinal body axis, beginning behind or on pseudotympanum, above lateral line, and reaching caudal spot. Guanine on eye iris, opercle, isthmus, and most of $3^{\text {rd }}$ infraorbital. Below lateral line, belly faint almost without pigmentation, chromatophores above anal-fin base forming 12 to 15 chevron shaped markings.

Color in life. Life color of specimen from lower Ucayali drainage (Fig. 4). One red spot on base of each caudal fin lobe, just posterior to caudal fin black blotch. Red and yellow pigments most on dorsal and anal fins. White pigment on tips of last unbranched and $1^{\text {st }}-2^{\text {nd }}$ branched anal-fin rays, and of unbranched and first branched pelvic-fin rays.

Sexual dimorphism. Males with hooks on anal- and pelvicfin rays, and elongate dorsal- and pelvic-fin rays, in contrast to absence of these features in females. A gill gland (Burns \& Weitzman, 1996) present in mature males on first gill arch, covering about 8 to 10 anterior branchial filaments (Fig. 3). Sexual dimorphism in general body shape is also recognized by principal component analysis performed on measurements of males and females (Fig. 5). Principal component 2 (PC2) grouped males and females separately. It was affected strongly and negatively by pelvic-fin length, snout length, and dorsal-fin length; and positively by depth at dorsal-fin origin. Males are particularly distinct from females in all of these characters, having higher values of pelvic-fin length, snout 


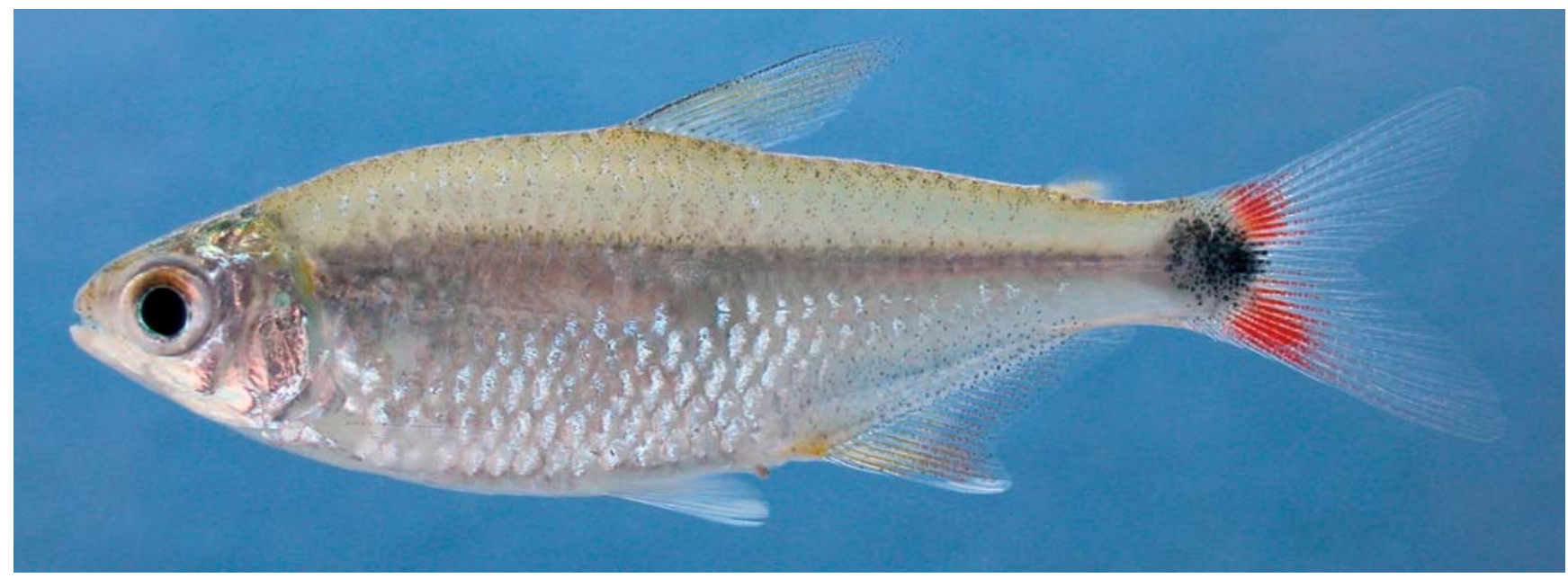

Fig. 4. Odontostilbe fugitiva from lower río Ucayali drainage. Photo by William Crampton (Ucamara Project).

length, and dorsal-fin length than females, while females have higher depth values at dorsal-fin origin than males (Table 1). Principal component 3 (PC3) was affected strongly and positively by snout length and upper jaw length, and negatively by pelvic-fin length and dorsal-fin length. Variation on PC3 seems to be related to the level of development of pelvic- and dorsal-fin rays, snout protusion (snout length, and upper jaw length) in males, because males with higher values for these features are located upper on PC3 axis (Fig. 5).

Remarks on the holotype of Odontostilbe fugitiva. The short description of $O$. fugitiva by Cope (1870) makes no reference to type specimens. Most type-specimens of fishes described by Cope were deposited at ANSP, although some at USNM and some are missing (Böhlke, 1984; Vari \& Howe, 1991). Henry W. Fowler was the first full-time curator of the fish collection at ANSP, and one of his first tasks was the cataloging of the extensive collection of Edward D. Cope (Böhlke, 1984). During his stay at ANSP, Fowler $(1913: 529,532)$ described $O$. madeirae and $O$. drepanon and Fowler (1940) $O$. dierythrura and $O$. hasemani, but he did not mention any type specimens for $O$. fugitiva. Finally, when describing $O$. caquetae, Fowler (1943: 232) stated that the type of $O$. fugitiva was lost. Géry (1972a) also affirmed the holotype of $O$. fugitiva was lost after visiting ASNP to study Fowler's type material. Vari \& Howe (1991) did not list O. fugitiva among characiform type specimens at USNM.

Böhlke (1984: 46) indicated ANSP 8059 as the holotype of $O$. fugitiva, and noticed that "original Cope label and catalog indicate this to be type of O. fugitiva". However, in the same publication, Böhlke (1984: 46) remarked the same lot (ANSP 8059) was listed by Fowler (1906) as the holotype of Aphyocharax filigerus, valid as Prionobrama filigera (Cope, 1870). Examination of ANSP 8059 confirmed this is a specimen of $P$. filigera. Both authors have fruitlessly searched the ANSP and USNM fish collections after the type material of $O$. fugitiva [including the lot ANSP 8073 listed by Fowler (1906) as cotypes of Aphyocharax filigerus].
Neotype designation. Odontostilbe fugitiva is the type species of Odontostilbe, and the designation of a neotype, as well as establishment of the identity of the type species is essential in solving nomenclatural questions among cheirodontines. The neotype was not caught at Pebas, the original type locality of $O$. fugitiva. Pebas is located at the confluence of río Ampyiacu with río Amazonas, Loreto, Peru. The neotype is a mature male from an affluent of lower río Napo basin, río Mazán, upper rio Amazonas, Loreto, Peru. Río Mazán is to the west of the type locality, being the nearest site (Fig. 6) with the best preserved mature male (Fig. 1) available, being in conformity with ICZN (1999). Since secondary sexually dimorphic characters are important to distinguish Odontostilbe and other Cheirodontinae genera, a mature male is preferred as the neotype. The chosen male has entire elongate $2^{\text {nd }}$ unbranched dorsal-fin ray and unbranched

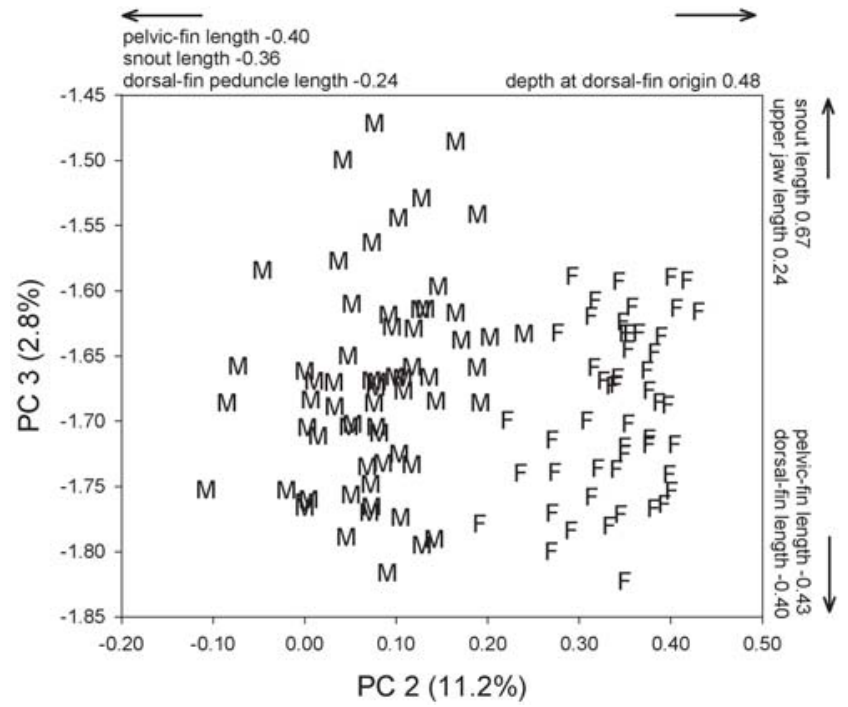

Fig. 5. Principal component analysis of the 18 morphometric data of males (M) and females (F) of Odontostilbe fugitiva. Stronger loadings on the second and third principal components (PC2, PC3). 


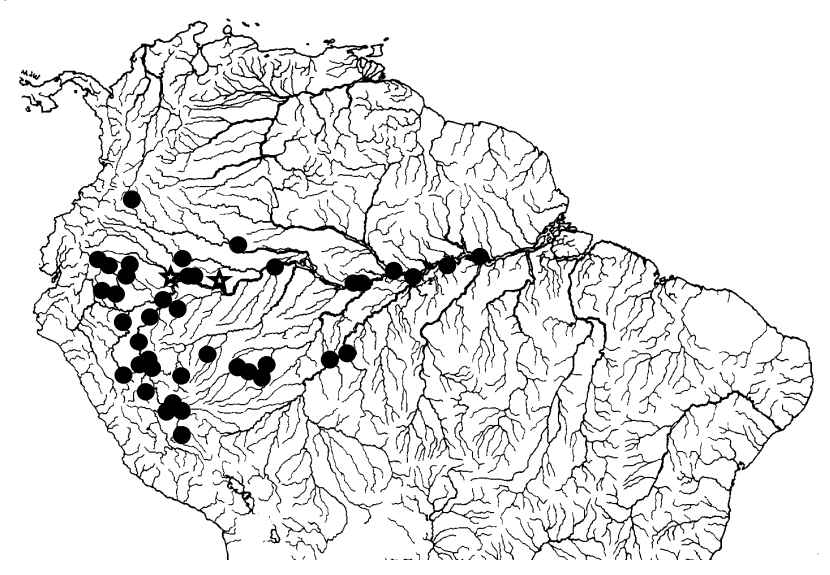

Fig. 6. Distribution of Odontostilbe fugitiva in central and northen South America. Circles (material examined, symbols can represent more than one lot, and more than one locality), and stars (type locality of neotype on the rigth and of the lost holotype on the left).

pelvic-fin rays, well-developed acute retrorse hooks on pelvic- and anal-fin rays, preserved scales, and well-preserved color pattern (Fig. 1). Cope (1870: 566) referred to a "transverse line [of scales] at vent 11; at ventral fins 5-5". Although distinct from the counts of the neotype, these counts are included in the range found herein for the species (5-7 between lateral line and dorsal-fin origin and 4-5 between lateral line and anal-fin origin).

The status of Odontostilbe madeirae and Odontostilbe drepanon. Both species were described in the same paper by Fowler (1913). The holotype (Fig. 7) and all paratypes but one of $O$. drepanon have the dimorphic characters unique to males of Odontostilbe: elongation of $2^{\text {nd }}$ unbranched dorsal-fin ray and $1^{\text {st }}$ unbranched pelvic-fin rays, and presence of hooks on pelvic-fin rays and anal-fin rays. On the other hand, the holotype (Fig. 7) and all paratypes of $O$. madeirae lack these characters, and have higher body depth, the diagnostic features for females (see Table 1 and description under Sexual Dimorphism above). The two species described by Fowler (1913) overall match the $O$. fugitiva diagnosis, and this is a case of misunderstanding dimorphic males and females as two different species. Fowler (1913: 529) remarked that the absence of "the dark-edged silver lateral band" in O. madeirae is a character to distinguish it from $O$. fugitiva. The holotype and paratypes of $O$. madeirae actually have a faded longitudinal line of chromatophores posterior to the pseudotympanum.

The holotype of $O$. madeirae has few dentary teeth remaining, but laterally 4 teeth remain, each with 7 cusps. Premaxillary teeth 5 with 7-8 cusps and maxillary teeth 2 with 7 cusps. The holotype of $O$. drepanon also lacks most dentary teeth, but on the right side four teeth remain each with about 7 cusps. Premaxillary teeth 5 with 7-9 cusps, and maxillary teeth 2 with 7 cusps. The $2^{\text {nd }}$ unbranched dorsal-fin ray is broken.

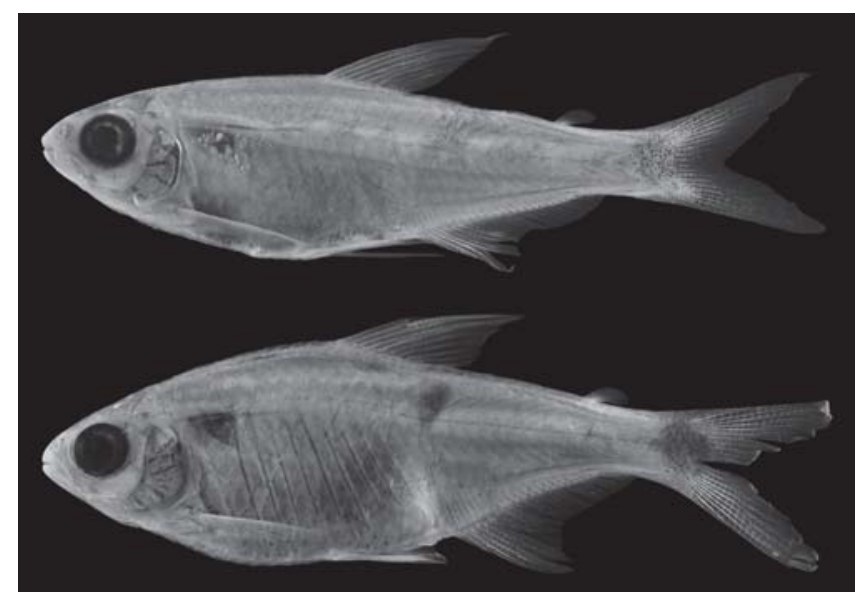

Fig. 7. Holotypes of Odontostilbe madeirae, ANSP 39193 , female $32.1 \mathrm{~mm} \mathrm{SL}$ (top), and Odontostilbe drepanon. ANSP 39210 , male $30.5 \mathrm{~mm}$ SL (bottom - The darkned area below dorsal fin is a preservation artifact).

The status of Odontostilbe caquetae. Odontostilbe caquetae was described from a single immature specimen (28.0 mm SL). Fowler diagnosed $O$. caquetae comparing the holotype with data available in the short redescription of $O$. fugitiva by Eigenmann (1915:93), which was based on four specimens examined from "San Antonio de Rio Madeira", measuring "largest 41 mm". Following Fowler's diagnosis, O. caquetae would have a smaller head, smaller eye and larger snout than $O$. fugitiva. However, measurements and counts of the holotype of $O$. caquetae overlap those of $O$. fugitiva (Table 1), not supporting any of Fowler's diagnostic characters. For that reason, we consider $O$. caquetae as a synonym of $O$. fugitiva.

The holotype is now dark colored and damaged with most dorsal-fin rays and caudal-fin rays broken (Fig. 8). Infraorbitals 2-5 are lacking on the left side. Premaxilla probably would have five teeth, but just two of them remain on each left and right sides, bearing 8-7 cusps. Right maxilla with 2 teeth bearing 8-9 cusps, and left maxilla with only one tooth with 8 cusps. Four dentary teeth remain on each side bearing 5-6 cusps. This dentition is similar to that found in smaller specimens of O. fugitiva, O. pulchra, O. euspilura or O. ecuadorensis. The type locality of $O$. caquetae is Florencia, río Portuguesa, río Caqueta drainage, where O. euspilura occurs (Fowler, 1945b). The main reason for not considering $O$.

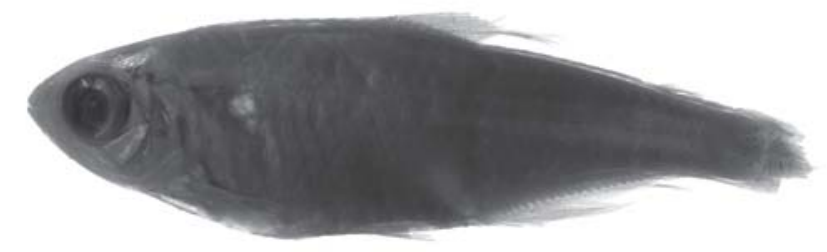

Fig. 8. Holotype of Odontostilbe caquetae, ANSP 70495, unsexed $28.0 \mathrm{~mm}$ SL. 
caquetae as synonym of $O$. euspilura is the terminal mouth in the former, against the inferior mouth in the latter.

The first right gill arch of the holotype was found cut off from branchial apparatus, but kept under the operculum. Both first gill arches have 6 gill rakers on upper branch and 11 on lower branch. Fowler (1943: 232) described 7+11 gill rakers and it is possible the first gill raker was lost in the damaged upper branches of both gill arches. Specimens of Odontostilbe examined from rio Japurá, the Brazilian name for mid and lower río Caqueta, match $O$. fugitiva in measurements and counts, including 6, 7 gill rakers on upper gill arch and 12 on lower (one among 10 examined specimens of rio Japurá has $6+11$ gill rakers as the holotype of $O$. caquetae). Therefore we consider $O$. caquetae as synonym of $O$. fugitiva. However, we consider this synonym provisional since no mature males of Odontostilbe were available from upper río Caqueta or rio Japurá.

Distribution and geographical variation. Odontostilbe fugitiva is the most widespred Odontostilbe species in the Amazon basin, occurring from the major western tributaries to the lower rio Amazonas (Fig. 6). More extense records are from the río Ucayali, río Marañon, rio Amazonas and rio Madeira basins. Records from western major tributaries of the Amazon, Purus and Juruá systems, are relatively scarce. Predominantly, the species occurs in major whitewater rivers of the Amazon basin, being not so far identified from the rio Negro, rio Trombetas, rio Tapajós, rio Xingu, rio TocantinsAraguaia. The well-sampled fish fauna of the rio Negro did not reveal O. fugitiva (Goulding et al., 1988), though they listed 12 specimens of "Cheirodon sp." (not found at INPA collection). Chao (2001) also did not include $O$. fugitiva in a list of fishes of rio Negro basin and lower rio Branco caught by Project Piaba. Personal searches [CMB] at INPA and Project Piaba fish collections failed in finding $O$. fugitiva in rio Negro

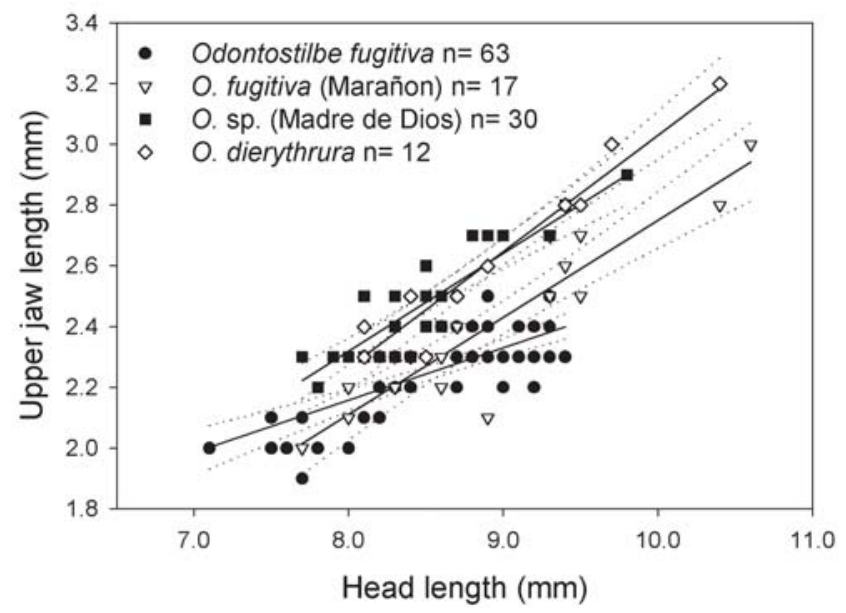

Fig 9. Upper jaw length as a function of head length for males of Odontostilbe fugitiva, specimens widely distributed on rio Amazonas, and upper and middle río Maranõn basin, against $O$. dierythrura and Odontostilbe sp. of río Madre de Dios basin. material. Lowe McConnell (1991) listed O. cf. fugitiva from a tributary of the rio Araguaia, the rio das Mortes. However, the examination of material from the rio Araguaia basin failed to reveal any $O$. fugitiva.

Specimens from upper río Marañon, upper río Ucayali drainages, and middle rio Amazonas (rio Solimões) showed some variation in morphometry. This seems to be related to some exceptionally developed males and females in samples from upper portions of Marañon and Ucayali. Indeed, the largest mature specimens of $O$. fugitiva come from upper río Pastaza, Ecuador (FMNH 113515), and upper río Huallaga, Peru (ANSP 136951), both upper affluents of Maranõn, with some comparable size specimens only from río Urubamba, upper Ucayali. Noteworthy, males from río Marañon basin (río Pastaza, río Tigre, and río Huallaga) show a tendency to have longer snout lengths and upper jaw lengths than males of most populations of upper río Amazonas basin (río Putumayo, río Itaya, río Mazán, río Ampyiacu, río Yavari, and the río Amazonas). However, no additional differences were found to support the recognition of a separate species for río Marañon basin. Some specimens from the upper río Pastaza (FMNH 113515) show a somewhat subterminal mouth similar to $O$. dierythrura and other undescribed species from río Madre de Dios, upper rio Madeira basin. Odontostilbe dierythrura and this undescribed species, however, possess larger upper jaw length (Fig. 9), and more pronounced snouts than $O$. fugitiva, including the Marañon population.

Males of río Ucayali basin also had differences in snout and upper jaw length when contrasted with males from the main rio Amazonas basin, having snout length difference statistically significant in the coincidental regression test $\left(\mathrm{F}_{(2}\right.$, ${ }_{74)}=11.8, \mathrm{p}<0.00$ ) (Fig. 10). When compared to O. fugitiva, $O$. dierythrura and Odontostilbe n. sp. from Madre de Dios, the upper jaw length of the population from río Urubamba, upper Ucayali, remains at an intermediate range between $O$. fugitiva and the other two species (Fig. 11). Again, considering there

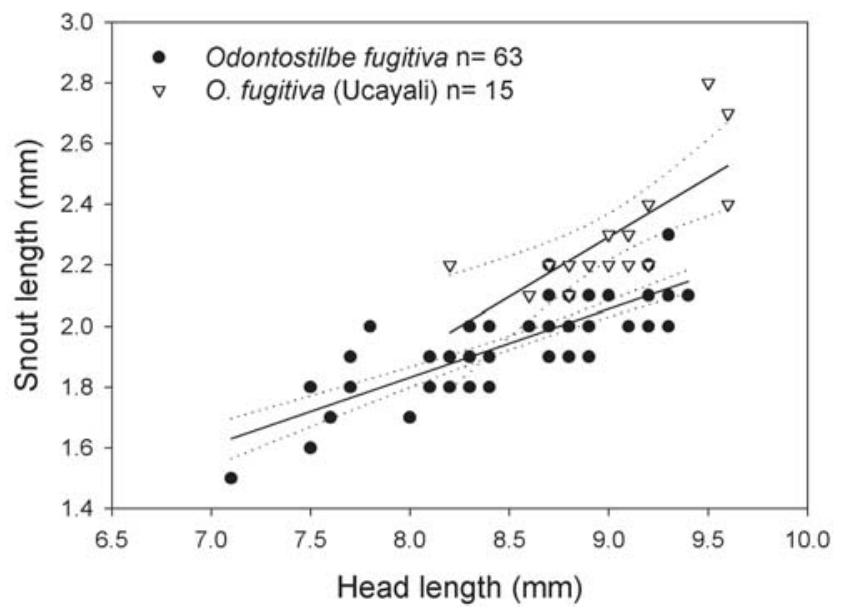

Fig 10. Snout length as a function of head length for males of Odontostilbe fugitiva, specimens widely distributed on rio Amazonas basin against specimens of río Ucayali basin. 


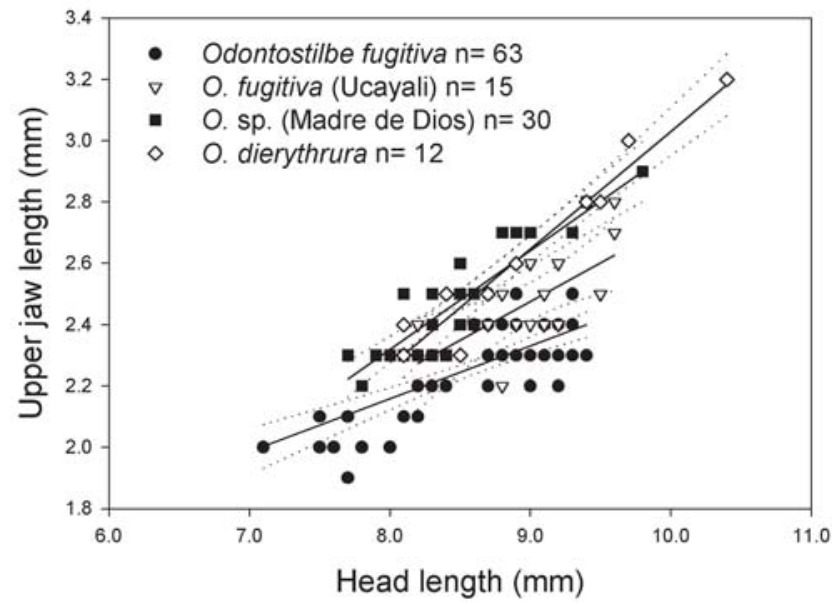

Fig 11. Upper jaw length as a function of head length for males of Odontostilbe fugitiva, specimens widely distributed on río Amazonas basin, and specimens of río Ucayali basin, against $O$. dierythrura and Odontostilbe sp. of río Madre de Dios basin.

were no additional characters differing these populations, and the overlaps in statistics for snout length and upper jaw length, the Ucayali population is considered to be $O$. fugitiva.

A significant statistical difference in measurements was also found when comparing rio Solimões samplings from the region near Manaus to overall $O$. fugitiva material from upper rio Amazonas basin, including río Ucayali and río Marañon systems. Not only males, but females and unsexed specimens jointly, show differences in snout to pectoral-fin length $\left(\mathrm{F}_{(2,200)}=85.6, \mathrm{p}<0.00\right)$ (Fig. 12). This difference is also considered a variation among $O$. fugitiva populations. However, there is a lack of mature males and females among specimens available from an extensive portion of the rio Solimões between

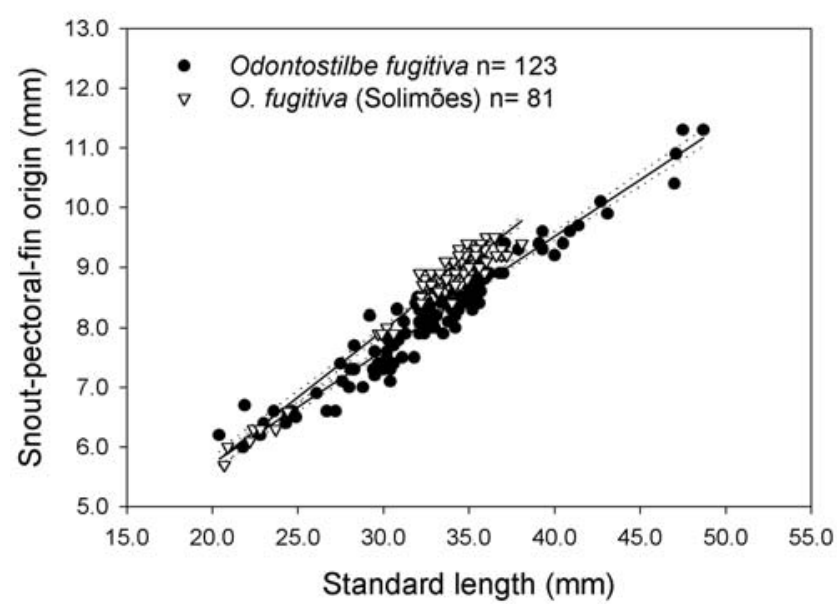

Fig. 12. Snout to pectoral-fin length as a function of standard length for males, females, and unsexed specimens of Odontostilbe fugitiva, specimens widely distributed in rio Amazonas basin against specimens of rio Solimões basin (middle rio Amazonas).
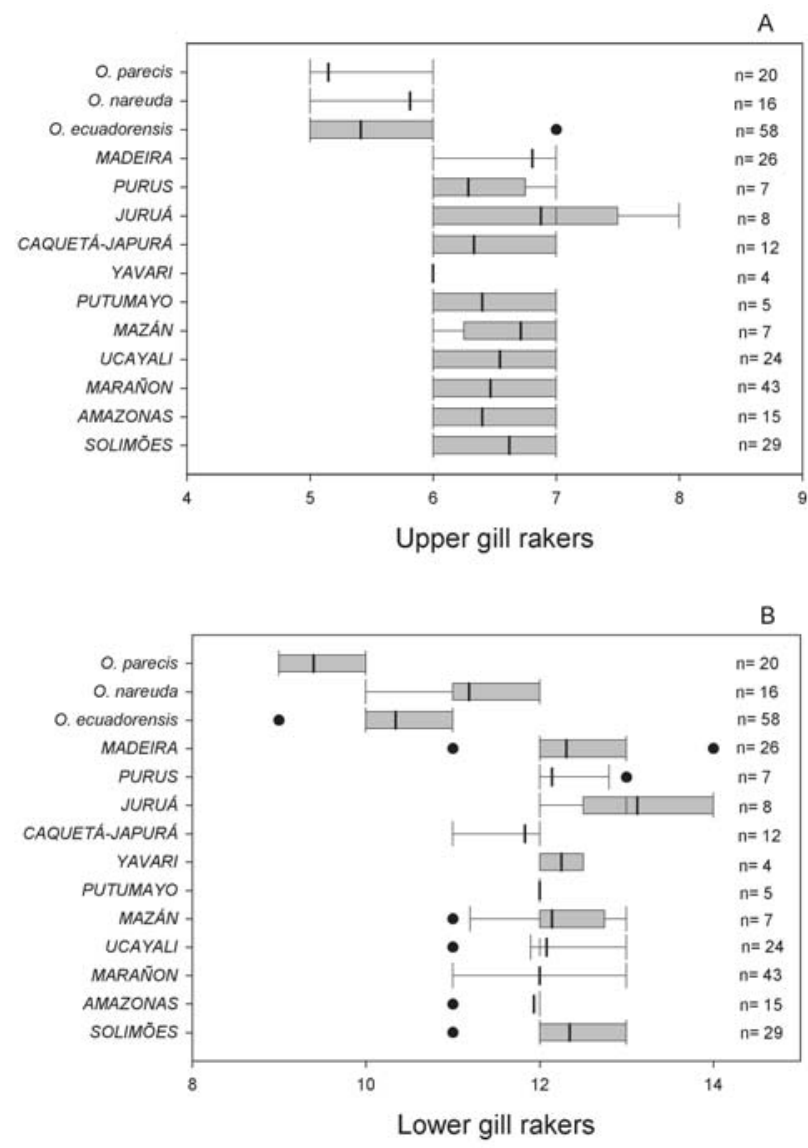

Fig. 13. Upper and lower gill rakers counts of Odontostilbe fugitiva populations, and three new species Odontostilbe ecuadorensis, Odontostilbe nareuda, and Odontostilbe parecis.

Letícia, Colombia, and Manaus, Brazil. Most samples from Solimões consisted of material caught near Manaus by Peter Bayley in 1970s or more recently by INPA researchers.

Examined specimens from rio Juruá basin are unsexed, probably juveniles. Exceptionally, two specimens among 8, have 8 upper gill rakers, and 3 specimens have 14 lower gill rakers (Fig. 13a). Higher gill raker counts occur in $O$. dierythrura and in an undescribed species from Madre de Dios. However, the upper jaw lengths of the avaliable specimens of Juruá fit that of $O$. fugitiva. One specimen of $O$. fugitiva from the rio Madeira also has 14 lower gill rakers (Fig. 13b). Similarly, specimens examined from rio Purus contain only unsexed specimens. In the lack of fully developed, mature specimens, we tentatively assign Juruá and Purus specimens to $O$. fugitiva.

Ecological notes. Recorded mainly from whitewaters; blackwater as "black-muddy" is cited only for FMNH 85346, a stream near Leticia, Colombia. Sánchez-Botero \& Araújo-Lima (2001) referred to Odontostilbe piaba, Odontostilbe sp. and Odontostilbe fugitiva in a list of species associated with roots of aquatic macrophytes during high water period at three floodplain lakes of rio Solimões. Sánchez-Botero et al. (2003) 
Table 1. Morphometrics of Odontostilbe fugitiva, upper rio Amazonas basin (río Ucayali, río Marañon, río Putumayo, río Itaya, río Mazán, río Ampyiacu, río Amazonas, río Yavari, rio Juruá, rio Madeira, rio Solimões). Neotype MUSM 27501 of río Mazán, affluent of mouth of río Napo. Separately, the holotype ANSP 70495 of Odontostilbe caquetae syn. from the río Caquetá basin, the holotype ANSP 39193 of O. madeirae syn., and holotype ANSP 39210 of O. drepanon syn., plus six paratypes ANSP 39211 from the rio Madeira basin.

\begin{tabular}{|c|c|c|c|c|c|c|c|c|c|c|c|c|}
\hline & \multicolumn{3}{|c|}{ Males } & \multicolumn{2}{|l|}{ Females } & \multicolumn{2}{|c|}{ Unsexed } & \multirow{2}{*}{$\frac{\text { O. caquetae }}{\text { Holotype }}$} & \multirow{2}{*}{$\frac{\text { O. madeirae }}{\text { Holotype }}$} & \multirow{2}{*}{\multicolumn{3}{|c|}{$\frac{\text { O. drepanon }}{\text { Holotype n Low High Mean }}$}} \\
\hline & Neotype & $\mathrm{n}$ & Low High Mean & n Low High & Mean & $\mathrm{n}$ Low High & Mean & & & & & \\
\hline Standard length & 34.6 & 88 & $28.145 .1 \quad 34.3$ & 6028.848 .7 & 35.5 & 10220.443 .1 & 31.1 & 28.0 & 32.1 & 30.5 & 625.228 .8 & 27.2 \\
\hline \multicolumn{13}{|l|}{ Percents of standard length } \\
\hline head & 24.3 & 88 & $\begin{array}{lll}23.1 & 27.5 & 25.8\end{array}$ & 6022.127 .2 & 25.0 & 10122.730 .1 & 25.6 & 24. & 24.6 & 25.6 & 625.928 .4 & 27.0 \\
\hline snout & 63.6 & 88 & 0.666 .963 .8 & 6062.970 .2 & 66.2 & 10260.968 .1 & 64.8 & & & 63.0 & 662.864 .3 & 63.6 \\
\hline snou & 48.0 & 88 & $\begin{array}{lll}7.1 & 51.4 & 49.0\end{array}$ & 6047.452 .8 & 50.7 & 10248.353 .6 & 50.4 & 49. & 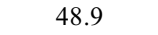 & 46.6 & 647.250 .7 & 49.2 \\
\hline snou & 45.4 & 88 & $\begin{array}{llll}43.7 & 49.6 \quad 46.3\end{array}$ & 6045.351 .3 & 48.0 & 10244.449 .3 & 47.1 & 45 & 47.7 & 44.9 & 644.847 .1 & 46.3 \\
\hline dorsal & 13.6 & 88 & $\begin{array}{lll}13.2 & 15.7 & 14.2\end{array}$ & $6013.1 \quad 15.4$ & 14.5 & 10212.916 .6 & 14.4 & 13 & 4.6 & 13.8 & 613.515 .9 & 14.5 \\
\hline anal- & 27.5 & 88 & 23.528 .926 .7 & 6024.328 .9 & 26.6 & 10124.029 .4 & 26.7 & 24 & 26.2 & 26.9 & 625.327 .6 & 26.4 \\
\hline cauc & 13.6 & 88 & $\begin{array}{lll}11.3 & 15.3 & 13.3\end{array}$ & 6010.913 .9 & 12.4 & $102 \quad 10.814 .4$ & 12.5 & & & 12.5 & 613.114 .0 & 13.6 \\
\hline cauda & 10.4 & 88 & $\begin{array}{lll}9.0 & 12.5 & 11.1\end{array}$ & 6010.113 .0 & 11.5 & $\begin{array}{lll}102 & 9.0 & 12.7\end{array}$ & 10.9 & 10 & & 11.1 & $\begin{array}{lll}6 & 9.9 & 11.8\end{array}$ & 11.1 \\
\hline depth & 28.3 & 88 & $26.6 \quad 35.5 \quad 31.7$ & 6029.641 .3 & 35.9 & 10228.637 .6 & 32.2 & & & 30.8 & 629.033 .1 & 30.1 \\
\hline dors: & 29.8 & 71 & 27.637 .131 .5 & 5027.43 & 30.0 & 912 & 30.0 & & & .8 & 8.537 .2 & 33.5 \\
\hline & & 88 & $\begin{array}{lll}16.9 & 26.8 & 21.2\end{array}$ & 601 & 18.2 & 10215 & 17 & & & 3 & 225.7 & 22.6 \\
\hline & & 88 & $\begin{array}{lll}19.3 & 24.2 & 22.2\end{array}$ & 6018.822 .8 & 21.2 & 10219.3 & 21.1 & & & 21.6 & 622.123 .5 & 22.5 \\
\hline snou & 24.0 & 88 & $23.127 .1 \quad 25.6$ & 6022.126 .8 & 24.8 & 10223.030 .6 & 25.6 & 25.0 & 25.9 & 24.6 & 625.027 .9 & 26.1 \\
\hline \multicolumn{13}{|l|}{ Percents of head length } \\
\hline & & 88 & 1.329 .523 .6 & 6019.124 .7 & 22.0 & 10118.025 .6 & 21.4 & & 22 & 25.6 & 619.424 .7 & \\
\hline upp & .2 & 88 & 23.629 .326 .6 & 6024.030 .0 & 26.7 & 10123.429 .9 & 26.7 & 27.9 & 27.8 & 28.2 & 625.328 .2 & \\
\hline horizo & 36.9 & 88 & $32.3 \quad 38.6 \quad 35.3$ & 6034.041 .3 & 36.9 & 10133.741 .8 & 37.8 & 41.2 & 34.2 & 34.6 & 628.935 .8 & 33.6 \\
\hline least interorbital width & 32.1 & 88 & $29.3 \quad 35.8 \quad 32.7$ & 6030.036 .5 & 32.9 & 10128.837 .0 & 32.7 & 32.4 & 32.9 & 32.1 & 629.832 .0 & 30.8 \\
\hline
\end{tabular}

listed Odontostilbe aff. piaba caught under macrophytes Eichhornia azurea and Eichhornia crassipes in lago Camaleão, considering Odontostilbe among the typical fish genera associated to Eichhornia spp., along with Ctenobrycon, Synbranchus, Hemigrammus, Moenkhausia, Mylossoma, and Hoplias. Some of the fish collected by Sánchez-Botero \& Araújo-Lima (2001) were examined at INPA. Three distinct species of Cheirodontinae were identified by those authors as "O. fugitiva", including two Serrapinnus species, plus $O$. fugitiva. That is not surprising, since $O$. piaba [actually Serrapinnus piaba] for example is used in the literature as a misidentification of several Serrapinnus spp. In any case, Sánchez-Botero \& Araújo-Lima (2001) results pointed out a high abundance of the cheirodontine $O$. fugitiva and at least three Serrapinnus spp. (Serrapinnus micropterus, Serrapinnus gr. microdon, and Serrapinnus n. sp., our identifications) in lakes from the rio Solimões floodplain. Peter Bayley fish collections undertaken during the late 1970's from the same lakes were also extensively examined (material at ANSP, MCP, and USNM), confirming that O. fugitiva is very common in these floodplain lakes. At the same localities, Marchantaria Isle (lago Camaleão), Janauacá, and Janauari, $O$. fugitiva was caught associated with macrophytes Echinochloa polystachya, E. crassipes, Paspalum repens, Panicum sp., or unvegetated places, and considered as omnivorous (Petry et al., 2003).

Two new cheirodontine species provisionally treated as "Odontostilbe", but not described herein, are sympatric and have been found mixed with O. fugitiva in some jars. One of these new species mostly occurs in the río Ucayali basin and the second in the río Marañon basin.

\section{Odontostilbe ecuadorensis, new species}

Fig. 14

Holotype. ANSP 170608, 1 (male 45.7 mm SL), Ecuador, Napo, Santa Cecilia, río Aguarico, $00^{\circ} 06^{\prime} N 76^{\circ} 51$ W; W. G. Saul \& F. B. Cross, 14 Jun 1968.

Paratypes. ECUADOR, SUCUMBÍOS: ANSP 130574, 12m (1 male $45.6 \mathrm{~mm} \mathrm{SL}$, 9 females $42.7-46.7 \mathrm{~mm} \mathrm{SL}$, 1 female $49.1 \mathrm{~mm} \mathrm{SL}$ c\&s, 1 unsexed $35.1 \mathrm{~mm} \mathrm{SL}$ ), backwater of río Aguarico at Santa Cecilia, $00^{\circ} 06^{\prime} \mathrm{N} 76^{\circ} 51^{\prime}$ 'W, W. G. Saul, 30 Jun 1967. MCP 38419 , $12 \mathrm{~m}$ (5 males 32.7-38.6 mm SL, 1 female $40.1 \mathrm{~mm} \mathrm{SL}, 6$ unsexed 24.1-36.2 mm SL), río Napo, beach on south bank, $2.7 \mathrm{~km}$ upstream from bridge at Coca, $00^{\circ} 29^{\prime} \mathrm{S} 77^{\circ} 24^{\prime} \mathrm{W}$, D. Stewart, M. Ibarra, R. Barriga \& Uquillas, 2 Oct 1981. FMNH 113512, 74 unsexed (4 males 32.4-33.4 mm SL, 70 unsexed 28.6-35.0 mm SL), same data as MCP 38419. KU 13524, $15 \mathrm{~m}$ of 32 (7 males 36.3$45.8 \mathrm{~mm} \mathrm{SL}, 2$ males $43.3 \mathrm{~mm} \mathrm{SL}$ and $43.5 \mathrm{~mm} \mathrm{SL}$ c\&s, 2 females $41.7 \mathrm{~mm} \mathrm{SL}$ and $45.2 \mathrm{~mm} \mathrm{SL}, 1$ female $45.2 \mathrm{~mm} \mathrm{SL} \mathrm{c \& s,} 3$ unsexed 33.6-34.8 mm SL), Aguarico, isolated pool at backwater of río Aguarico at Santa Cecilia, W. G. Saul, 27 Jun 1968. KU 13526, 3m (1 male $44.0 \mathrm{~mm} \mathrm{SL}, 2$ females, 47.7-50.2 mm SL), río Aguarico at Santa Cecilia, W. G. Saul, 13 Mar 1967. MEPN 1517, 2 m (1 female $45.2 \mathrm{~mm} \mathrm{SL}, 1$ female $43.6 \mathrm{~mm} \mathrm{SL} \mathrm{c \& s),} \mathrm{Sucumbíos,} \mathrm{río} \mathrm{Duguno,} 2$ $\mathrm{km}$ on south of indian group Cofán del Duguno, Aguarico [drainage], $00^{\circ} 08^{\prime} 15^{\prime \prime N} 76^{\circ} 45^{\prime} 18^{\prime \prime} \mathrm{W}$, R. Barriga \& S. Criollo, 1 May 1995. ECUADOR, NAPO: FMNH 113511, 1m (7 males, 38.2$45.5 \mathrm{~mm} \mathrm{SL}$ ), río Napo, cocha of mainstream, at and $1.2 \mathrm{~km}$ downstream from mouth of río Suyunoyacu ( $c a .16 \mathrm{~km}$ from Coca),

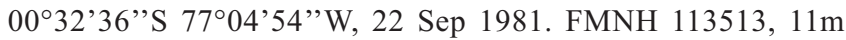
(unsexed 29.6-32.5 mm SL), río San Miguel at Tipishca, km 54.5, [upper río Putumayo], $00^{\circ} 12^{\prime} 30^{\prime \prime} \mathrm{S} 76^{\circ} 13^{\prime} \mathrm{W}$, D. Stewart, M. Ibarra \& R. Barriga., 4 Oct 1983. FMNH 113514, 5m (4 males 40.6-43.2 $\mathrm{mm}, 1$ male $43.5 \mathrm{~mm} \mathrm{SL}$ c\&s, 1 female $40.3 \mathrm{~mm} \mathrm{SL}$ ), Napo, quebrada Capihuara, distributary of río Payamino, [río Coca, río Napo drain- 
age], $00^{\circ} 30^{\prime}$ 'S $76^{\circ} 14^{\prime} 30^{\prime \prime}$ W, D. Stewart, M. Ibarra \& R. Barriga., 13 Nov 1983.

Non-type material. Río Napo basin, ECUADOR, SUCUMBÍOS: ANSP 141496, 2m (unsexed 27.8-28.8 mm SL), [río Pañayacu], $00^{\circ} 25^{\prime} \mathrm{S} 76^{\circ} 07^{\prime} \mathrm{W}$. ANSP $141506,12 \mathrm{~m}$ (unsexed 27.0-31.2 mm SL), Napo, near mouth of río Cuyabeno, $00^{\circ} 16^{\prime} \mathrm{S} 75^{\circ} 53^{\prime} \mathrm{W}$. ECUADOR, NAPO: ANSP 141508, $1 \mathrm{~m}$ (female $36.0 \mathrm{~mm} \mathrm{SL}$ ), mouth of río Shushu Fundi, $00^{\circ} 18^{\prime} \mathrm{S} 76^{\circ} 21^{\prime} \mathrm{W}$. PERU, LORETO, MAYNAS, ARCADIA: USNM 379440, 1 (unsexed $28.5 \mathrm{~mm} \mathrm{SL}$ ), middle río Napo, Padre Isla, cocha Chica. USNM 379469, 1 (unsexed $21.2 \mathrm{~mm} \mathrm{SL}$ ), middle río Napo quebrada Negra 1, en la quebrada Norte. USNM 384420, 1 (unsexed $22.3 \mathrm{~mm} \mathrm{SL}$ ), same data as USNM 379440 . USNM 384822 , 1 (unsexed $18.0 \mathrm{~mm} \mathrm{SL}$ ), río Napo, cocha de Conchas. PERU, LORETO, MAYNAS, CASTANA: USNM 328553, 5 (unsexed 17.0$18.1 \mathrm{~mm} \mathrm{SL}$ ), middle río Aguarico, quebrada Castana Negra. Lower río Napo, PERU, LORETO: ANSP 178148, 2m (unsexed 33.7 -40.9 $\mathrm{mm} \mathrm{SL}$ ), Maynas, beach \& backwater along right bank just upstream from mouth río Mazán, near town of Mazán, 03²9'10'S $73^{\circ} 06^{\prime} 24^{\prime \prime} \mathrm{W}$. INHS 36600, $2 \mathrm{~m}$ (unsexed 30.4-32.0 mm SL), mouth of río Mazán, near town of Mazán. INHS 36658, 1 m (unsexed 37.6 $\mathrm{mm} \mathrm{SL}$ ), $1 \mathrm{~km}$ upstream mouth of río Mazán, $3 \mathrm{~km}$ west town of Mazán. INHS 36668, 1m (unsexed 30.6 mm SL), 1 km upstream mouth of río Mazán, $3 \mathrm{~km}$ west town of Mazán.

Diagnosis. Characters that diagnose Odontostilbe ecuadorensis are: (1) upper gill rakers 5-6, lower 9-11, mostly 10-11 (vs. upper gill rakers 6-8, mostly 6-7, and lower 11-14, usually 12 in O. fugitiva (Fig. 13a-b); (2) denticulation of gill rakers more numerous in $O$. ecuadorensis than in O. fugitiva (in specimens larger than $32.5 \mathrm{~mm} \mathrm{SL}$ ), mainly on posteriormost gill raker of lower arch (5-6 denticles on basal portions of gill raker in O. ecuadorensis vs. 0-2 in O. fugitiva (Figs. 3, 16); (3) elongate $2^{\text {nd }}$ unbranched dorsal-fin ray ( $v s$. not elongate in $O$. euspilura and very short elongate in O. pulchra); (4) no hooks on unbranched pelvic-fin ray (vs. 1-2 unpaired hooks per segment on $1^{\text {st }}$ unbranched pelvic-fin ray occasionally present in O. euspilura and O. pulchra); (5) 1-3 paired or unpaired hooks per segment on last unbranched anal-fin ray, and $1^{\text {st }}$ to $16^{\text {th }}$ anal-fin branched rays (small hooks like knots on anal-fin ray branches, usually on $10^{\text {th }}$ branched fin ray and following rays) ( $v s$. well-developed hooks on $1^{\text {st }}$ to $22^{\text {nd }}$ anal-fin branched rays at distal half length of fin rays in O. pulchra); and (6) usually seven large dentary teeth, with seven cusps (vs. 4 large dentary teeth with 3 large and compressed central cusps and 2, 3 lateral small cusps in O. pequira). Odontostilbe ecuadorensis differs from sympatric $O$. euspilura by its terminal mouth (vs. subterminal mouth).

Description. Morphometric data given in Table 2. Slender and large Odontostilbe species, largest male (holotype) 45.7 $\mathrm{mm}$ SL, largest female $47.7 \mathrm{~mm}$ SL. Body elongate and compressed, more compressed in males than females. Greatest body depth at dorsal-fin origin. Snout pointed in males, rounded in females. Head profile slightly convex from snout to dorsal-fin origin; profile descends from that point almost straight to caudal peduncle. Ventral profile convex from lower jaw to caudal peduncle. Anal-fin base straight. Caudal peduncle slightly longer than deep.
Head relatively small. Posterior margin of opercle sinusoidal with upper portion concave and lower portion convex. Mouth terminal. Maxilla short terminates at vertical near or at anterior eye border, horizontal to lower eye border. Dentition (based on $6 \mathrm{c} \& s$ specimens and 28 alcohol specimens). Premaxillary teeth 4,5 , or 6 , bearing 5-9 cusps (usually 7, 8, or 9); midcentral cusp longest, lateral cusps overlap cusps of adjacent teeth (Fig. 15). Premaxillary teeth juxtaposed external to dentary teeth, leaving premaxillary tooth cusps exposed when mouth closed. Maxilla with 2 or 3 teeth bearing 1-9 (usually 7) cusps, decreasing cusp number toward posterior tip of maxilla. Dentary teeth 8-9 gradually decreasing in size posteriorly, anterior 6 teeth large bearing 5-7 cusps (usually 7), and posterior teeth small, conic or with 2-5 cusps. Smaller cusps of dentary teeth overlap cusps of adjacent teeth, usually not in posteriormost teeth.

Dorsal-fin rays ii(89), 9(89). Dorsal fin slightly posterior to mid body length, and slightly posterior to pelvic-fin origin. First unbranched dorsal-fin ray in females and immature males about half length of second unbranched dorsal-fin ray. Second unbranched dorsal-fin ray elongate in mature males, extending beyond dorsal-fin distal profile. Anal-fin rays iii(1), iv(8), v(78), vi(2); 18(3), 19(15), 20(34), 21(31), or 22(6). Analfin distal border concave, anterior 6-7 branched rays longest. Pectoral-fin rays i(89), 10(8), 11(55), or 12(26). Unbranched pectoral-fin ray reaching or not pelvic-fin origin, never extending beyond pelvic-fin origin. Pelvic-fin rays i(89), 6(1), 7(87), or 8(1). Unbranched pelvic-fin rays longest in mature males, extending beyond origin of anal fin. Lateral skin border of unbranched pectoral-fin rays and unbranched pelvicfin rays thickened in mature males, bearing thin laterodorsal projection of hard tissue covered with soft tissue. Principal caudal-fin rays 19(89). Procurrent caudal-fin rays: dorsal 8(1), 9(3), 10(5), 11(31), 12(44), or 13(5); ventral 8(5), 9(33), 10(41), 11(9), or 12(1). Sometimes 1-2 anterior ventral procurrent caudal-fin rays laterally expanded, bifurcated, or S-shaped. Caudal-fin ray flaps ventrally on $3^{\text {rd }}-8^{\text {th }}$ rays of upper lobe, dorsally on $12^{\text {th }}-16^{\text {th }}$ rays of lower lobe. Adipose-fin at vertical through to last anal-fin ray insertion.

Males with robust, elongate, retrorse hooks on posterior border of pelvic- and anal-fin rays. One to 3 paired or unpaired hooks per segment on last unbranched anal-fin ray, and $1^{\text {st }}$ to $16^{\text {th }}$ branched anal-fin rays, more developed from $1^{\text {st }}$ to usually $7^{\text {th }}$ rays and very small like knots usually on $10^{\text {th }}$ branched fin ray and following rays. Hooks on middle portion of anterior rays and on distal portion after $3^{\text {rd }}$ branched anal-fin ray. One to 3 unpaired acute, elongate hooks per segment of lepidotrichia along almost entire length of $1^{\text {st }}$ to $7^{\text {th }}$ branched pelvic-fin rays, and reaching tip of fin rays (except on $1^{\text {st }}$ branched pelvic-fin ray, on midlenght portion). No hooks found on $1^{\text {st }}$ unbranched pelvic-fin ray. One or two hooks on anterior border of branches of anal-fin rays. One or two hooks on anterior border of branches of pelvic-fin rays.

Scales cycloid; lateral line complete 35(6), 36(42), 37(11), or 38(2); predorsal row 10(37), 11(48), or 12(2); upper trans- 


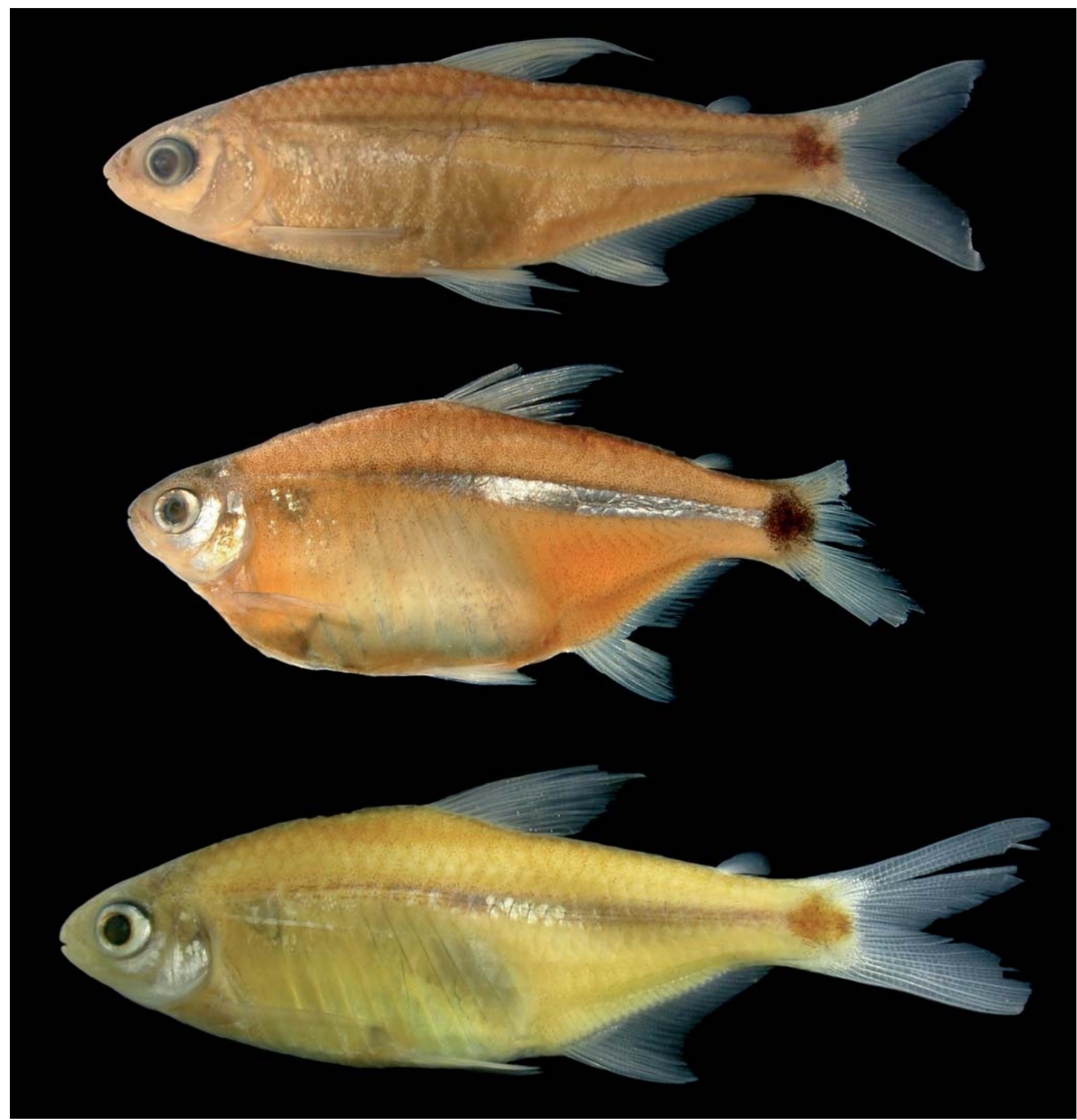

Fig. 14. Holotype of Odontostilbe ecuadorensis, ANSP 170608, male $45.7 \mathrm{~mm}$ SL (top), and paratypes MEPN 1517, 1 female $45.2 \mathrm{~mm} \mathrm{SL}$ (middle) with exceptionally developed ovaries, ANSP 130574, female $46.6 \mathrm{~mm}$ SL (bottom).

verse rows 5(9), $\mathbf{6}(76)$, or 7(2); lower transverse rows 4(87) or 5(1); scale rows around caudal peduncle 14(73). Triangular modified scale on pelvic fin base extends posteriorly covering 2, 3 scales. Scales on anal-fin base 6-8.

Cleared and stained specimens (5): supraneurals 4; precaudal vertebrae, 16(4) or 17(1); caudal vertebrae 18(1), 19(2), or 20(2); gill rakers, upper 5(2) or 6(3), lower 10(2) or 11(3) (2 on hypobranchial). Alcohol specimens (58): gill rakers, upper 5(35), 6(22), or 7(1), lower 9(1), 10(36), or 11(21).
Upper gill rakers with 1-6 recurved denticles on anterolateral border, and 1-3 similar denticles on posterolateral border; lower gill rakers with 1-6 recurved denticles on anterolateral border (1-4 anteriormost lower gill rakers with opposing 1-3 denticles); excepting posteriormost lower gill raker with 3-6 recurved denticles irregularly placed on anterior border, and 4-6 similar denticles on posterior border (Fig. 16a-d). Less numerous in small specimens (one specimen $27.1 \mathrm{~mm} \mathrm{SL}$, with none to 3 denticles on lateral border of upper gill rakers, and 


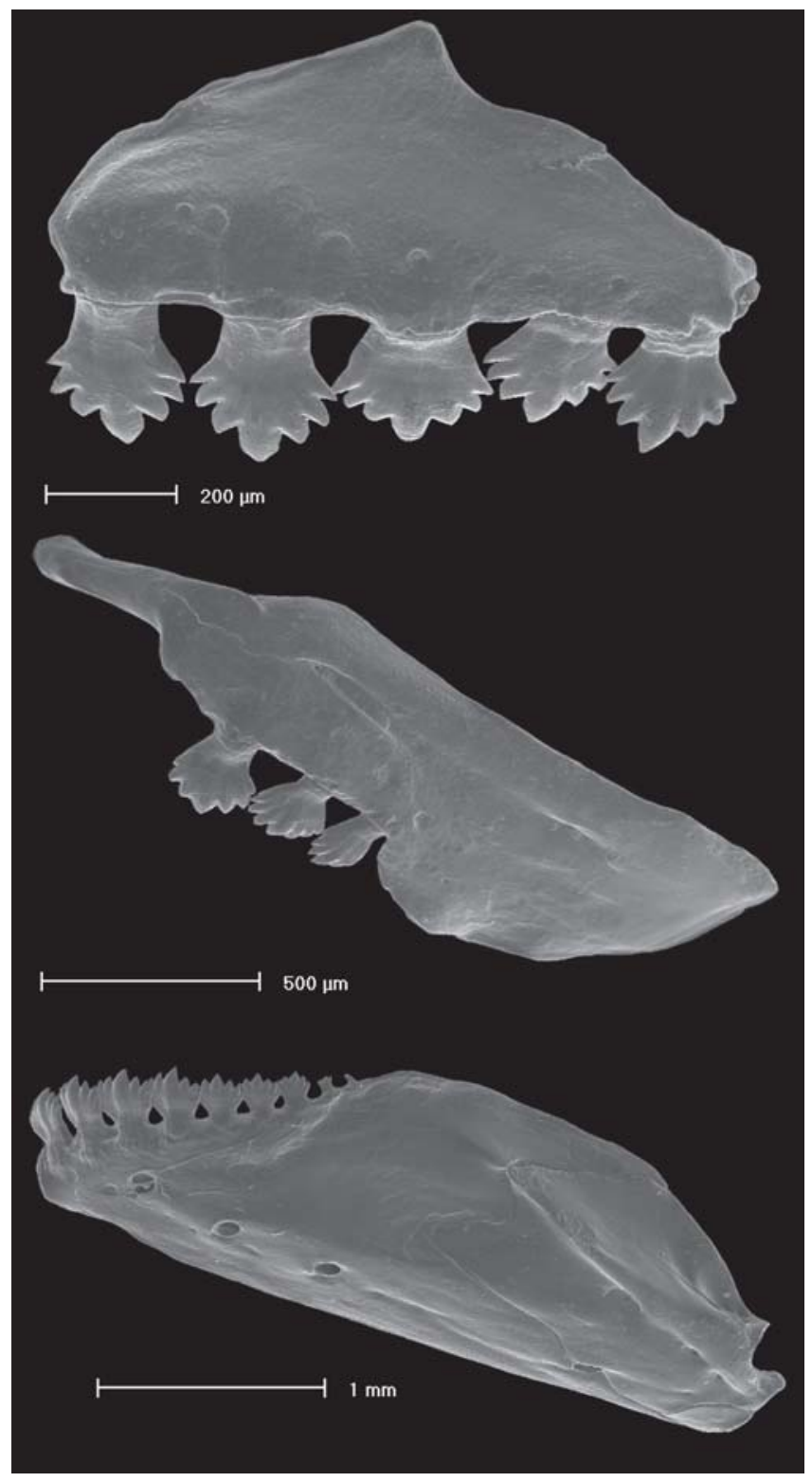

Fig. 15. Dentition of Odontostilbe ecuadorensis, KU 13524, male $43.5 \mathrm{~mm}$ SL. SEM photograph of left side premaxilla (top), maxilla (middle), and dentary (bottom).

none to 3 on lateral border of lower gill rakers). All denticulation mostly on basal portion of gill rakers.

Color in alcohol. General ground body color brownish yellow. Dark dorsum pigmentation from head to caudal peduncle, chromatophores mostly on border of scales. Pigmented scales extend laterally on body above longitudinal stripe, sometimes on pseudotympanum area in well-pigmented specimens. Dark chromatophores on all dorsal-fin rays, along $1^{\text {st }}$ and $2^{\text {nd }}$ unbranched fin rays and faint on $1^{\text {st }}-8^{\text {th }}$ branched dorsal-fin rays, almost hyaline on $9^{\text {th }}$ branched ray. Dark chromatophores on $1^{\text {st }}$ unbranched pectoral-fin ray, less numerous on $1^{\text {st }}$ and $2^{\text {nd }}$ branched fin rays, following branched rays practically hyaline. Pelvic fins usually hyaline, with some dark chromato- phores on unbranched pelvic-fin ray. Anal fin mostly clear with few dark chromatophores. Some specimens bearing dark chromatophores on distal portion of middle branched analfin rays. Adipose fin not pigmented. Caudal fin almost entirely covered with diffuse dark chromatophores along fin rays, except light areas on base of caudal-fin lobes just behind caudal-fin spot. Somewhat rounded brownish caudal spot on base of caudal fin, reaching upper border of peduncle, but never reaching lower border, sometimes extending on proximal portion of $7^{\text {th }}$ to $12^{\text {th }}$ central caudal-fin rays (specimens from río Cuyabeno). Holotype is not well-pigmented, with pelvic and anal fins hyaline.

Black chromatophores on snout, upper lip, sometimes on lower lip, anteriormost portion of maxilla, and $1^{\text {st }}, 2^{\text {nd }}$, and $6^{\text {th }}$ infraorbitals. Pigmentation on top of head on frontals, and parietals with deep-lying dark chromatophores over brain membranes below frontals and parietals, and fontanel. Body with faint dark and silver midlateral stripe, sometimes reduced to one or two parallel lines, along middle longitudinal body axis, beginning above pseudotympanum, above lateral line, and reaching caudal spot. Guanine on eye iris, opercle, isthmus, and most of $3^{\text {rd }}, 4^{\text {th }}$, and $5^{\text {th }}$ infraorbitals. Below lateral line, belly faint, chromatophores just above anal fin-base forming 6 to 10 chevron shaped markings.

Sexual dimorphism. Males with hooks on anal- and pelvicfin rays, elongate dorsal- and pelvic-fin rays, in contrast to absence of these features in females (see description). Gill gland (Burns \& Weitzman, 1996) presents on first gill arch in mature males, covering about 8 to 12 anterior branchial filaments (Fig. 16). Principal component analysis of morphometric data of males and females denotes sexual dimorphism in general body shape (Fig. 17). Principal component 2 (PC2) grouped males and females separately, being affected strongly and negatively by snout length, pelvic-fin length, and caudal peduncle length; and positively by depth at dorsal-fin origin. Males are distinguished from females in all these characters, showing higher values of snout length, pelvic-fin length, and caudal peduncle length than females, while females have higher values of body depth at dorsal-fin origin than males (Table 2). Principal component 3 (PC3) was affected strongly and positively by snout length and upper jaw length, and negatively by pelvic-fin length and dorsal-fin length. Some males have well-developed dorsal and pelvic-fin rays, and protuding snouts (greater snout length, and upper jaw length). This correlates with their heaviest loadings in PC3 forming a group on upper left corner of the graph (Fig. 17).

Distribution. Río Napo, río Putumayo, and río Pastaza basins (a single lot known for the latter) (Fig. 18). Nearly all material from Ecuador, and some lots from Peru on border with Ecuador. The species is also recorded on lower río Napo basin in sympatry with $O$. fugitiva.

Etymology. The epithet ecuadorensis refers to the country where the species was first discovered. 


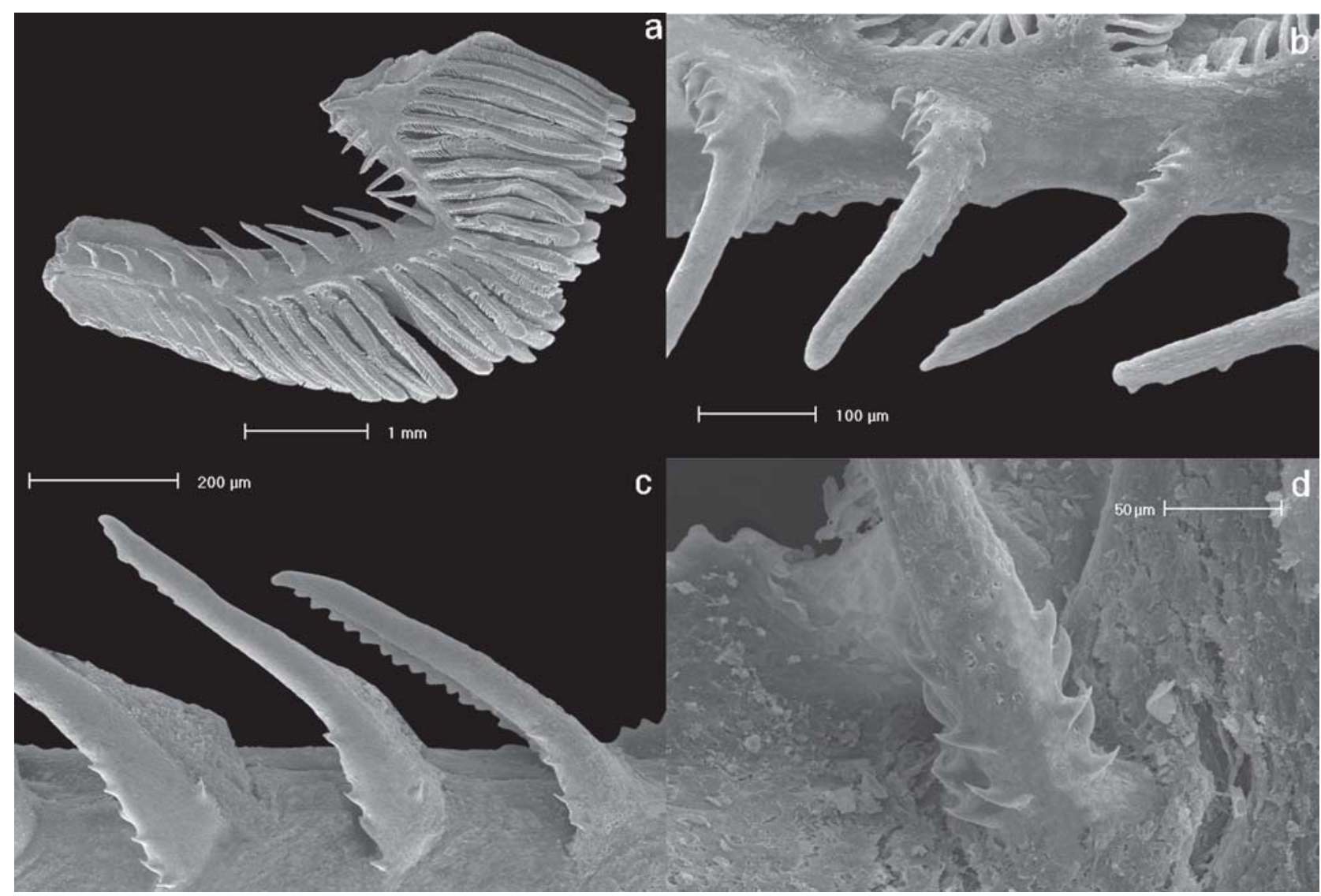

Fig. 16. First gill arch of Odontostilbe ecuadorensis, FMNH 113514, male $40.6 \mathrm{~mm}$ SL (photos a, b, d). SEM photographs of the left side gill arch showing gill gland (a), in detail gill rakers on upper branchial branch (b), gill rakers on lower branchial branch (FMNH 113513, unsexed $32.5 \mathrm{~mm} \mathrm{SL}$ ) (c), and the posteriormost gill raker on the lower branch in detail (d). Lateral view.

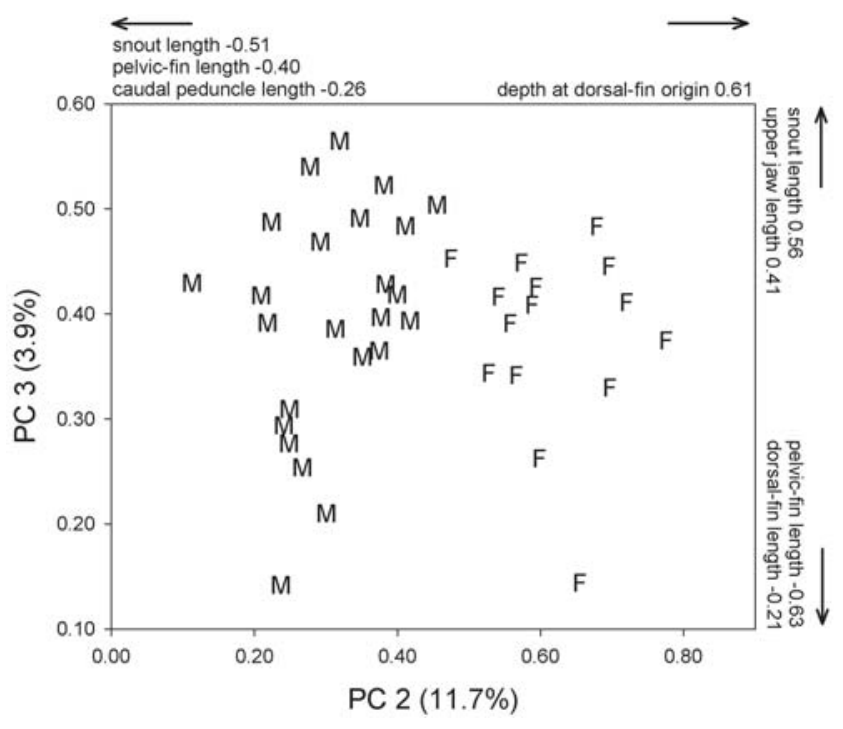

Fig. 17. Principal component analysis of the 18 morphometric data of males (M) and females (F) of Odontostilbe ecuadorensis. Stronger loadings on the second and third principal components (PC2, PC3).
Ecological notes. Saul (1975) identified Odontostilbe cf. madeirae Fowler, 1913, and Holoshesthes heterodon Eigenmann, 1915 as two cheirodontine species commonly taken together in the río Aguarico, the former primarily feeding on algae and plant material, and the latter on insects and insect larvae. However, examination of Saul's (1975) material proved the species named $O$. cf. madeirae to be a mix of $O$. ecuadorensis described herein and $O$. euspilura. The material he named $H$. heterodon consist of an undescribed cheirodontine. Part of the specimens caugth by W. Saul was selected herein as type material for O. ecuadorensis. These Ecuadorian species are reported to occur in clearwater, blackwater or turbid waters, riverine sandy-beaches (Stewart et al., 2002), or lagoons and associated tributaries (Galacatos et al., 1996). All the material examined for this study came from altitudes between 200-500 m. Galacatos et al. (1996) recognized two altitudinal regions in Ecuadorian Amazon, lowland between $200 \mathrm{~m}$ and $220 \mathrm{~m}$, and piedmont between $235 \mathrm{~m}$ and $295 \mathrm{~m}$, where most Odontostilbe species were caught, preferentially in lagoons rather than streams. 
Table 2. Morphometrics of Odontostilbe ecuadorensis n. sp. (holotype ANSP 170608, 12 of ANSP 130574, 2 of MEPN 001517 , 15 of KU 13524, 3 of KU 13526, 7 of FMNH 113511, 11 of FMNH 113513, 5 of FMNH 113514).

\begin{tabular}{|c|c|c|c|c|c|c|c|c|c|c|c|c|c|}
\hline & \multicolumn{5}{|c|}{ Males } & \multicolumn{4}{|c|}{ Females } & \multicolumn{4}{|c|}{ Unsexed } \\
\hline & Holotype & $\mathrm{n}$ & Low & High & Mean & $\mathrm{n}$ & Low & High & Mean & $\mathrm{n}$ & Low & High & Mean \\
\hline Standard length & 45.7 & 27 & 32.7 & 45.8 & 41.4 & 18 & 31.2 & 50.2 & 43.8 & 43 & 24.1 & 46.6 & 32.5 \\
\hline \multicolumn{14}{|l|}{ Percents of standard length } \\
\hline head length & 23.9 & 27 & 23.2 & 26.0 & 24.3 & 18 & 22.2 & 25.3 & 23.2 & 43 & 22.7 & 27.5 & 25.3 \\
\hline snout-anal fin origin & 63.2 & 27 & 62.0 & 67.1 & 64.7 & 18 & 64.5 & 70.8 & 66.8 & 43 & 62.9 & 68.3 & 65.8 \\
\hline snout-dorsal fin origin & 47.3 & 27 & 46.9 & 50.5 & 48.6 & 18 & 48.9 & 52.2 & 50.4 & 43 & 48.6 & 52.4 & 50.5 \\
\hline snout-pelvic fin origin & 45.7 & 27 & 44.2 & 49.0 & 46.5 & 18 & 45.8 & 51.8 & 47.8 & 43 & 46.0 & 49.7 & 47.7 \\
\hline dorsal-fin base & 14.0 & 27 & 13.2 & 14.5 & 13.9 & 18 & 13.2 & 14.9 & 14.1 & 43 & 12.6 & 15.6 & 14.3 \\
\hline anal-fin base & 26.7 & 27 & 23.4 & 27.1 & 25.6 & 18 & 24.8 & 26.7 & 25.6 & 43 & 23.4 & 27.3 & 25.4 \\
\hline caudal peduncle length & 14.2 & 27 & 12.3 & 14.8 & 13.6 & 18 & 11.4 & 13.8 & 12.6 & 43 & 10.9 & 14.0 & 12.8 \\
\hline caudal peduncle depth & 11.8 & 27 & 9.6 & 12.5 & 11.0 & 18 & 10.6 & 12.5 & 11.5 & 43 & 9.7 & 12.1 & 11.0 \\
\hline depth at dorsal-fin origin & 30.6 & 27 & 27.0 & 34.1 & 29.7 & 18 & 32.1 & 43.8 & 36.1 & 43 & 27.0 & 36.7 & 31.8 \\
\hline dorsal-fin length & 32.8 & 23 & 27.7 & 34.9 & 30.3 & 15 & 28.1 & 32.1 & 29.7 & 40 & 27.6 & 31.9 & 29.7 \\
\hline pelvic-fin length & 23.0 & 27 & 17.1 & 24.8 & 19.9 & 18 & 17.0 & 19.0 & 18.1 & 43 & 16.6 & 19.7 & 17.9 \\
\hline pectoral-fin length & 21.7 & 27 & 20.1 & 23.5 & 21.7 & 18 & 20.1 & 23.0 & 21.2 & 43 & 19.1 & 22.5 & 21.1 \\
\hline snout-pectoral-fin origin & 23.2 & 27 & 23.0 & 25.7 & 24.2 & 18 & 22.1 & 25.3 & 23.4 & 43 & 23.3 & 27.7 & 25.2 \\
\hline \multicolumn{14}{|l|}{ Percents of head length } \\
\hline snout length & 25.7 & 27 & 22.8 & 28.6 & 25.0 & 18 & 19.0 & 23.9 & 21.6 & 43 & 19.4 & 24.1 & 22.1 \\
\hline upper jaw length & 24.8 & 27 & 23.1 & 28.3 & 26.4 & 18 & 23.0 & 28.0 & 26.0 & 43 & 23.5 & 29.2 & 27.0 \\
\hline horizontal eye diameter & 32.1 & 27 & 33.3 & 38.1 & 35.6 & 18 & 33.9 & 39.1 & 36.9 & 43 & 35.8 & 40.7 & 37.8 \\
\hline least interorbital width & 33.9 & 27 & 30.6 & 35.6 & 32.9 & 18 & 30.9 & 36.5 & 34.0 & 43 & 29.6 & 36.3 & 32.1 \\
\hline
\end{tabular}

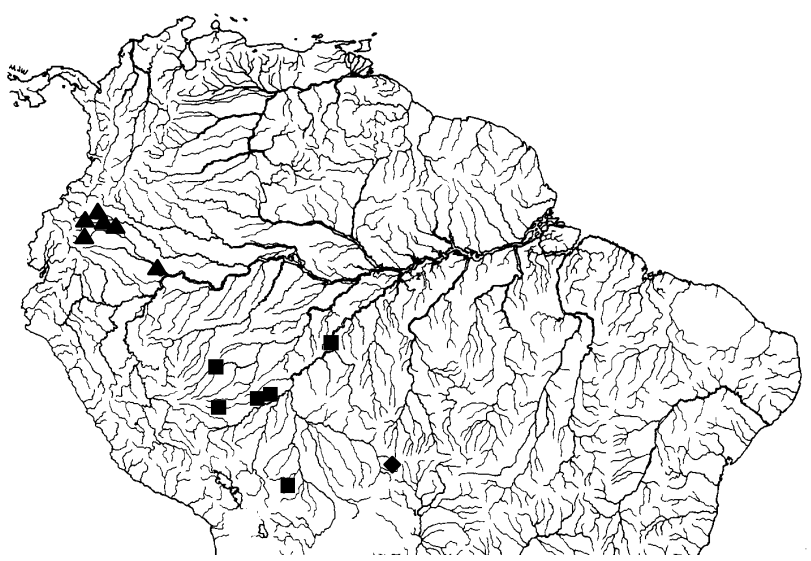

Figs. 18. Distribution of Odontostilbe ecuadorensis (triangles), Odontostilbe nareuda (squares), and Odontostilbe parecis (losangles). Symbols can represent more than one lot, and more than one locality.

\section{Odontostilbe nareuda, new species} Fig. 19

Holotype. CBF 09621, 1 (male $33.1 \mathrm{~mm}$ ), Bolivia, Pando, [río Orthon - rio Madeira basin], lake on right bank of río Nareuda, around 3-4 km above mouth of río Tahuamanu, H. Ortega et al., 10 Sep 1996.

Paratypes. BOLIVIA, PANDO: FMNH 106433, 4m of 17 (2 males 29.4-31.4 mm SL, 1 male $31.6 \mathrm{~mm}$ SL c\&s, 1 female? $32.3 \mathrm{~mm}$ SL, 13 unsexed 19.5-27.1 mm SL not measured), same data as holotype. FMNH 106428, $1 \mathrm{~m}$ (unsexed $30.9 \mathrm{~mm}$ SL), rio Madeira basin, lake on the right bank of río Nareuda, $c a$. 3-4 km above mouth of río Tahuamanu, H. Ortega et al., 10 Sep 1996. FMNH 106430,
$1 \mathrm{~m}$ (unsexed $38.0 \mathrm{~mm} \mathrm{SL}$ ), rio Madeira basin, lake on the right bank of río Nareuda, $c a .5 \mathrm{~km}$ from mouth of río Tahuamanu, J. Sarmiento \& S. Barrera, 11 Sep 1996. BRAZIL, RONDÔNIA: MCP 38417, 20 (1 male $28.8 \mathrm{~mm}$ SL, 19 unsexed 24.0-28.6 mm SL), [Calama], poço da Angélica, rio Madeira, M. Goulding, 12 Dec 1980, formerly MZUSP 42837. MZUSP 87759, $1 \mathrm{~m}$ (female $35.3 \mathrm{~mm} \mathrm{SL}$ ), Calama, M. Goulding, 2 Feb 1981. MZUSP 87760, 5 m (4 unsexed 27.0-34.5 $\mathrm{mm} \mathrm{SL}$, and 1 unsexed c\&s $27.5 \mathrm{~mm} \mathrm{SL}$ ), same data as MCP 38417.

Non-type material. Río Madeira basin, BRAZIL, AMAZONAS: MZUSP 42837, 200 (unsexed 21.5-28.3 mm SL), [Calama], poço da Angélica, rio Madeira. Río Mamoré basin, BOLIVIA, MOTACUSAL: MNHN 1989-1465, 10 of 112 (7 unsexed 21.525.7 mm SL, 3m unsexed- 26.7-28.7 mm SL), río Isiboro, río Mamoré basin. Río Purus basin, BRAZIL, ACRE: MZUSP 87752, 2 (unsexed 26.3-26.8 mm SL), rio Acre, between Seringal Paraíso and lago Amapá. MZUSP 87753, 1 (unsexed 33.1 mm SL), Manoel Urbano, rio Purus. Río Orthon - lower Río Beni basin, BOLIVIA, PANDO: FMNH 106429, 1 (unsexed $20.0 \mathrm{~mm} \mathrm{SL}$ ), lake on the right bank of río Nareuda, around 3-4 km above mouth of río Tahuamanu. FMNH 106432, 3 (unsexed 21.9-30.9 m SL), approx. 2-3 km above mouth of río Muyumanu. FMNH 106434, 2 (unsexed 29.2-29.2 mm SL), right bank of stream Filadelfia, approx. $10 \mathrm{~km}$ from mouth of río Nareuda. FMNH 106435, 2 (unsexed 21.0-21.5 $\mathrm{mm} \mathrm{SL}$ ), hidden lake on right bank of río Tahuamanu, approx. $500 \mathrm{~m}$ from mouth of río Nareuda. FMNH 106436, 1 (unsexed $23.2 \mathrm{~mm}$ $\mathrm{SL}$ ), río Tahuamanu at rocks and island archipelago and rapids, 68 $\mathrm{km}$ below mouth of río Nareuda. FMNH 106462, 1 m (unsexed 28.3 $\mathrm{mm} \mathrm{SL}$ ), río Nareuda at camp, altitude $250 \mathrm{~m}$.

Diagnosis. Odontostilbe nareuda basically differs from all other species by larger anal-fin base length, 30.6-32.8\% SL (e.g. vs. $23.5-29.4 \% \mathrm{SL}$ in O. fugitiva, Fig. 20 , or $23.1-28.5 \% \mathrm{SL}$ in O. dierythrura), and higher anal-fin counts, 24-26 (vs. 16-24 


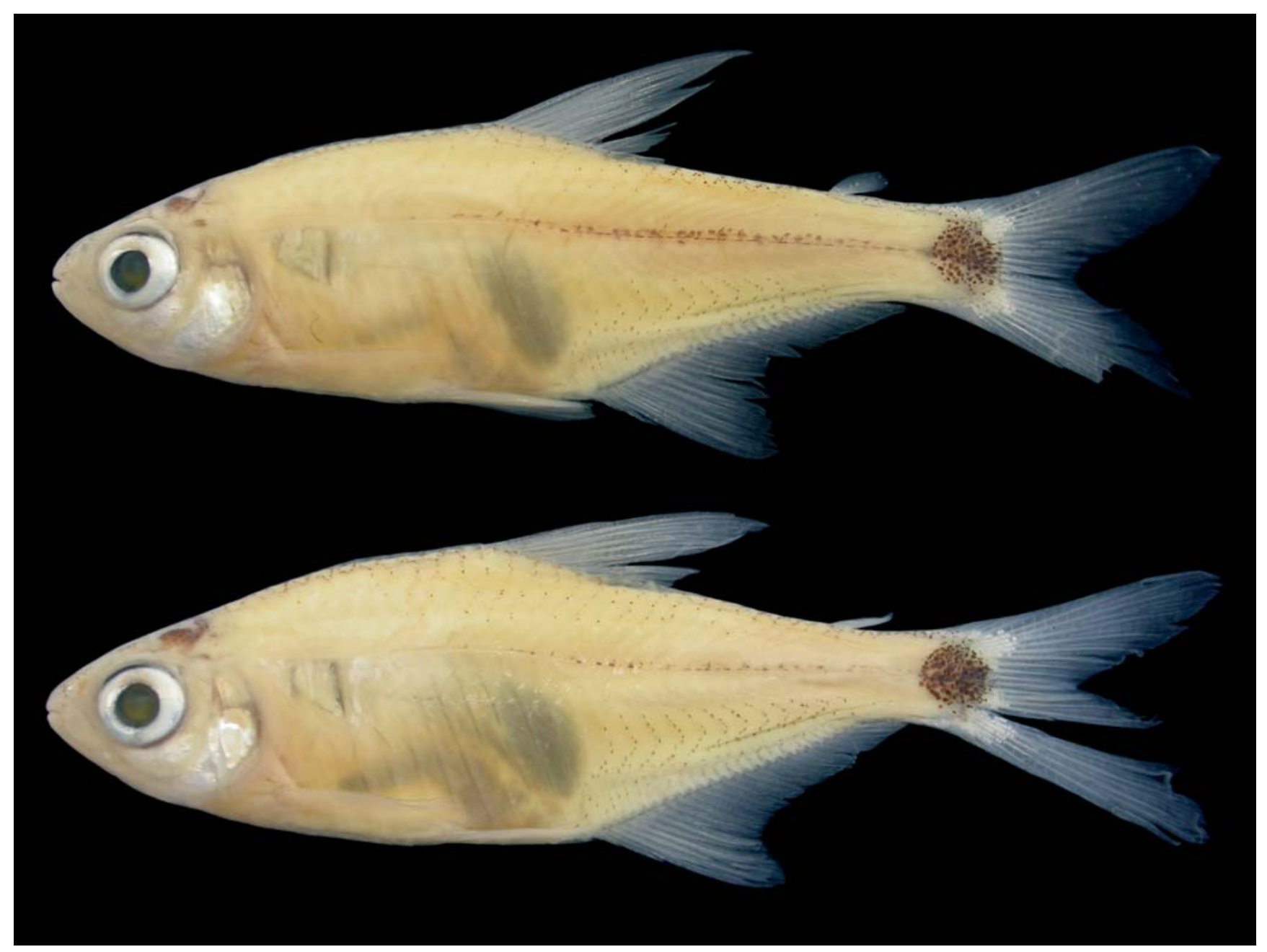

Fig. 19. Holotype of Odontostilbe nareuda, CBF 09621, male $33.1 \mathrm{~mm}$ (top), and paratype FMNH 106433, possibly a female $32.3 \mathrm{~mm}$ SL, not showing dimorphic characters of males (bottom).

for all other species). Adittionaly, gill raker counts on upper branch 5-6 and lower branch 11-12 of $O$. nareuda differ from sympatric species $O$. fugitiva with mostly 6-7 on upper and 12-13 on lower (Figs. 13a-b).

Description. Morphometric data given in Table 3. Largest male $33.1 \mathrm{~mm}$ SL; female $32.3 \mathrm{~mm}$ SL. Body elongate and compressed. Greatest body depth at dorsal-fin origin. Snout usually pointed; not protuded in males. Dorsal profile ascends slightly convex from snout to dorsal-fin origin, and descends straight from that point to caudal peduncle. Ventral profile convex from lower jaw to anal-fin origin, and straight along anal-fin base. Caudal peduncle slightly longer than deep.

Head relatively small. Posterior margin of opercle sinusoidal with upper portion concave and lower portion convex. Mouth terminal. Maxilla short, oblique; posterior tip reaching near or to vertical at anterior eye border, and ending at level of inferior eye border. Cleared and stained specimens (2). Premaxillary teeth 5, bearing 7-9 cusps; midcentral cusp longer than lateral cusps; smaller lateral cusps of each tooth overlap cusps of adjacent teeth, except anteriormost teeth (Fig. 21).
Premaxillary teeth juxtaposed externally to dentary teeth, leaving premaxillary tooth cusps exposed when mouth closed.

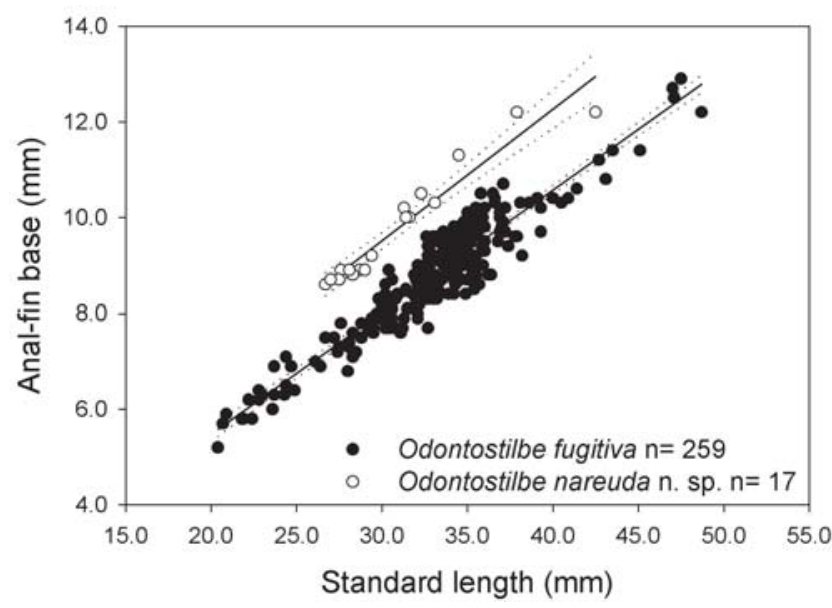

Fig. 20. Anal-fin base as a function of standard length for males, females and unsexed specimens of Odontostilbe fugitiva against Odontostilbe nareuda. 
Maxilla with 2 teeth bearing 2-8 cusps, usually decreasing cusp number to posterior tip of maxilla. Dentary teeth 8-11 bearing 1-7 cusps, gradually decreasing in size posteriorly; anterior 6 teeth large with 5-7 cusps, and remainder small with 1-4 cusps. Smaller cusps of dentary teeth overlaping adjacent tooth cusps, usually not in posteriormost teeth. All dentary tooth cusps slightly recurved towards interior of mouth.

Dorsal-fin rays ii(17) or 9(17). Dorsal-fin origin slightly posterior to midlength of body, and slightly posterior to vertical through pelvic-fin origin. Anal-fin rays v(16), vi(1), 23(3), 24(9), 25(4), or 26(1). Anal-fin distal border concave, about 7

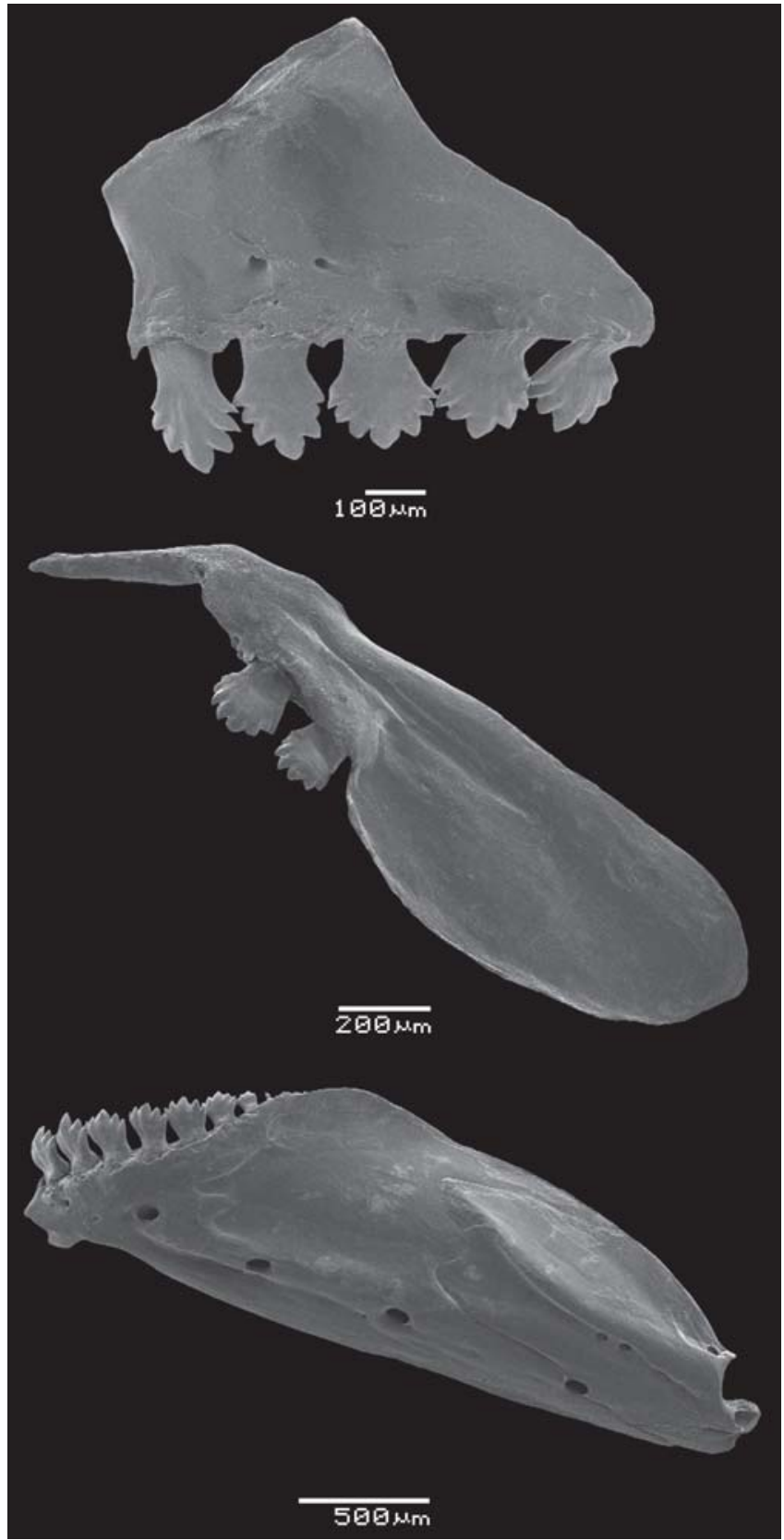

Fig 21. Dentition of Odontostilbe nareuda, FMNH 106433, male $31.6 \mathrm{~mm}$ SL. SEM photograph of left side premaxilla (top), maxilla (middle), and dentary (bottom).

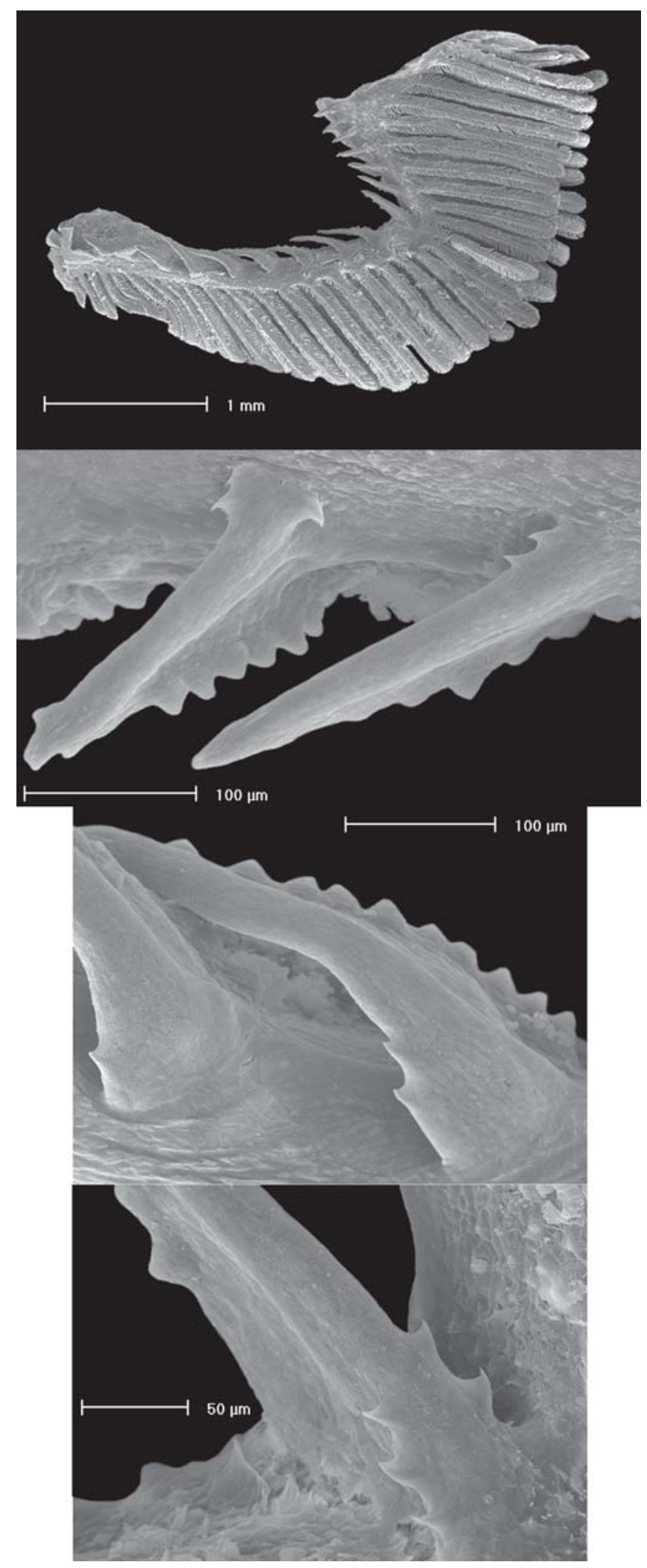

Fig. 22. First gill arch of Odontostilbe nareuda, FMNH 106433 , unsexed $29.2 \mathrm{~mm}$ SL. SEM photographs of the left side gill arch (top), in detail gill rakers on upper branchial branch (middle), and gill rakers on lower branchial branch (bottom). Lateral view. 
Table 3. Morphometrics of Odontostilbe nareuda n. sp. (holotype CBF 09621, paratypes 5 of FMNH 106433, 1 of MZUSP 87759, 5 of MZUSP 87760, non-paratypes 3 of MNHN 1989-1465, 1 ofFMNH 106428, 1 of FMNH 106430, and 1 FMNH 116462).

\begin{tabular}{|c|c|c|c|c|c|c|c|c|c|}
\hline & \multicolumn{5}{|c|}{ Males } & \multicolumn{4}{|c|}{ Unsexed } \\
\hline & Holotype & $\mathrm{n}$ & Low & High & Mean & $\mathrm{n}$ & Low & High & Mean \\
\hline Standard length & 33.1 & 3 & 29.4 & 31.6 & 30.8 & 13 & 26.7 & 37.9 & 30.3 \\
\hline \multicolumn{10}{|l|}{ Percents of standard length } \\
\hline head length & 25.1 & 3 & 25.0 & 25.9 & 25.3 & 13 & 24.1 & 26.1 & 25.4 \\
\hline snout-anal fin origin & 59.5 & 3 & 58.9 & 60.8 & 60.0 & 13 & 59.9 & 62.0 & 60.7 \\
\hline snout-dorsal fin origin & 49.5 & 3 & 50.0 & 51.0 & 50.5 & 13 & 49.1 & 52.2 & 50.6 \\
\hline snout-pelvic fin origin & 43.5 & 3 & 43.9 & 44.9 & 44.3 & 13 & 42.8 & 45.9 & 44.2 \\
\hline dorsal-fin base & 13.6 & 3 & 13.6 & 15.0 & 14.2 & 13 & 13.5 & 15.6 & 14.2 \\
\hline anal-fin base & 31.1 & 3 & 31.3 & 31.8 & 31.6 & 13 & 30.6 & 32.8 & 31.8 \\
\hline caudal peduncle length & 13.0 & 3 & 12.4 & 13.0 & 12.7 & 13 & 11.3 & 13.1 & 12.3 \\
\hline caudal peduncle depth & 11.2 & 3 & 10.2 & 10.9 & 10.6 & 13 & 9.4 & 11.5 & 10.5 \\
\hline depth at dorsal-fin origin & 30.5 & 3 & 30.4 & 31.3 & 31.0 & 13 & 30.3 & 34.8 & 31.9 \\
\hline dorsal-fin length & 30.8 & 2 & 30.9 & 33.0 & 31.9 & 7 & 30.4 & 32.4 & 31.4 \\
\hline pelvic-fin length & 18.1 & 3 & 17.8 & 18.4 & 18.1 & 13 & 16.5 & 18.0 & 17.2 \\
\hline pectoral-fin length & 22.1 & 3 & 21.3 & 22.4 & 22.0 & 13 & 18.7 & 21.1 & 20.4 \\
\hline snout-pectoral-fin origin & 25.1 & 3 & 25.3 & 25.9 & 25.5 & 13 & 24.1 & 26.1 & 25.7 \\
\hline \multicolumn{10}{|l|}{ Percents of head length } \\
\hline snout length & 22.9 & 3 & 22.8 & 23.7 & 23.1 & 13 & 19.8 & 21.6 & 20.6 \\
\hline upper jaw length & 27.7 & 3 & 27.8 & 29.1 & 28.6 & 13 & 25.7 & 29.6 & 27.1 \\
\hline horizontal eye diameter & 38.6 & 3 & 40.5 & 42.1 & 41.0 & 13 & 37.6 & 41.4 & 39.7 \\
\hline least interorbital width & 31.3 & 3 & 31.6 & 31.6 & 31.6 & 13 & 29.6 & 33.3 & 31.1 \\
\hline
\end{tabular}

anterior branched rays longer than posterior rays. Pectoralfin rays i(17), 9(1), 10(9), or 11(7). Unbranched pectoral-fin ray reaching or not reaching pelvic-fin origin, extending beyond pelvic-fin origin in mature males. Pelvic-fin rays i(20), $6(1)$, or 7(19). No evident elongation of unbranched dorsal or pelvic-fin rays in males. Lateral skin border of unbranched pectoral-fin rays and unbranched pelvic-fin rays thickened in mature males, bearing thin laterodorsal projection of hard tissue covered with soft tissue. Principal caudal-fin rays 19(20). Procurrent caudal-fin rays: dorsal 11(7), 12(8), or 13(2); ventral 9(7) or 10(10). Sometimes anterior ventral procurrent caudal-fin rays modified, distally bifurcated. Caudal-fin ray flaps ventrally on $4^{\text {th }}-7^{\text {th }}$ rays of upper lobe, and dorsally on $14^{\text {th }}-15^{\text {th }}$ rays of lower lobe. Adipose-fin at vertical through last analfin ray insertion.

Holotype and paratype males of FMNH 106433 are unique, all having not totally developed hooks. Males with acute, retrorse hooks on posterior margin of pelvic and anal-fin rays. One or two paired or unpaired hooks per segment of lepidotrichia on last unbranched anal-fin ray, and $1^{\text {st }}$ to $9^{\text {th }}$ anal-fin branched rays, positioned at middistal length of rays. One or two unpaired hooks per segment of lepidotrichia along almost entire length of $1^{\text {st }}$ to $7^{\text {th }}$ branched pelvic-fin rays, and reaching tip of fin rays (except on $1^{\text {st }}$ branched pelvic-fin ray, on midlenght portion).

Scales cycloid; lateral line complete $35(1)$ or $\mathbf{3 6}(6)$; predorsal row $10(6)$ or 11(10); scale rows between lateral line and dorsal-fin origin 5(7) or 6(6); scale rows between lateral line and anal-fin origin 4(15), scale near pelvic-fin origin usually smaller than others); scale rows around caudal peduncle 14(7). Triangular modified scale on pelvic-fin base extends posteriorly covering 1-3 scales. Scales on anal-fin base 6-7.

Cleared and stained specimens (2): supraneurals 4(1) or
5(1); precaudal vertebrae, 16(2); caudal vertebrae 19(2). Gill rakers (counted in 15 alcohol specimens, and 2 c\&s), upper $5(3)$ or 6(13); lower 10(3), 11(7), or 12(6) (1-2 on hypobranchial). Upper gill rakers with 1-3 recurved denticles on anterolateral border, and none or 1 similar denticle on posterolateral border; lower gill rakers with none to 3 recurved denticles on anterolateral border (1-4 anteriormost lower gill rakers with none or 1 denticle on posterolateral border); posteriormost lower gill raker with 3 denticles on anterolateral border, and 12 similar denticles on posterolateral border (Fig. 22). All denticulation mainly on basal portion of gill rakers.

Color in alcohol. General ground body color brownish or pale yellow. Dorsal portion of body dark from head to caudal peduncle; dark chromatophores mostly on scale borders, forming reticulated pattern. Pigmented scales not extending laterally on body, no distinct dark chromatophores on pseudotympanum area. Dorsal fin entirely with dark chromatophores scattered along all fin rays, more densely along $1^{\text {st }}$ and $2^{\text {nd }}$ unbranched dorsal-fin rays. Pectoral and pelvic fins with scattered dark chromatophores, more numerous on anteriormost portions of fins. Holotype with pelvic fins hyaline. Anal fin mostly pigmented, dark chromatophores spread on all fin rays, except at tips of last unbranched fin ray and $1^{\text {st }}$ branched fin ray. Adipose fin hyaline. Caudal fin almost entirely covered with diffuse dark chromatophores along fin rays, clear areas on base of caudal-fin lobes just behind caudal-fin spot. Rounded black to brown spot on base of caudal fin, reaching upper and lower border of peduncle, usually lighter near ventral border, sometimes extending little on proximal portion of $7^{\text {th }}$ to $12^{\text {th }}$ central caudal-fin rays.

Numerous chromatophores on snout, as well as upper and lower lips (on lower lip these almost form line). Numerous 
dark chromatophores on anteriormost portion of maxilla, and $1^{\text {st }}$ infraorbital. Pigmentation on top of head on frontals and parietals, and deep-lying dark chromatophores cover brain membranes below frontals, parietals, and fontanel. Body with faint dark midlateral stripe, sometimes reduced to line along longitudinal body axis, beginning below dorsal fin, above lateral line, and extending to caudal spot. Belly pale, almost without chromatophores below lateral line, except above analfin base with 7 to 12 chevron shaped markings. Guanine on eye iris, interopercle, opercle, subopercle, isthmus, $2^{\text {nd }}$ to $4^{\text {th }}$ infraorbitals, lateral portion of parietals just behind eye, and belly. Guanine more evident in MCP 38417, and MZUSP 87760 specimens. Holotype with some guanine.

Odontostilbe nareuda seems to have fewer dark chromatophores than similar species such as $O$. fugitiva, O. dierythrura, and $O$. parecis, and another new species from río Madre de Dios (in manuscript), all of these occur in the rio Madeira basin. Except for $O$. parecis from rio Guaporé basin, the other three species were found to be sympatric with $O$. nareuda.

Sexual dimorphism. Only three males available, holotype and two paratypes, but these are not fully mature, without completely developed hooks. These males have longer pectoralfin rays in contrast with specimens with undetermined sex, statistically significant in test for coincidental regressions $\left(\mathrm{F}_{(2,276)}=28.5, \mathrm{p}<0.00\right)$ (Fig. 23). The snout profile of holotype is slightly protruded in comparison with the unsexed paratype FMNH 106433 (Fig. 19). Gill gland not found in males of $O$. nareuda. Absence of this gill gland probably explained by lack of mature males among examined specimens.

Distribution. Odontostilbe nareuda is known from the lower río Beni basin, in the ríos Nareuda and Muyumanu, of the ríos Tahuamanu-Orthon drainage that runs parallel to the río Madre de Dios, and the middle rio Madeira (Fig. 18). However, it may be widespread in the rio Madeira basin. Some specimens from the upper rio Mamoré basin were tentatively identified as $O$. nareuda. Also, three specimens from the rio Purus match the

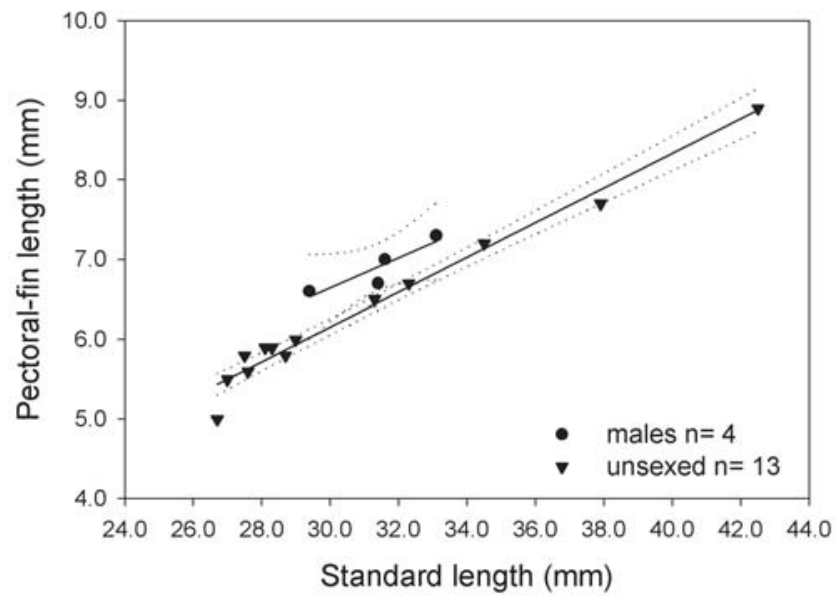

Fig. 23. Pectoral-fin length as a function of standard length for males versus unsexed specimens of Odontostilbe nareuda. larger anal-fin base diagnostic of $O$. nareuda. A somewhat similar distribution was observed for Creagrutus occidaneus that occurs in río Madre de Dios and upper rio Purus (Vari \& Harold, 2001). Further samples of these regions including mature males and females are needed to assure these distributions.

Etymology. In allusion to the type-locality, in the río Nareuda.

Ecological notes. FMNH field notes for $O$. nareuda indicate that it occurs in oxbow lakes, river or small river habitats in forest, having whitewater or turbid-white water. The bottom was sandy or muddy substrate with sticks, logs, and leaves. Nevertheless the río Nareuda is mostly a blackwater river as noted by Machado-Alllison et al. (1999a), all the locality notes of FMNH lots refer to whitewater, except FMNH 106430 which mentions clearwater of brown color. The lower río Nareuda seems to be influenced by whitewaters of the río Tahuamanu - río Orthon basin. The FMNH specimens all came from the AquaRAP expedition in the upper río Orthon basin, Bolívia. These specimens were originally identified as Cheirodon fugitiva, Odontostilbe fugitiva or Odontostilbe sp. (Chernoff et al., 1999; Sarmiento et al., 1999). Specimens identified for the AquaRAP expedition as $O$. paraguayensis, and listed as that species by Willink et al. (1999) as "believed to be" a new record for the Bolivian Amazon, actually are O. nareuda or an undescribed species of cheirodontine. Both species were collected together, being probably syntopic. MachadoAllison et al. (1999b) detailed the abundance of species regarding the field station that corresponds to FMNH lots of the holotype and some paratypes (FMNH 106433) and cited "O. paraguayensis" as the most abundant species, and "Cheirodon fugitiva" the fifth ranked, being "typically from cochas or flooded lakes".

\section{Odontostilbe parecis, new species}

Fig. 24

Holotype. INPA 24885, 1 (male 33.0 mm SL), Brazil, Mato Grosso, BR 174, Corredeira Papagaio, [near BR 364, rio Galera, upper rio Guaporé basin], Equipe Rose, V. Py-Daniel et al., 3 Oct 1984.

Paratypes. BRAZIL, MATO GROSSO: INPA 21424, $4 \mathrm{~m}$ of 8 (1 male 35.0 mm SL, 3 unsexed 29.8-36.2 mm SL), same data as holotype. INPA $21425,1 \mathrm{~m}$ of 23 (male $30.6 \mathrm{~mm} \mathrm{SL}$ ), rio Novo, BR 174, [near BR 364, rio Novo, rio Galera, upper rio Guaporé basin], Equipe Rose, V. Py-Daniel et al., 2 Oct 1984. MCP 37318, 129 (unsexed 16.7-38.0 mm SL), Nova Lacerda, rio Galera, affluent of rio Guaporé in Balneário Galera, V. Bertaco et al., 14²8'59'S 59 35'07' 'W, 12 Jul 2004. MCP 37319, 14m of 82 (5 males 30.3$39.0 \mathrm{~mm}$ SL, 1 male $32.8 \mathrm{~mm}$ SL c\&s, 4 females $33.6-41.6 \mathrm{~mm}$ SL, 1 female $36.8 \mathrm{~mm}$ SL c\&s, 3 unsexed 31.3-34.4 mm SL), Pontes e Lacerda, affluent of rio Galera about $71 \mathrm{~km}$ north of rio Guaporé, 1439'12"S 59²6’46”W, R. Reis et al., 12 Jul 2004.

Non-type material. Rio Madeira - Rio Guaporé basin, BRASIL, MATO GROSSO: MCP 38493, 45 (2 males 31.8-32.3 mm SL, 43 unsexed 15.6-38.7 mm SL), Comodoro, stream affluent of rio Novo on the road BR $174,14^{\circ} 13^{\prime} 25^{\prime \prime} \mathrm{S} 59^{\circ} 41^{\prime} 27^{\prime}$ 'W. 


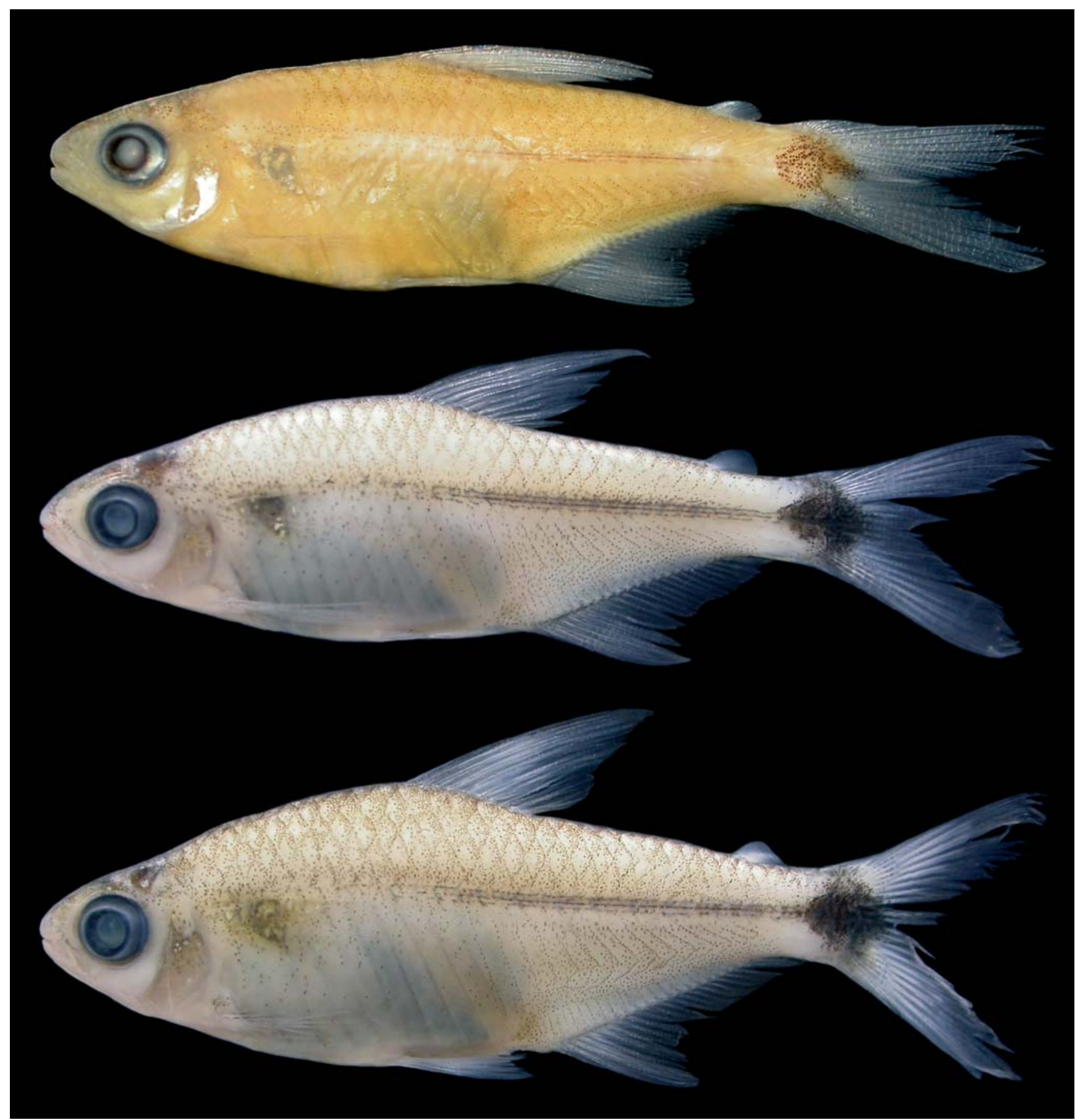

Fig. 24. Holotype of Odontostilbe parecis, INPA 24885, male $33.0 \mathrm{~mm}$ SL (top), and paratypes MCP 37319 , male 33.0 mm SL (middle), female $41.6 \mathrm{~mm}$ SL (bottom).

Diagnosis. Differs from Amazonian species of Odontostilbe by: (1) number of lower gill rakers 9-10 (vs. 11-14 in Odontostilbe fugitiva and O. dierythrura, 10-11 in O. ecuadorensis, and 10-12 in O. nareuda) (Fig. 13a-b); (2) number of branched anal-fin rays (20-21, vs. 23-26 in O. nareuda); (3) terminal mouth ( $v s$. conspicuous subterminal mouth in $O$. euspilura); (4) longer upper jaw length 28.8-32.9\% HL (vs. 23.4-30.0\% HL in O. fugitiva, Fig. 25, or vs. $23.0-29.2 \% \mathrm{HL}$ in O. ecuadorensis); and (5) larger eye in males $38.9-40.8 \% \mathrm{HL}$ diameter (vs. 28.9-38.6\% HL in O. fugitiva, Fig. 26, or vs. 33.3$38.1 \% \mathrm{HL}$ in $O$. ecuadorensis). The combination of the characters listed above distinguishes $O$. parecis from all other Odontostilbe species.

Description. Morphometric data given in Table 4. Largest male reaching $35.0 \mathrm{~mm}$ SL, and female $41.6 \mathrm{~mm}$ SL. Body elongate and compressed. Males with more elongate and compressed bodies than females. Greatest body depth at dorsal- 


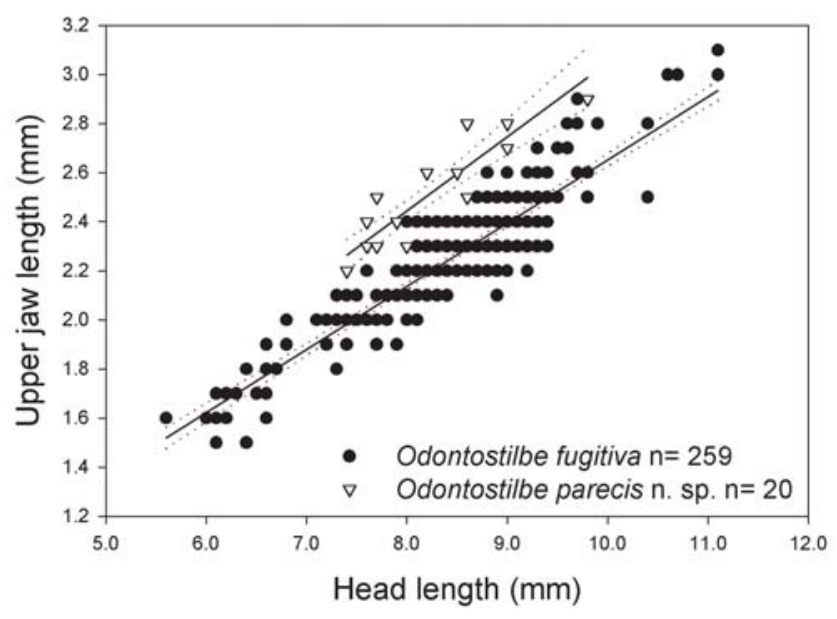

Fig. 25. Upper jaw lenght as a function of head length for males, females, and unsexed specimens of Odontostilbe fugitiva and Odontostilbe parecis.

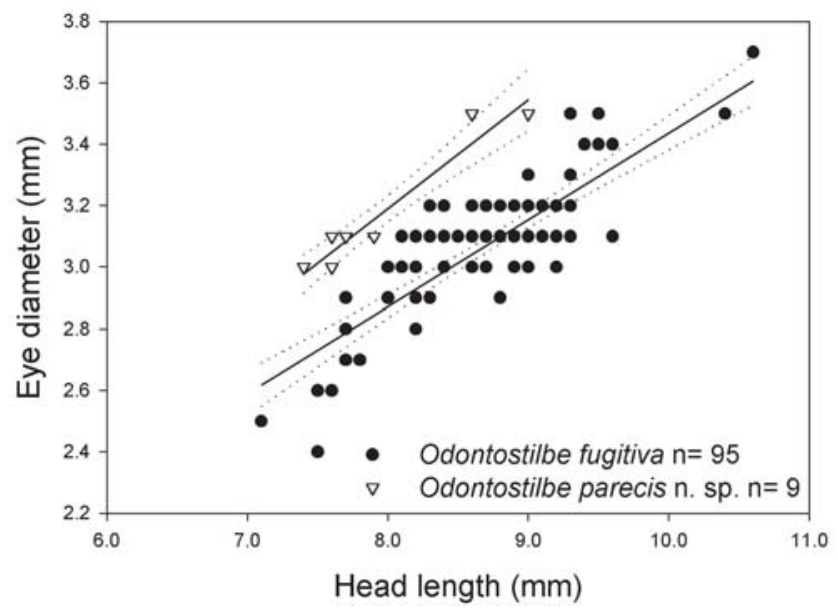

Fig. 26. Eye diameter as a function of head length for males of Odontostilbe fugitiva and Odontostilbe parecis.

fin origin. Snout blunt, larger in males. Head profile pointed, gently convex from snout to posterior tip of supraoccipital bone. Dorsal profile ascends almost straight from that point to dorsal-fin origin, sometimes with sligth depression at posterior tip of supraoccipital; from dorsal-fin origin descends almost straight to caudal peduncle. Ventral profile convex from lower jaw to anal-fin origin, and straight along anal-fin base. Caudal peduncle slightly longer than deep.

Head relatively small. Posterior margin of opercle sinusoidal with upper portion concave and lower portion convex. Mouth terminal. Maxilla short, terminating posteriorly at vertical near anterior eye border, and ending at level equal to inferior eye border, positioned at 45 degrees angle relative to longitudinal body axis. Cleared and stained specimens (2). Premaxillary teeth 5, bearing 8-10 cusps; midcentral cusp longer than lateral cusps; smaller lateral cusps of each tooth overlap cusps of adjacent teeth (Fig. 27). Premaxillary teeth juxtaposed externally to dentary teeth, leaving premaxillary tooth cusps exposed when mouth closed. Maxilla with 2-3 teeth bearing 7-9 cusps, usually decreasing cusp number to

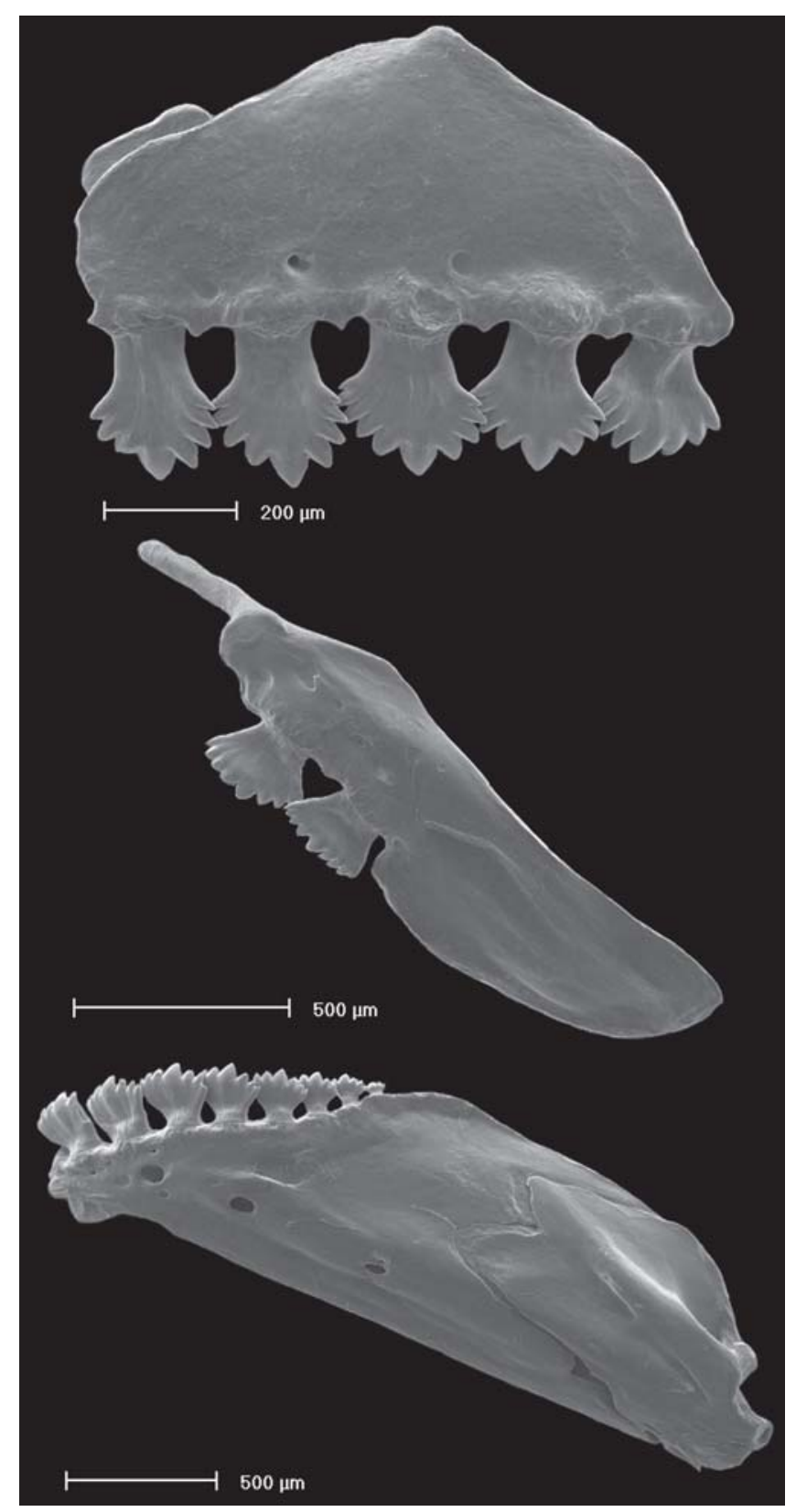

Fig. 27. Dentition of Odontostilbe parecis, MCP 37319, male $32.8 \mathrm{~mm}$ SL. SEM photograph of left side premaxilla (top), maxilla (middle), and dentary (bottom).

posterior tip of maxilla. Dentary teeth $8-9$ bearing 2-7 cusps, gradually decreasing in size posteriorly, first 6-7 teeth large with 6-7 cusps, following 2 small teeth with 2-5 cusps. Smaller cusps of all dentary teeth overlaping adjacent teeth cusps, usually not in posteriormost teeth. All dentary tooth cusps slightly recurved towards interior of mouth.

Dorsal-fin rays ii(20) or 9(20). Dorsal-fin origin slightly posterior to midlength of body, and slightly posterior to vertical through pelvic-fin origin. Anal-fin rays v(20), 19(5), 20(8), or 21(7). Anal-fin distal border concave, anterior 6-7 branched rays longest. Pectoral-fin rays: i(20), 9(1), 10(7), 11(10), or 12(2). Unbranched pectoral-fin ray short of reaching or reach- 
ing pelvic-fin origin, slightly extending beyond pelvic-fin origin in males. Pelvic-fin rays i(20), 6(1), or 7(19). Unbranched dorsal or pelvic-fin rays not elongate in males. Lateral skin border of unbranched pectoral-fin rays and unbranched pelvic-fin rays thickened in mature males, bearing thin laterodorsal projection of hard tissue covered with soft tissue. Principal caudal-fin rays 19(20). Procurrent caudal-fin rays: dorsal 10(2), 11(9), or 12(9); ventral 8(3), 9(15), or 10(2). Anterior ventral procurrent caudal-fin rays distally bifurcated or not. Caudal-fin ray flaps ventrally on $2^{\text {nd }}-8^{\text {th }}$ (mostly $\left.4^{\text {th }}-7^{\text {th }}\right)$
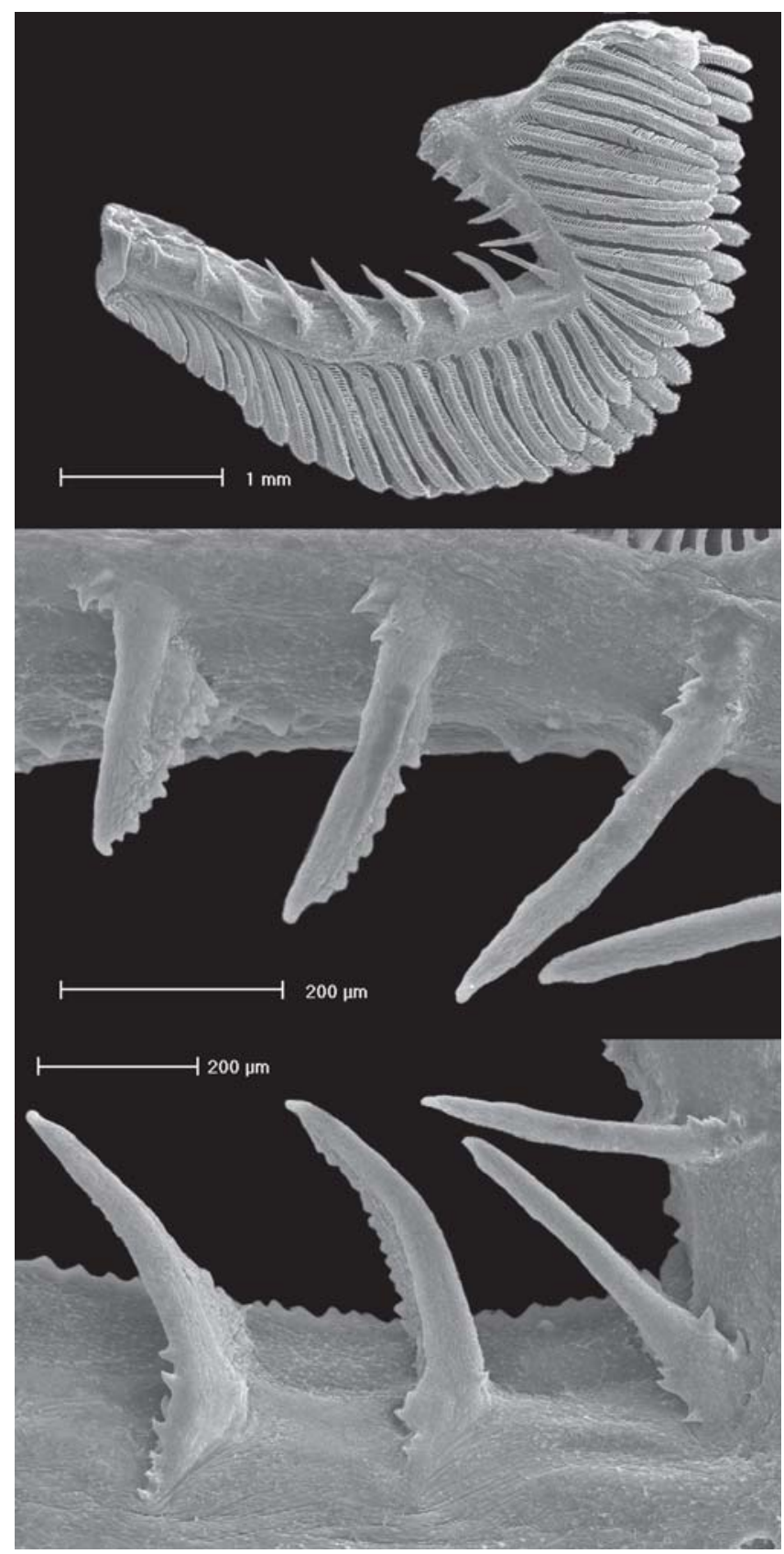

Fig. 28. First gill arch of Odontostilbe parecis, INPA 21425 , male $30.6 \mathrm{~mm}$ SL. SEM photographs of the left side gill arch (top), in detail gill rakers on upper branchial branch (middle), and gill raker on lower branchial branch (bottom). Lateral view. rays of upper lobe, and dorsally on $12^{\text {th }}-16^{\text {th }}$ (mostly $13^{\text {th }}-15^{\text {th }}$ ) rays of lower lobe. Adipose fin at vertical through last analfin ray insertion.

Males with acute, retrorse hooks on posterior margin of pelvic and anal-fin rays. One or two paired and unpaired hooks per segment of lepidotrichia, on last unbranched anal-fin ray, and $1^{\text {st }}$ to $8^{\text {th }}$ branched anal-fin rays, positioned at middistal length of rays and usually not extending to ray tip; tiny hooks can be present up to $16^{\text {th }}$ anal-fin branched ray, occurring distally on branches (up to $17^{\text {th }}$ anal-fin branched ray in holotype). One or two unpaired hooks per segment of lepidotrichia on $1^{\text {st }}$ to $7^{\text {th }}$ branched pelvic-fin rays, extending almost entirely to distal ray tip (along midlenght of $1^{\text {st }}$ branched pelvicfin ray). Few mature males available for description of hooks. Type material from INPA contains males with more developed hooks. Holotype with hooks on $2^{\text {nd }}$ to $5^{\text {th }}$ branched pelvic-fin rays. Because available males are not fully mature, this species could have typical elongation of unbranched dorsal and pelvic-fin rays present in of Odontostilbe species.

Scales cycloid; lateral line complete $35(7)$ or 37(1); predorsal row 9(2), 10(12), or 11(3); scale rows between lateral line and dorsal-fin origin 5(10) or 6(8); scale rows between lateral line and anal-fin origin $4(18)$; scale rows around caudal peduncle 14(10). Triangular modified scale on pelvic fin base extends posteriorly covering 1-2 scales (mostly 2). Scales on anal-fin base 5-7 (partially missing in holotype).

Cleared and stained specimens (2): supraneurals 4(2); precaudal vertebrae, 15(1) or 16(1); caudal vertebrae 19(2). Gill rakers (18 in alcohol, 2 c\&s), upper 5(17) or 6(3), lower $9(12)$ or 10(8) (2 on hypobranchial). Upper gill rakers with none or 1-3 recurved denticles along anterolateral border, and none to 2 similar denticles on posterolateral border; lower gill rakers with none to 5 recurved denticles on anterolateral border (1-4 anteriormost lower gill rakers with none to 2 denticles on posterolateral border); excepting posteriormost lower gill raker with 4 recurved denticles irregularly placed on lateral surface (Fig. 28). All denticulation mostly on basal portion of gill rakers.

Color in alcohol. General ground body color brownish or pale yellow. Dorsum dark from head to caudal peduncle, chromatophores mostly on scale borders forming reticulated pattern. Pigmented scales extend laterally on body below longitudinal stripe, also on pseudotympanum area. Dorsal fin with scattered chromatophores along all fin rays, more densely pigmented along $1^{\text {st }}$ and $2^{\text {nd }}$ unbranched dorsal-fin rays. Pectoral and pelvic fins with scattered dark chromatophores, more numerous on anteriormost portions of fins. Holotype with pelvic fin hyaline. Anal fin mostly pigmented with chromatophores spread on all fin rays, except at distal tips of last unbranched fin ray and 1st branched fin ray. Adipose fin hyaline. Caudal fin almost entirely covered with diffuse chromatophores along fin rays, clear areas on base of caudal-fin lobes just posterior to caudal-fin spot. Rounded black to brown spot on base of caudal fin, usually light near lower border, sometimes extending little onto proximal portion of $7^{\text {th }}$ to $12^{\text {th }}$ central caudal-fin rays. 
Numerous chromatophores on snout, upper and lower lips, anteriormost portion of maxilla and lower jaw, and $1^{\text {st }} 2^{\text {nd }}$ infraorbitals. Pigmentation on dorsal surface of head on frontals and parietals, and deep-lying dark chromatophores over brain membranes below frontals and parietals, and fontanel. Body with faint dark midlateral stripe, sometimes reduced to line, along midlongitudinal body axis, beginning posterior to or on pseudotympanum, above lateral line, reaching caudal spot. Below lateral line, ventral body faint almost without chromatophores. Pigmented area above anal-fin base forming 10 to 11 chevron-shaped markings. Guanine surrounds eye iris, interopercle, opercle, ishtmus, and most $3^{\text {rd }}$ infraorbital. Holotype with some remaining guanine, but fresher specimens of MCP without any guanine.

Sexual dimorphism. Males with anal- and pelvic-fin hooks on rays as previously described, such hooks absent in females. Gill gland (Burns \& Weitzman, 1996) present in three mature males of Odontostilbe parecis, holotype, and two paratypes (Fig. 28). Holotype of $O$. parecis with gill gland present on first gill arch, covering about 9 anterior branchial filaments. Paratype INPA 21425, a male $30.6 \mathrm{~mm}$ SL with a gland including about 7 anterior branchial filaments and paratype MCP 37319, $39.0 \mathrm{~mm}$ SL with gland including about 6 anterior branchial filaments. Principal component analysis of morphometric data of males and females plus unsexed specimens shows sexual dimorphism in general body shape (Fig. 29). Principal component 2 (PC2) grouped males and females separately. This affected strongly and negatively by caudal peduncle length, pectoral-fin length, pelvic-fin length, and snout length; and positively by depth at dorsal-fin origin. Principal component 3 (PC3) affected strongly and positively by snout length and caudal peduncle length, negatively by anal-fin base and pectoral-fin length. Males differed

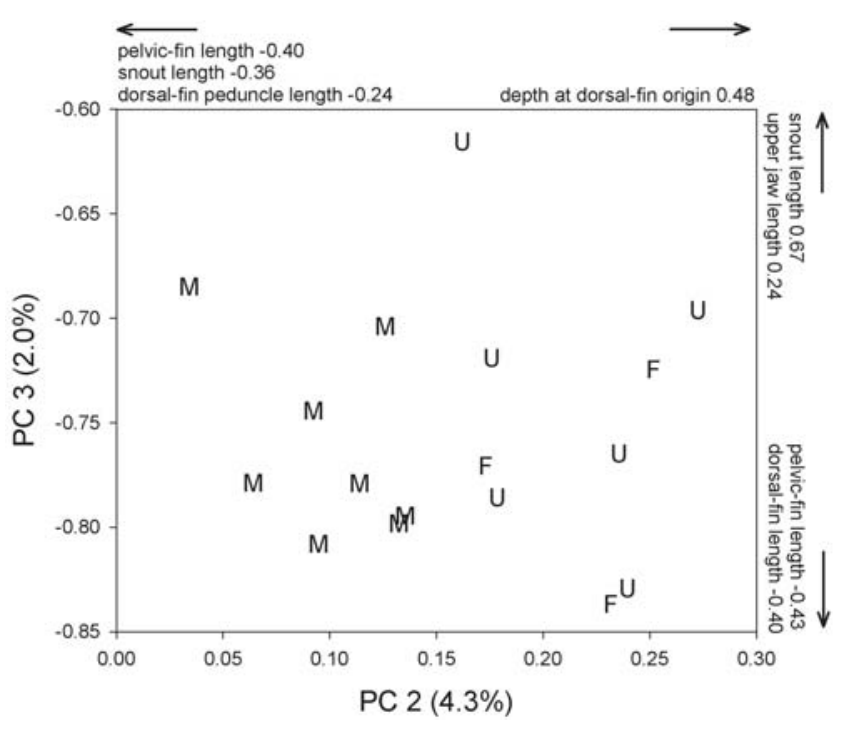

Fig. 29. Principal component analysis of the 18 morphometric data of males (M), females (F), and unsexed specimens (U) of Odontostilbe parecis. Stronger loadings on the second and third principal components (PC2, $\mathrm{PC} 3)$.

from females in all of these characters. Usually males with higher mean values for peduncle length, pectoral-fin length, pelvic-fin length, and snout length, while females and unsexed specimens have higher depth at dorsal-fin origin than males (Table 3). Unsexed specimens were not assumed to be females, because they probably also include immature males. All examined males are probably not fully mature as mentioned in description. Additional material may reinforce sexual morphometric characters described here.

Table 4. Morphometrics of Odontostilbe parecis n. sp. (holotype INPA 24885, paratypes INPA 21424, and MCP 37319).

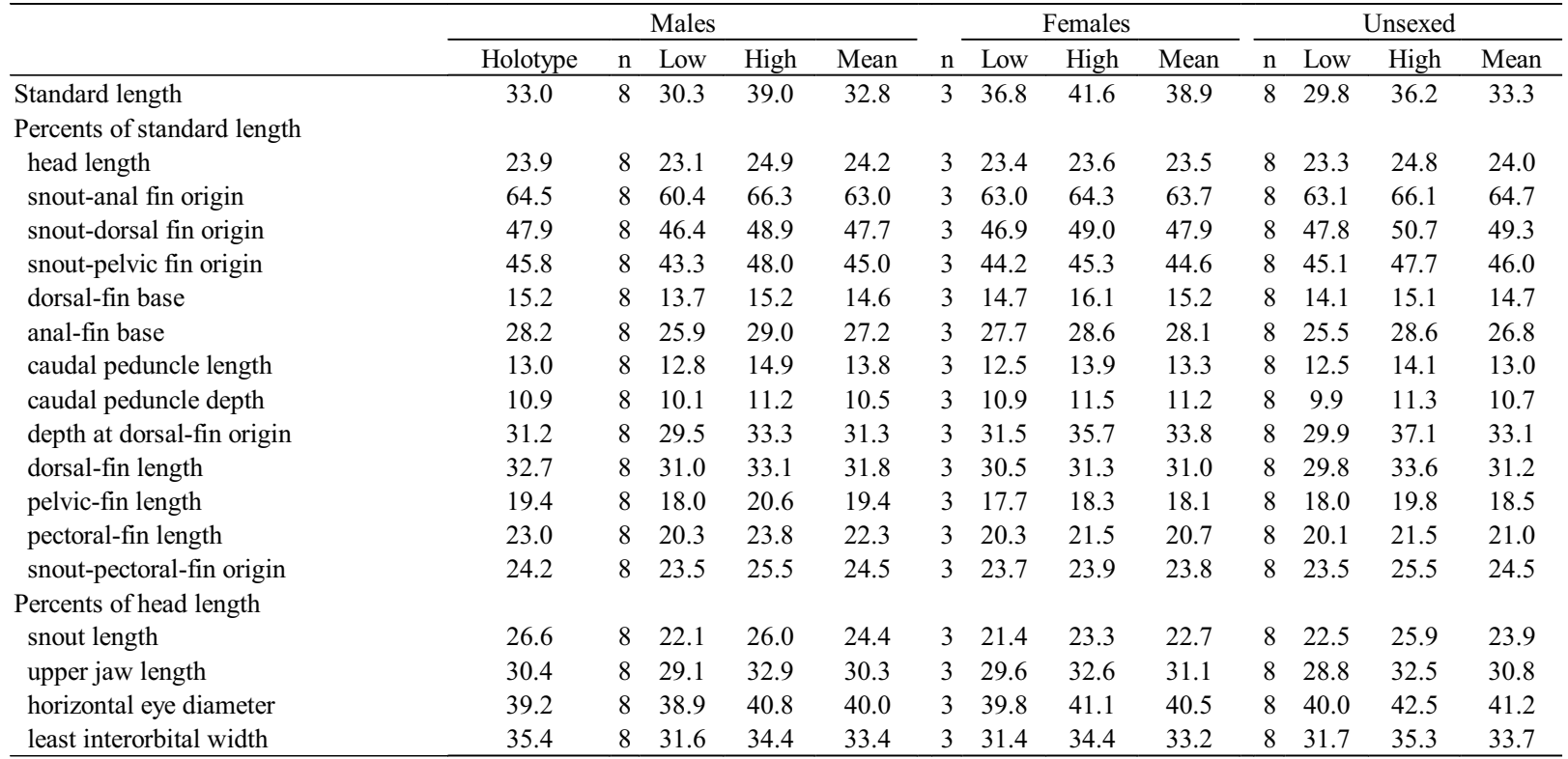


Distribution. Upper rio Guaporé drainage, rio Galera and rio Novo.

Etymology. The epithet parecis refers to the Chapada dos Parecis, a plateau situated on the east of Guaporé tributaries where the species was discovered.

Ecological notes. The Guaporé-Iténez is a clearwater rightbank tributary of the major rio Madeira (Goulding et al., 2003). Field notes record of MCP material: translucent water of quiet to medium flow, sandy bottom with pebbles, and a depth of 1$1.2 \mathrm{~m}$. This was species collected along with Serrapinnus sp.

\section{Discussion}

Previous phylogenetic diagnosis for the genus Odontostilbe among cheirodontines was based on two synapomorphies described in Malabarba (1998), and related to the elongation of the second unbranched dorsal-fin ray and the unbranched pelvic-fin ray of males. These characters were found homoplastic in "Odontostilbe" mitoptera of the Compsurini. Recognition of Odontostilbe separately from genera assigned to the tribes Cheirodontini and Compsurini was also supported by the lack in Odontostilbe species of the several synapomorphies dignosing those tribes and their included genera. These synapomorphies consist of primary and secondary sexual characters. The genera Pseudocheirodon, Prodontocharax, Aphyocheirodon, and Cheirodontops also lack specialized sexually dimorphic features present in the Compsurini and Cheirodontini and were diagnosed based on jaws and teeth modifications, absent in Odontostilbe.

The diagnosis of Odontostilbe in the present contribution follows that of Malabarba (1998), based on the analysis of two Odontostilbe species only, O. fugitiva and O. pequira, respectively the type species of the genera Odontostilbe and Holoshesthes. Holoshesthes was placed in the synonym of Odontostilbe. We found morphological diversity in Odontostilbe much larger than previously known. We recognize in Odontostilbe six species of the ten species referred to the genus by Malabarba (2003): O. fugitiva, O. dierythrura Fowler, 1940, O. microcephala Eigenmann, 1907, O. paraguayensis Eigenmann \& Kennedy, 1903, O. pequira (Steindachner, 1882), and O. roloffi Géry, 1972 (actually a synonym of $O$. euspilura, see below). This excludes the two species of Central American compsurins provisionally kept in Odontostilbe: "O." dialeptura and "O." mitoptera. Also, the generic assignment of the two nominal species described by Géry (1960) as Cheirodon (C. gracilis and C. gracilis littoris) and latter transferred to Odontostilbe by Planquette et. al. (1996), deserve a separate revision and are not included in Odontostilbe.

In a comprehensive taxonomic revision of Odontostilbe in progress by the first author, 10 additional species of cheirodontines were found related to this genus, in addition to the six species listed above and the three new species described herein. Among these 10 species, 8 are undescribed, one is Odontostilbe pulchra (Gill, 1858) [left as species inquirenda among Cheirodontinae by Malabarba (2003)], and the last one is Cheirodontops geayi Schultz, 1944, type species of Cheirodontops. Cheirodontops geayi was not previously hypothesized as related to Odontostilbe, although Böhlke (1954) pointed out that Cheirodontops Schultz, 1944 was solely distinguished from Holoshesthes Eigenmann, 1903 by the absence of teeth on the maxillary. The examination of type material of C. geayi, and an extensive revision of the species, showed that the teeth are present on the maxilla. Also it was found that the elongation of dorsal- and pelvic-fin rays in mature males that diagnoses Odontostilbe is present in Cheirodontops. Schultz (1944) observed the resemblance of teeth between Cheirodontops and Holoshesthes. Malabarba (1998) based on the phylogenetic analysis of Cheirodontinae placed Holoshesthes in synonym of Odontostilbe, arguing that the character of the presence of dentary teeth with at least five cusps, with the three central cusps larger, compressed and in a row forming a sharp cutting edge, was found to be ambiguous, and independently acquired in four cheirodontine lineages. Eigenmann (1915), and Géry (1977) used this character alone to distinguish Holoshesthes of Odontostilbe. Additional phylogenetic analysis of Odontostilbe is needed to clarify the relationships and taxonomic status of Holoshesthes and Cheirodontops.

Malabarba (2003) listed Deuterodon (Lobodeuterodon) euspilurus Fowler, 1945, described from upper río Caquetá basin, Colombia, as a junior synonym of $O$. fugitiva. According to work in progress by the senior author, O. euspilura (Fowler, 1945) is a valid species, and a senior synonym of $O$. roloffi Géry, 1972 described from upper río Napo, Ecuador. A full redescription of this species will be provided in a forthcoming paper.

Almost all the mature males of the examined Odontostilbe related species share both elongations of the unbranched dorsal- and pelvic-fin rays, excepting Odontostilbe euspilura and an undescribed species from rio Uruguay basin that lack the elongation of the second unbranched dorsal-fin ray. Two other undescribed species from upper rio Paraná basin lack both elongations, of unbranched dorsal- and pelvic-fin rays, but there are few mature males available of them. Odontostilbe pulchra has a slight elongation of the second unbranched dorsal-fin ray only in some specimens, but has the unbranched pelvic-fin ray elongate.

A reevaluation of the diagnosis of Odontostilbe is still needed because the discovery of several new species not previously used in a phylogenetic analysis of the genus by Malabarba (1998). The discovery of new data regarding Cheirodontops geayi indicating that it shares characters diagnosing Odontostilbe (elongation of the dorsal- and pelvicfin rays) requires a reanalysis of the phylogeny of these genera of the Cheirodontinae. Also, such an analysis should include Lobodeuterodon (its type species) and Holoshesthes, apparent junior synonyms of Odontostilbe. 


\section{Acknowledgements}

We thank the following persons for the loan of specimens: S. Schaefer (AMNH), J. Lundberg, M. Sabaj, and M. Littmann (ANSP), Soraya Barrera (CBF), J. Fong, D. Catania, T. Iwamoto (CAS), M. Westneat, M. Rogers, B. Chernoff (FMNH), M. Retzer (INHS), L. R. Py-Daniel, L. M. Souza, M. Brasil, L. T. C. Serrão (INPA), A. Bentley (KU), R. E. Reis, C. A. S. Lucena, M. S. Lucena (MCP), R. Barriga, (MEPN), Hernán Ortega (MUSM 27501), S. Müller, C. Weber (MHNG), P. Pruvot (MNHN); W. B. Wosiacki, H. Higuchi (MPEG), J. L. Figueiredo, M. de Pinna, O. Oyakawa (MZUSP); S. O. Kullander, E. Åhlander, (NRM); R. Winterbottom, E. Holm (ROM); W. Crampton, J. Albert (UF); R. Souza-Lima, P. A. Buckup (MNRJ); S. H. Weitzman, R. P. Vari, L. Palmer, S. Raredon $(O$. caquetae photo) (USNM). Special thanks to C. Cox Fernandes, J. Lundberg during a visit to ANSP, and S. H. Weitzman for a visit to Smithsonian Institution (Tropical Fish Hobbyist fund) and for the helpful review of manuscript. We also are greatful to an anonymous reviewer. D. Stewart and R. Barriga provided invaluable specimens from Ecuador. W. Crampton and R. Reis provided the color photo of $O$. fugitiva of Ucamara project. F. Carvajal and F. Tejerina-Garro loaned material that helped with distribution. M. S. Lucena helped with MNHN loan, and V. Bertaco with MHNG loan. Thanks to J. Wingert, T. Carvalho, and T. Salatino for MCP cataloguing, and A. Charcansky for histological analysis. R. L. Pijnenburg checked the danish translation. Some the $O$. parecis material was caught during Transcontinental Expedition, supported by the All Catfish Species Inventory project. SEM photographs were taken at "Centro de Microscopia e Microanálises" - PUCRS and "Centro de Microscopia Eletrônica" - UFRGS.

\section{Literature Cited}

Böhlke, E. B. 1984. Catalog of the type specimens in the ichthyological collection of the Academy of Natural Sciences of Philadelphia. Philadelphia. Academy of the Natural Sciences of Philadelphia. 246p. Special Publication, 14.

Böhlke, J. E. 1954. Studies on the phylogeny and systematics of fishes of the family Characidae. Ph.D. Dissertation Series Publication no. 9477. Stanford University. University Microfilms, Ann Arbor, Michigan, 209p.

Burns, J. R. \& S. H. Weitzman. 1996. Novel gill-derived gland in the male swordtail characin, Corynopoma riisei (Teleostei: Characidae: Glandulocaudinae). Copeia, 1996(3): 627-633.

Chao, N. L. 2001. The fishery, diversity, and conservation of ornamental fishes in the Rio Negro Basin, Brazil - a review of the Project Piaba (1989-99). Pp. 161-204. In: Chao N. L., P. Petry, G. Prang, L. Sonneschien \& M. Tlusty (Eds.). Conservation and management of ornamental fish resources of the Rio Negro Basin, Amazonia, Brazil - Project Piaba. EDUA, Manaus, 310p.

Chernoff, B., P. W. Willink, J. Sarmiento, A. Machado-Allison, N. Menezes \& H. Ortega. 1999. Geographic and macrohabitat partitioning of fishes in hte Tahuamanu-Manuripi region, Upper Río Orthon Basin, Bolivia. Pp. 51-67. In: Chernoff, B. \& P. W. Willink (Eds.). A biological assessment of the aquatic ecosystems of the Upper Río Orthon basin, Pando, Bolivia. Bulletin of the Biological Assessment 15. Conservation International, Washington, DC, $145 \mathrm{p}$.

Cope, E. D. 1870. Contribution to the ichthyology of the Marañon. Proceedings of the American Philosophical Society, 11: 559-570.

Eigenmann, C. H. 1910. Catalog of the freshwater fishes of Tropical south-temperate America. Reports of the Princeton University Expeditions to Patagonia, 1896-1899. Princeton University \& Stuttgart, 3(4): 375-511.

Eigenmann, C. H. 1915. The Cheirodontinae, a subfamily of minute characid fishes of South America. Memoirs of the Carnegie Museum, 7(1): 1-99, pls. 1-17.

Eigenmann, C. H. \& W. R. Allen. 1942. Fishes of Western South America. I. The Intercordilleran and Amazonian lowlands of Peru. II. The high pampas of Peru, Bolivia and northern Chile. With a revision of the Peruvian Gymnotidae and of the genus Orestias. University of Kentucky, Lexington: I-XVI + 494p.

Eigenmann, C. H. \& R. S. Eigenmann, 1892. A catalogue of the fresh-water fishes of South America. Proceedings of the United States National Museum, 14: 1-81.

Eigenmann, C. H. \& C. H. Kennedy. 1903. On a collection of fishes from Paraguay, with a synopsis of the American genera of Cichlids. Proceedings of the Academy of Natural Sciences of Philadelphia, 55(2): 497-537.

Eigenmann, C. H. \& F. Ogle. 1907. An annotated list of Characin fishes in the United States National Museum and the Museum of Indiana University, with descriptions of new species. Proceedings of the United States National Museum, 33(1558): 1-36.

Fink, W. L. \& S. H. Weitzman. 1974. The so-called Cheirodontin fishes of Central America with descriptions of two new species (Pisces: Characidae). Smithsonian Contributions to Zoology, 172: $1-46$

Fowler, H. W. 1906. Further knowledge of some heterognathous fishes. Part. I. Proceedings of the Academy of Natural Sciences. Philadelphia: 293-351.

Fowler, H. W. 1913. Fishes from the Madeira river, Brazil. Proceedings of the Academy of Natural Sciences of Philadelphia, 65(3): 517-579.

Fowler, H. W. 1940. Zoological results of the second Bolivian Expedition for the Academy of Natural Sciences of Philadelphia, 1936-1937. Part. 1 - The fishes. Proceedings of the Academy of Natural Sciences of Philadelphia, 92(3): 43-103.

Fowler, H. W. 1943. A collection of fresh-water fishes from Colombia, obtained chiefly by brother Nicéforo Maria. Proceedings of the Academy of Natural Sciences of Philadelphia, 95: 223-266.

Fowler, H. W. 1945a. Los Peces del Peru: Catálogo Sistemático de los peces que habitam en aguas peruanas. Museo de Historia Natural Javier Prado/Universidade Nacional Mayor de San Marcos, Lima, 298p.

Fowler, H. W. 1945b. Colombian zoological survey. Pt. I. The freshwater fishes obtained in 1945. Proceedings of the Academy of Natural Sciences of Philadelphia, 97: 93-135.

Fowler, H. W. 1948. Os peixes de água doce do Brasil. Arquivos de Zoologia do Estado de São Paulo, São Paulo, 6: 1-204.

Galacatos, K., D. J. Stewart \& M. Ibarra. 1996. Fish community patterns of lagoons and associated tributaries in the Ecuadorian Amazon. Copeia, 1996(4): 875-894.

Géry, J. 1960. Contributions to the study of the characoid fishes no.6. New Cheirodontinae from French Guiana. Senckenbergiana Biologica, 41(1/2): 15-39. 
Géry, J. 1964. Poissons characoïdes de l'Amazonie péruvienne (Résultats scientifiques de l'expédition Amazone-Ucayali du Dr. K. H. Lüling 1959/1960). Beitrage Zur Neotropischen Fauna, 4(1): 1-44.

Géry, J. 1972a. Corrected and supplemented descriptions of certain Characoid fishes described by Henry W. Fowler, with revisions of several of their genera. Studies on the Neotropical Fauna, 7: 1-35.

Géry, J. 1972b. Contribution à l'étude de poissons characoïdes de l'Équateur. Avec une révision du genre Pseudochalceus et la descrition d'un nouveau genre endémique du Rio Cauca in Colombie. Acta Humboldtiana, Serie Geologica, Paleontologica et Biologica, 2: 1-110.

Géry, J. 1977. Characoids of the world. T.F.H. Publications, Neptune City, 672p.

Gill, T. 1858. Synopsis of the fresh water fishes of the western portion of the Island of Trinidad, W. I. Annals of Lyceum of Natural History of New York, 6: 363-430.

Gonçalves, T. K., M. A. Azevedo, L. R. Malabarba \& C. B. Fialho. 2005. Reproductive biology and development of sexually dimorphic structures in Aphyocharax anisitsi (Ostariophysi: Characidae). Neotropical Ichthyology, 3(3): 433-438.

Goulding, M., M. L. Carvalho \& E. G. Ferreira. 1988. Rio Negro, rich life in poor water: Amazonian diversity and foodchain ecology as seen through fish communities, SPB Academic Publishing, The Hague, 200p.

Goulding, M., R. Barthem \& E. Ferreira. 2003. The Smithsonian Atlas of the Amazon. Smithsonian Institution, Washington D.C., 255p.

International Comission on Zoological Nomenclature. 1999. International Code of Zoological Nomenclature. The Natural History Museum, fourth edition, London, 306p.

Johnson, R. A. \& D. W. Wichern. 1998. Applied multivariate statistical analysis. $4^{\text {th }}$ ed. Prentice-Hall, New Jersey, 816p.

Lowe-McConnell, 1991. Natural history of fishes in Araguaia and Xingu Amazonian tributaries, Serra do Roncador, Mato Grosso, Brazil. Ichthyological Exploration of Freshwaters, 2(1): 63-82.

Lütken, C. 1875. Ichthyolographiske Bidrag. III. Nogle nye eller mindre fuldstændigt kjendte, mellem- eller sydamerikanske Karpelax (Characiner). Videnskabelige Meddelelsel fra den naturhistoriske Forening i Kjöbenhavn 1874, (12-16): 220-240.

Machado-Allison, A., J. Sarmiento, P. W. Willink, N. Menezes, H. Ortega \& S. Barrera. 1999a. Diversity and abundance of fishes and habitats in the Río Tahuamanu and Río Manuripi Basins. Pp. 47-50. In: Chernoff, B. \& P. W. Willink (Eds.). A biological assessment of the aquatic ecosystems of the Upper Río Orthon basin, Pando, Bolivia. Bulletin of the Biological Assessment 15. Conservation International, Washington, DC, 145p.

Machado-Allison, A., J. Sarmiento , N. Menezes, H. Ortega, S. Barrera, T. M. Bert, B. Chernoff \& P. W. Willink. 1999b. Description of ichthyological field stations sampled during the AquaRAP expedition to Pando, Bolivia in September 1996. Pp. 114-145. In: Chernoff, B. \& P. W. Willink (Eds.). A biological assessment of the aquatic ecosystems of the Upper Río Orthon basin, Pando, Bolivia. Bulletin of the Biological Assessment 15. Conservation International, Washington, DC, 145p.

Malabarba, L. R. 1998. Monophyly of the Cheirodontinae, characters and majors clades (Ostariophysi: Characidae). Pp. 193-233. In: Malabarba, L. R, R. E. Reis, R. P. Vari, Z. M. S. Lucena \& C. A. S. Lucena (Eds.). Phylogeny and Classification of Neotropical Fishes. Edipucrs, Porto Alegre, 603p.

Malabarba, L. R. 2003. Subfamily Cheirodontinae (Characins, tetras). Pp. 215-221. In: R. E. Reis; S. O. Kullander \& C. J. Ferraris (Eds.). Check list of the freshwater fishes of South and
Central America. Edipucrs, Porto Alegre, 729p.

Malabarba, L. R. \& F. C. T., Lima \& S. H. Weitzman. 2004. A new species of Kolpotocheirodon (Teleostei: Characidae: Cheirodontinae: Compsurini) from Bahia, northeastern Brazil, with a new diagnosis of the genus. Proceedings of the Biological Society of Washington, 117(3): 317-329.

Malabarba, L. R. \& S. H. Weitzman. 1999. A new genus and species of South American fishes (Teleostei: Characidae: Cheirodontinae) with a derived caudal fin, including comments about inseminating cheirodontines. Proceedings of the Biological Society of Washington, 112(2): 410-432.

Malabarba, L. R. \& S. H. Weitzman. 2000. A new genus and species of inseminating (Teleostei: Characidae: Cheirodontinae: Compsurini) from South America with uniquely derived caudal-fin dermal papillae. Proceedings of the Biological Society of Washington, 113(1): 269-283.

Ortega, H. \& R. P. Vari. 1986. Annotated checkist of the freshwater fishes of Peru. Smithsonian Contributions of Zoololy, 437: 1-25.

Pearson, N. E. 1924. The fishes of the eastern slope of the Andes. I. The fishes of the rio Beni basin, Bolivia, collected by the Mulford expedition. Indiana University Studies, 11(64): 1-58, pls. 1-12.

Petry, P., P. B. Bayley \& D. F. Markle. 2003. Relationships between fish assemblages, macrophytes and environmental gradients in the Amazon River floodplain. Journal of Fish Biology, 63: 547-579.

Planquette, P., P. Keith \& P.-Y. Le Bail. 1996. Atlas des poissons d'eau douce de Guyane (Tome 1). Collection du Patrimoine Naturel, vol. 22. IEGB - MNHN, INRA, CSP, Muséum National d'Historie Naturelle, Ministère de l'Environnement, Paris, 429p.

Sánchez-Botero, J. I. \& C. A. R. M. Araújo-Lima. 2001. As macrófitas aquáticas como berçário para a ictiofauna da várzea do rio Amazonas. Acta Amazônica, 31(3): 437-447.

Sánchez-Botero, J. I., M. L. Farias, M. T. Piedade \& D. S. Garcez. 2003. Ictiofauna associada às macrófitas aquáticas Eichhornia azurea (SW.) Kunth. e Eichhornia crassipes (Mart.) Solms. no lago Camaleão, Amazônia Central, Brasil. Acta Scientiarum. Biological Sciences, 25(2): 369-375.

Sarmiento J., B. Chernoff, S. Barrera, A. Machado-Allison, N. Menezes \& H. Ortega. 1999. Fishes collected during AquaRAP expedition to Pando, Bolivia in September 1996. Pp. 87-95. In: Chernoff, B. \& P. W. Willink (Eds.). A biological assessment of the aquatic ecosystems of the Upper Río Orthon basin, Pando, Bolivia. Bulletin of the Biological Assessment 15. Conservation International, Washington, DC, 145p.

Saul, W. G. 1975. An ecological study of fishes at a site in upper Amazonian Ecuador. Proceedings of the Academy of Sciences of Philadelphia, 127(12): 93-134.

Schultz, L. P. 1944. The fishes of the family Characinidae from Venezuela, with descriptions of seventeen new forms. Proceedings of the United States National Museum, 95(3181): 235-267.

Souza, G. S. 1998. Introdução aos modelos de regressão linear e não-linear. Embrapa-SPI Embrapa-SEA, Brasília, 505p.

Steindachner, F. 1882a. Anzeiger der Kaiserlichen Akademie der Wissenschaften. Mathematisch - Naturwissenschaftliche Classe, 19: 175-180.

Steindachner, F. 1882b. Beitrage zur Kenntniss der flussfische Sudamerika's (IV). I. Bericht über eine Sammlung von Fischen aus dem Huallaga in dem Besitze des k. zoologischen Museums in Dresden (p. 1-16). Denkschriften der Kaiserlichen Akademie der Wissenchalften, 46: 1-44.

Stewart, D. J., M. Ibarra \& R. Barriga-Salazar. 2002. Comparison of deep-river and adjacent sandy-beach fish assemblages in the Napo River Basin, eastern Ecuador. Copeia, 2002(2): 333-343. 
Strauss, R. E. 1985. Evolutionary allometry and variation in body form in the South American catfish genus Corydoras (Callichthyidae). Systematic Zoology, 34: 381-396

Taylor, W. R. \& G. C. Van Dyke. 1985. Revised procedures for staining and clearing small fishes and other vertebrates for bone and cartilage study. Cybium, 9(2): 107-119.

Ulrey, A. B. 1895. The South American Characinidae collected by Charles Frederick Hartt. Annals of the New York Academy of Sciences, 8: 258-300.

Uj, A. 1987. Les Cheirodontinae (Characidae, Ostariophysi) du Paraguai. Revue Suisse de Zoologie, 94(1): 9-175.

Vari, R. P. \& J. C. Howe. 1991. Catalog of type specimens of recent fishes in the National Museum of Natural History, Smithsonian Institution, 1: Characiformes (Teleostei: Ostariophysi). Smithsonian Contributions to Zoology, 517: 1-52.

Vari, R. P. \& A. S. Harold. 2001. Phylogenetic study of the Neotropical fish genera Creagrutus Günther and Piabina Reinhardt (Teleostei: Ostariophysi: Characiformes), with a revision of the Cis-Andean species. Smithsonian Contributions to Zoology, 613: 1-239.
Willink, P. W., J. Sarmiento \& B. Chernoff. 1999. Comparative list of fishes reported from the Bolivian Amazon. Pp. 96-113. In: Chernoff, B. \& P. W. Willink (eds). A biological assessment of the aquatic ecosystems of the Upper Río Orthon basin, Pando, Bolivia. Bulletin of the Biological Assessment 15. Conservation International, Washington, DC, 145p.

Zar, J. 1996. Biostatistical analysis. $3^{\text {rd }}$ edition. Prentice-Hall, New Jersey, 121p.

Received September 2005 Accepted May 2006 